\title{
Religious Exemptions to Title IX
}

\author{
Kif Augustine-Adams*
}

\section{INTRODUCTION}

More than forty years after the passage of Title IX, the score is 285 to 0 , religious exemptions recognized versus those denied. ${ }^{1}$ Prior to the Human Rights Campaign's release of a report in December 2015, relatively few knew that religious exemptions to Title IX even existed. ${ }^{2}$ Although religious exemptions to Title IX and its implementing regulations at 34 C.F.R. $\S 106.12$, began in 1975 with the fanfare and publicity of congressional hearings, investigative journalism, and university protest, over time the process ceased to be public. Over its forty-year history, documented religious exemptions to Title IX largely took place in the dark, in private administrative processes rarely made public, under unpublished or obscure agency standards and policies. The parameters of religious exemptions to Title IX have never been litigated in court or subjected to judicial review. ${ }^{3}$ Virtually no scholarship exists

* Charles E. Jones Professor of Law, J. Reuben Clark Law School, Brigham Young University. adamsk@law.byu.edu. JD, Harvard Law School; BA, Brigham Young University. Portions of this article were presented at the 2016 Nootbaar Institute Conference "Doing Justice Without Doing Harm" at Pepperdine University Law School, as part of a Law \& Religion Panel at the 2016 Law \& Society Annual Meeting, and to students in my Feminist Legal Theory course. For helpful comments and criticisms, I especially thank Stirling Adams, Frederick Mark Gedicks, M. Christian Green, Mark C. Modak-Truran, Jenna Reinbold, Paul Stancil, and Robin Fretwell Wilson. Mara Teague Lemesany provided excellent research assistance.

1. The number 285 is current as of the institutions listed on OCR's September 15, 2016 update to its webpage. See Office for Civil Rights, Institutions Currently Holding Religious Exemption, U.S DEP'T EDUC. (Sept. 15, 2016), www2.ed.gov/about/offices/list/ocr/docs/t9-relexempt/rel-exempt-approved-and-pending.xlsx. While the spreadsheet on the OCR website lists 245 institutions that have claimed exemption, my count of 285 includes the multiple times that an institution has claimed exemptions. A number of institutions are repeat players. The number is likely to increase as the Department of Education's Office for Civil Rights considers religious exemption claims pending as of September 15, 2016 and educational institutions make new claims, particularly regarding transgender and homosexuality. $I d$.

2. Sarah Warbelow \& Remington Gregg, human Rights Campaign, Hidden DiscriminATION: TITLE IX RELIGIOUS EXEMPTIONS PUTting LGBT STUDENTS AT RISK (2015), http://hrc-assets.s3-website-us-east-

1.amazonaws.com//files/assets/resources/Title_IX_Exemptions_Report.pdf.

3. The plaintiff in Grove City College v. Bell, 465 U.S. 555 (1984), superseded by statute, Civil Rights Restoration Act of 1987, Pub. L. No. 100-259, 102 Stat. 28 (1988), could have raised 
on the subject, ${ }^{4}$ even within the abundant and well-developed recent theoretical work on broader questions of religious exemption. ${ }^{5}$

As the 285 to 0 score reflects, however, the agency standards and policies, as well as Title IX itself, are highly deferential to the educational institutions claiming religious exemptions. That deference underscores the need for publicity regarding the processes and policies that the Office for Civil Rights at the Department of Education employs in its execution of religious exemptions to Title IX. Through an excavation of the historical records-internal administrative agency communications, policy guidance memoranda, congressional testimony,

the question of religious exemption, but did not. See, e.g., Brief for Respondents at n.55, Grove City

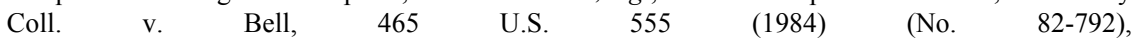
http://www.justice.gov/sites/default/files/osg/briefs/1983/01/01/sg830181.txt (asserting a violation of plaintiff-petitioner's First Amendment rights to free speech and association, but failing to "contend that the College's refusal to assure compliance with Title IX [was] based upon any religious tenet" even though the college was affiliated with the Presbyterian Church).

In Hall v. Lee College, Inc., the district court found no violation of Title IX in a college's dismissal of a student and thus did not resolve a question about religious exemption or the procedures by which it might be claimed. 932 F. Supp. 1027, 1033 (E.D. Tenn. 1996). The court in Hall also noted that its research, like mine, revealed no cases construing either the statutory provision for religious exemption itself, 20 U.S.C. § 1681(a)(3) (2012), or the implementing regulations found at 34 C.F.R. $\S 106.12$ (2015). Hall, 932 F. Supp. at 1033. Hall was decided in 1996, more than twenty years after Title IX was first enacted and nearly ten years after it was modified by the Civil Rights Restoration Act of 1987. Civil Rights Restoration Act of 1987, Pub. L. No. 100-259, 102 Stat. 28 (1988); see also Cabading v. Cal. Baptist Univ., No. RIC 1302245 (Super. Ct. Cal., Riverside Cnty. July 11, 2014), http://newscastmedia.com/transgender.pdf (finding that a transgender student's law suit against religious institution did not include a Title IX claim and thus finding no question of religious exemption to it).

4. In the 1970s, a small handful of law review notes briefly mentioned, but did not extensively discuss, religious exemption to Title IX. See, e.g., David B. Frohnmayer, Title IX, Education Amendments of 1972, 2 J.C. \& U.L. 49, 51 (1974); Comment, Implementing Title IX: The HEW Regulations, 124 U. PA. L. REV. 806, 807 (1976); Tim Philpot, Note, Title IX Sex Discrimination Regulations: Impact on Private Education, 65 KY. L.J. 656, 694-699 (1977); David Kroll, Title IX Sex Discrimination Regulations: Private Colleges and Academic Freedom, 13 URB. L. ANN. 107, 133-36 (1977). A few other law review articles in the late 1980s mentioned the existence of religious exemptions to Title IX as the Civil Rights Restoration Act amended it but did nothing more.

5. See, e.g., Jean L. Cohen, Freedom of Religion, Inc.: Whose Sovereignty?, NETH. J. LeGAL PHIL. 2015 (44) 3 (Oct. 19, 2015), http://ssrn.com/abstract=2676141; Frederick Mark Gedicks, 'Substantial' Burdens: How Courts May (and Why They Must) Judge Burdens on Religion under RFRA, 85 GEO. WASH. L. REV. (forthcoming Jan. 2017), http://ssrn.com/abstract=2657733; Philip Hamburger, Equality and Exclusion: Religious Liberty and Political Process (Columbia Pub. Law, Research Paper No. 14-387, 2014), http://ssrn.com/abstract=2404626; Douglas Laycock, Religious Liberty and the Culture Wars, 2014 U. ILL. L. REV. 839 (2014); Ira C. Lupu, Hobby Lobby and the Dubious Enterprise of Religious Exemptions, 38 HARV. J.L. \& GENDER 35 (2015); Martha Minow, Should Religious Groups Be Exempt from Civil Rights Laws?, 48 B.C. L. REV. 781 (2007); Douglas Nejaime \& Reva B. Siegel, Conscience Wars: Complicity-Based Conscience Claims in Religion and Politics, 124 Yale L.J. 2516 (2015); Michael J. Perry, On the Constitutionality and Political Morality of Granting Conscience-Protecting Exemptions Only to Religious Believers (Emory Pub. Law, Research Paper No. 15-356, 2015), http://ssrn.com/abstract=2611158. 
legislative history, university archives, personal interviews, newspaper and web articles, and creation of a database of Title IX religious exemption claims themselves - this study critiques the development of religious exemptions to Title IX from their beginning in 1975 through September 15, 2016, when the Office for Civil Rights updated its website.

Religious exemptions to Title IX pose a particularly urgent question given the flood of new exemptions claims occasioned, in part, by the joint resolution agreement in 2013 among the Department of Education, the Department of Justice, and the Arcadia Unified School District regarding transgender students and the Department of Education's April 2014 "significant guidance document" that expressly included gender identity within Title IX's sex discrimination prohibitions. ${ }^{6}$ Moreover, the Office for Civil Rights' May 13, 2016 Dear Colleague Letter on Transgender Students specifically informs educational institutions that the Department of Education and the Department of Justice interpret Title IX to prohibit discrimination based on gender identity. ${ }^{7}$ In other words, when a student or a student's guardian provides notice that the student will assert a gender identity different from "previous representations or records," the school must begin treating the student "consistent with the student's gender identity.",

Experience with religious exemptions to Title IX is further relevant to current debates regarding institutional religious exemptions in other areas of the law. For example, in September 2015, the Department of

6. U.S. DeP'T OF EduC. \& U.S. Dep'T OF Justice, Resolution AgREEMENT BetweEn the Arcadia Unified School District, the U.S. Department of Education, OfFice for Civil Rights, and the U.S. Department of Justice, Civil Rights Division (2013) [hereinafter ARCADIA RESOLUTION AGREEMENT], http://www.justice.gov/sites/default/files/crt/legacy/2013/07/26/arcadiaagree.pdf; U.S. DEP'T OF EDUC., QUestions AND ANSWERS ON Title IX AND SEXUAL Violence (2014), http://www2.ed.gov/about/offices/list/ocr/docs/qa-201404-title-ix.pdf.

I anticipated that the Supreme Court's recognition of a constitutional right to same-sex marriage in Obergefell v. Hodges, 135 S. Ct. 2584 (2015), would also motivate certain religious educational institutions to claim exemption, but only one of the forty-nine exemption claims made after Obergefell was decided on June 26, 2015, had done so by September 15, 2016, the end date for my data. See Letter from Reverend Charles Bartlett, President, World Baptist Fellowship (Arlington Baptist Coll.), to Assistant Sec'y, Office for Civil Rights, U.S. Dep't of Educ. (Dec. 22, 2015), www2.ed.gov/about/offices/list/ocr/docs/t9-rel-exempt/arlington-baptist-college-request-

12222015.pdf (citing Obergefell decision as justification for requesting an exemption). In the citations that follow, I sometimes abbreviate the Office for Civil Rights as OCR and the Department of Education as DOE.

7. Catherine E. Lhamon \& Vanita Gupta, Dear Colleague Letter on Transgender Students, U.S. DEP'T EDUC. 1-3 (May 13, 2016), http://www2.ed.gov/about/offices/list/ocr/letters/colleague201605-title-ix-transgender.pdf.

8. Id. at 2 . 
Health and Human Services asked for comments on whether its regulatory procedures for implementing exemptions to the Affordable Care Act should track those of Title IX found in 34 C.F.R. $\S 106.12 .{ }^{9}$ More generally, religious exemptions to Title IX may interact with proposed non-discrimination legislation like the federal Equality Act in unexpected or at least non-obvious ways. ${ }^{10}$

Parts II and III explicate the statutory provision for religious exemptions to Title IX and its associated regulatory procedures as well as the surrounding controversy and resistance that accompanied their creation and initial implementation. Part IV reveals the policies and practices - unpublished until mid-2016 and then only partially made public - by which the Department of Education's Office for Civil Rights (OCR) has considered religious exemption claims for the past forty years. The Office for Civil Rights' application of those policies in hundreds of factual instances has resulted in 285 exemptions recognized and 0 denied. ${ }^{11}$ Throughout Part IV, my analysis and factual conclusions rely on a Title IX Religious Exemption Database that I created and coded from institutions' exemption claims and OCR's responses. ${ }^{12}$

On its face, a score of 285 and counting suggests complete and overwhelming victory for one side: the educational institutions claiming religious exemption to Title IX. In more than forty years, the federal government has never denied a religious exemption claim to Title IX, not once. In reality, however, the lopsided score hides another story, one much more complex and nuanced than the score reflects. Part V analyzes how, over time, the government agency charged with Title IX enforcement - the Office for Civil Rights, first at the Department of Health, Education and Welfare and then, after 1980, at the Department of

9. See Nondiscrimination in Health Programs and Activities, 80 Fed. Reg. 54172 (proposed Sept. 8, 2015) (to be codified at 45 C.F.R. pt. 92).

10. For example, LAMBDA LEGAL notes that "The [2015] Equality Act updates the law to add explicit protections for sex, sexual orientation, and gender identity to existing civil rights laws. It does not change the religious exemptions already in place in federal law." Equality Act: Frequently Asked Questions, LAMBDA LEGAL, http://www.lambdalegal.org/sites/default/files/publications/downloads/equality_act_faq_coalition_fi nal_7.22.pdf (last visited Oct. 7, 2016). LAMBDA LEGAL recognizes the potential interaction between the Equality Act and Title VII's provisions regarding employment as well as the Fair Housing Act but says nothing about religious exemptions to Title IX. Id.

11. See supra note 1.

12. I obtained the majority of the claim letters and OCR responses through repeated FOIA requests in 2015. Most, but not all, of the documents that I received through FOIA requests are now published on OCR's website. I coded the data to allow identification of patterns in both the claim letters and OCR responses. To support factual conclusions I make throughout this article based on the primary source research the database contains, I cite the database as Title IX Religious Exemption Database (Sept. 15, 2016) (developed by and on file with author). 
Education - subtly but surely arrogated to itself power and authority to regulate religious exemption to Title IX, just as opponents of the regulatory procedure initially predicted. Like Part IV, analysis and conclusions in Part V rely heavily on my Title IX Religious Exemption Database. As much as victory, the score reveals a subtle erosion of autonomy as religious educational institutions acquiesce to the administrative state by requesting exemption under regulatory procedures rather than claiming their inherent exemption under the Title IX statute itself and the Constitution. Moreover, the historic lack of publicity and transparency regarding religious exemption to Title IX facilitated OCR's arrogation of power while concomitantly impeding both efficiency and fairness as it undermined the non-discrimination principles of Title IX itself.

Part VI concludes that the administrative regulatory procedures for religious exemption to Title IX have largely failed to accomplish the non-discrimination goals of Title IX, to respect religious liberties, or to facilitate a sustainable engagement between these potentially competing values. Even with resolution of the transparency and publicity problems that have plagued religious exemption to Title IX, Title IX should not be a model for other areas of potential conflict between religion and nondiscrimination. Religious exemption to otherwise generally applicable law should be public and publicized, but publicity alone is not sufficient to address Title IX's challenges. In a pluralistic society, more important are the basic questions of who makes individual determinations of institutional religious exemption and by what criteria. More than forty years after the implementation of Title IX, there are few clear answers to either question. One thing, however, is clear: the Office for Civil Rights has never said "no" to a claim of religious exemption to Title IX.

\section{STATUTORY PROVISIONS}

As a generally applicable federal civil rights law, Title IX of the Education Amendments of 1972, known colloquially simply as "Title IX," prohibits sex discrimination in education programs and activities that receive federal funds. ${ }^{13}$ Title IX is most famous for increasing the sports and athletic opportunities available to girls and young women during their formative educational years, although it has more recently become a tool for addressing sexual assault on campus. While the statutory language of Title IX is relatively general, the implementing

13. 20 U.S.C. $\S \S 1681-1688(2012)$. 
regulations more specifically prohibit discrimination based on sex in admissions, hiring, employment and student recruiting, housing, facilities, access to classes and schools, counseling and use of appraisal and counseling materials, financial assistance, employment assistance to students, health and insurance benefits and services, marital or parental status, athletics, textbooks and curricular material, and more. ${ }^{14}$

Title IX provides that any public or private elementary or secondary school, school district, college, or university that receives any federal funding, including indirectly through financial aid to students, must comply with Title IX's non-discrimination requirements. ${ }^{15}$ Within those parameters, however, Title IX exempts from compliance educational institutions controlled by a religious organization with contrary religious tenets. ${ }^{16}$ By its express terms, Title IX allows an educational institution to discriminate based on sex if two criteria are met: 1) it is "controlled by a religious organization," and 2) application of Title IX "would not be consistent with the religious tenets" of that organization. ${ }^{17}$

\section{REGULATORY IMPLEMENTATION}

\section{A. Draft Regulations}

The federal Department of Health, Education, and Welfare (HEW) first proposed draft regulations to Title IX in June 1974, two years after the law's passage. ${ }^{18}$ In contrast to the statute, the draft regulations included a procedural mechanism by which educational institutions could claim a religious exemption. ${ }^{19}$ The draft regulations assigned to the Director of the Office for Civil Rights at HEW, the authority to determine eligibility for a religious exemption:

An education institution which wishes to claim the exemption ... shall do so in writing to the Director when filing the assurance required by $\S$ [106].4, setting forth the extent of the requested exemption and enclosing a statement of the religious tenets under which the exemption

14. 34 C.F.R. $\S \S 106.21-106.61(2015)$.

15. 20 U.S.C. $\$ 1681(2012)$.

16. 20 U.S.C. $\$ 1687$.

17. 20 U.S.C. $\S 1681(\mathrm{a})(3)$; see also 20 U.S.C. $§ 1687$ (defining covered "program or activity" except that "such term does not include any operation of an entity which is controlled by a religious organization if the application of section 1681 of this title to such operation would not be consistent with the religious tenets of such organization").

18. Education Programs and Activities Receiving or Benefiting from Federal Financial Assistance, 39 Fed. Reg. 22228 (proposed June 20, 1974) (codified at 45 C.F.R. pt. 86).

19. Id. at 22234 . 
is claimed and any other information which might aid the Director in determining whether the institution qualifies for such exemption. ${ }^{20}$

During the 120-day notice and comment period, nearly 10,000 individuals and institutions formally responded to the proposed regulations. $^{21}$

\section{B. Final Regulations, Congressional Review, and Related Opposition}

HEW made substantive changes in the religious exemption procedure when it promulgated final regulations for Title IX in June 1975 by "modif[ying] and simplif[ying]" the language. ${ }^{22}$ The final version of what is now 34 C.F.R. § 106.12(b), the procedural mechanism for claiming a religious exemption, removed the draft language quoted above that allowed the Director of the Office for Civil Rights at HEW to decide whether an educational institution qualified for the religious exemption, as well as the requirement that educational institutions claim a religious exemption at the same time as filing the assurance of compliance required by $\S 106.4 .^{23}$ The final version of what is now $\S$ 106.12(b) read "[a]n educational institution which wishes to claim the exemption ... shall do so by submitting in writing to the Director a statement by the highest ranking official of the institution, identifying the provisions of this part which conflict with a specific tenet of the religious organization." 24 The final version made the statement of religious exemption itself sufficient, without review or qualification by a government agency.

20. Id.; see also 45 C.F.R. $\S 86.12$ (b) (2015). The regulations were initially numbered as 45 C.F.R. pt. 86, but are now codified at 34 C.F.R. pt. 106 . Establishment of Title and Chapters, 45 Fed. Reg. 30802 (May 9, 1980) (codified at 34 C.F.R. chs. I-VIII). For continuity's sake and ease of reference, the text of this article uses the current C.F.R. citation of 34 C.F.R. pt. 106.

21. See, e.g., Sex Discrimination Rules, in 31 CONG. Quarterly Almanac 1975, at 661, 662 (1976) [hereinafter Sex Discrimination Rules], http://library.cqpress.com/cqalmanac/cqal751211850 .

22. Department of Health, Education, and Welfare, General Administration, 40 Fed. Reg. 24128, 24130 (June 4, 1975) (codified at 45 C.F.R. pt. 86).

23. Compare Education Programs and Activities Receiving or Benefiting from Federal Financial Assistance, 39 Fed. Reg. at 22234, with 45 C.F.R. $\S 86.12$ (1975), and 45 C.F.R. $\S 86.4$. As noted above, the regulations were initially numbered as 45 C.F.R. pt. 86, but are now codified at 34 C.F.R. pt. 106. Establishment of Title and Chapters, 45 Fed. Reg. 30802 (May 9, 1980) (codified at 34 C.F.R. chs. I-VIII).

24. 45 C.F.R. § 86.12(b) (1975); see also Department of Health, Education, and Welfare, General Administration, 40 Fed. Reg. at 24139. 
Even though these Title IX regulations were termed final, they were still subject to a forty-five-day congressional review period. ${ }^{25}$ If, during the review period, Congress found the regulations, or any portion of them, to be "inconsistent" with the statutory authority of Title IX, it could "disapprove" of the final regulations and require HEW to redraft the offending provisions. ${ }^{26}$ If Congress chose not to act, the final regulations would automatically become effective at the end of the fortyfive-day period. ${ }^{27}$

During congressional hearings held during the review period, two associations voiced significant concerns regarding the procedures for obtaining a religious exemption under $\S$ 106.12(b): the American Association of Presidents of Independent Colleges and Universities (AAPICU) and the United States Catholic Conference. ${ }^{28}$ Dallin Oaks testified as director and secretary of the AAPICU and also as president of Brigham Young University, a university sponsored by the Church of Jesus Christ of Latter-day Saints (LDS) and in 1975 the largest private university in the United States as measured by fulltime enrollment. ${ }^{29}$ In President Oaks' view, the procedure set forth in the final version of $\S$ 106.12(b) was "demeaning and inconsistent with the Federal Constitution" as it required educational institutions to "go hat-in-hand to a Government administrator, to demonstrate what religious tenet support[ed] the particular point of view" on which the institution based its religious exemption claim. ${ }^{30}$ The procedure was "an interference with religious belief and practice," particularly because the United States Supreme Court had held in various cases that "it is not part of the business of Government to get into the business of religious belief or practice." ${ }^{31}$ In fact, President Oaks argued that, by means of $\S 106.12(\mathrm{~b})$, "Government and not the church becomes the final arbiter of religious worship, practice, and belief," an entanglement the First Amendment

25. Under $\S 431(\mathrm{~d})$ of the General Education Provisions Act, as amended by the Education Amendments of $1974 \S 509$ (a)(2), Congress had forty-five days in which to review the regulations. Monte N. Stewart, HEW's Regulation Under Title IX of the Education Amendments of 1972: Ultra Vires Challenges, 1976 BYU L. REV. 133, 146; see also Sex Discrimination Rules, supra note 21, at 663.

26. 20 U.S.C.A. $§ 1232(d)$ (Supp. 1976), repealed by Education Amendments of 1984, Pub. L. No. 98-511, 98 Stat. 2366 (1984).

27. $I d$.

28. Sex Discrimination Regulations: Hearings Before the Subcomm. on Postsecondary Educ. of the H. Comm. on Educ. and Labor, 94th Cong. 228-66, 588-91 (1975).

29. Id. at 228, 262 (statement of Dallin H. Oaks, President, Brigham Young University, and Director and Secretary, Association of Presidents of Independent Colleges and Universities).

30. Id. at 258 .

31. Id. 
forbade. $^{32}$ The AAPICU contended further that $\S 106.12(\mathrm{~b})$ constituted "an outrageous and flagrant violation of academic and religious freedom." 33 Resolution of this constitutional violation was quite simple: delete subsection (b). ${ }^{34}$ Through President Oaks, the AAPICU first suggested, then demanded, withdrawal of $\S 106.12(b) .{ }^{35}$ The AAPICU voiced no objection to $\S 106.12$ (a), the substantive portion of the regulatory religious exemption, because it merely tracked the language of the statute to substantiate the religious exemption, but objected only to the procedural requirement of $\S 106.12(\mathrm{~b}) .{ }^{36}$ In President Oaks' argument, eliminating the procedural requirement would "be a restatement of the statutory intent of Congress" and allow claims of discrimination and religious exemption under Title IX to be heard in court rather than resolved by an executive agency. ${ }^{37}$ President Oaks maintained that the federal judiciary, not the executive branch, was the government entity "traditionally embued [sic]" with the responsibility of determining violations of regulations and statutes and thus the appropriate entity to do so under Title IX, if government had to be involved at all. ${ }^{38}$ President Oaks and the AAPICU resisted the expansion of the administrative state and sought to maintain the distinctive educational experiences that they perceived independent and religious secondary institutions provided.

Like President Oaks and the AAPICU, the United States Catholic Conference deemed the substantive religious exemption in $\S 106.12$ (a) appropriate, but opposed the procedures outlined in 34 C.F.R. $\S$ 106.12(b), particularly in its draft form as it expressly allowed an executive agency to determine an educational institution's qualification for the religious exemption. ${ }^{39}$ To support its argument, the U.S. Catholic Conference cited Supreme Court decisions in Walz v. Commissioner-as had President Oaks - and Lemon v. Kurtzman, for what it termed the First Amendment's categorical mandate of church/state neutrality. ${ }^{40}$

\footnotetext{
32. Id. at 231 .

33. Id. at 248 (statement of David Andrews, President, American Association of Presidents of Independent Colleges and Universities).

34. Id. at 263 (statement of Gordon C. Coffman, Att'y, Wilkinson, Cragun \& Barker, legal counsel to President Oaks and Brigham Young University).

35. Id.

36. Id.

37. Id.

38. Id.

39. Id. at 588-89 (statement of Eugene Krasicky, Office of General Counsel, United States Catholic Conference).

40. Id. at 589 (first citing Walz v. Tax Comm'n of N.Y., 397 U.S. 664 (1970); then citing
} 
Church/state neutrality required that the state "refrain from a surveillance of religion or religious activities," a requirement that $\S 106.12$ (b) "totally ignored." 41 Unlike President Oaks and the AAPICU, however, the U.S. Catholic Conference offered a solution other than complete elimination of $\S 106.12(b){ }^{42}$ Rather than having educational institutions submit a written statement of religious tenets that the government would then evaluate to determine eligibility for exemption, the U.S. Catholic Conference proposed a self-certification procedure. ${ }^{43}$ The certification would simply be a statement of fact, a statement of the educational institution's status as a religiously exempt institution. ${ }^{44}$ Self-certification would "avoid serious constitutional issues and at the same time provide a workable administrative procedure." $" 45$

The final version of $\S 106.12$ (b) approximated the self-certification proposal of the U.S. Catholic Conference as it removed the language of the draft regulation that allowed the government agency to "determin[e] whether the institution qualifies" for the religious exemption. ${ }^{46}$ Unlike President Oaks and the AAPICU, the U.S. Catholic Conference recognized the need for some administrative procedure, as long as the government did not surveil religious institutions or determine the credibility of claims to a religious exemption.

During the forty-five-day review period, the House of Representatives' Postsecondary Education Subcommittee voted by voice to disapprove the religious exemption procedures as part of a larger disapproval resolution that would have required HEW to rewrite the regulations. ${ }^{47}$ The House Education and Labor Equal Opportunities Subcommittee, to which the subcommittee's disapproval resolution had been referred, unanimously recommended that the full committee reject the disapproval resolution, which it did, despite the opposition of the AAPICU, the U.S. Catholic Conference, and a congressman's complaint

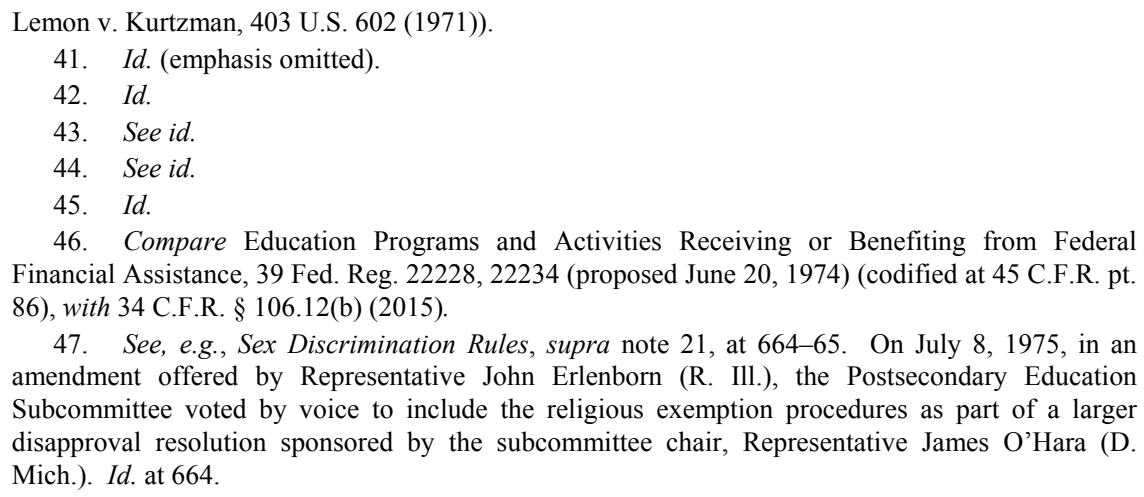

47. See, e.g., Sex Discrimination Rules, supra note 21, at 664-65. On July 8, 1975, in an amendment offered by Representative John Erlenborn (R. Ill.), the Postsecondary Education Subcommittee voted by voice to include the religious exemption procedures as part of a larger disapproval resolution sponsored by the subcommittee chair, Representative James O'Hara (D. Mich.). Id. at 664. 
that HEW had "add[ed] exceptions and exemptions and explications and explanations until what the public is told to do by the regulation bears only a general resemblance to what the law tells them to do."48 Congress did not require HEW to redraft the final regulations. ${ }^{49}$ At the end of the review period on July 21, 1975, the final regulations became effective with the procedural requirement of $\S 106.12$ (b) intact. $^{50}$ Educational institutions controlled by religious organizations that claim exemption to Title IX "shall do so by submitting in writing to the Director a statement by the highest ranking official of the institution, identifying the provisions of this part which conflict with a specific tenet of the religious organization." $" 51$

\section{DeVEloping RELIGIOUS EXEMPTION PoliCy AND PRACTICE}

\section{A. Inherent Exemption-Ad Hoc Resolution of Three Religious Exemption Claims, 1976}

\section{Brigham Young University}

Following on his testimony before Congress against the regulation's religious exemption procedure and their subsequent enactment, President Dallin Oaks led Brigham Young University to receive in August 1976 the first formal acknowledgement from HEW's Office for Civil Rights (OCR) of a religious exemption to Title IX. The process by which OCR and BYU arrived at the exemption was rocky with the University continuing to assert the constitutional invalidity of the religious exemption procedure.

On October 31, 1975, about four months after his congressional testimony, President Oaks wrote to David Mathews, Secretary of Health, Education, and Welfare. ${ }^{52}$ Rather than requesting an exemption and

48. Id. at 665. Representative O'Hara complained that HEW "add[ed] exceptions and exemptions and explications and explanations until what the public is told to do by the regulation bears only a general resemblance to what the law tells them to do." Id.

49. Id.

50. $I d$.

51. 45 C.F.R. $\S 86.12$ (b) (1975). As noted above, the regulations were initially numbered as 45 C.F.R. pt. 86, but are now codified at 34 C.F.R. pt. 106. Establishment of Title and Chapters, 45 Fed. Reg. 30802 (May 9, 1980) (codified at 34 C.F.R. chs. I-VIII). The submission is now made to the OCR at the Department of Education, a successor agency to HEW. See 34 C.F.R. § 106.12(b) (2015); see also Department of Education Organization Act, Pub. L. No. 96-88, 93 Stat. 668 (1979) (codified at 20 U.S.C. $\S \S 3401-3510$ (2012)).

52. Letter from Dallin H. Oaks, President, Brigham Young Univ., to David Mathews, Sec'y, Dep't of Health, Educ., \& Welfare (Oct. 31, 1975) (on file at Margaret Dunkle Papers, MC 530, 
thereby implicitly recognizing the administrative agency's authority to decide religious exemption claims under Title IX, President Oaks boldly asserted BYU's exempt status as inherent and already existent. He notified HEW of BYU's exemption, rather than either claiming or requesting an exemption. ${ }^{53}$ Oaks' letter was to "serve as official notification that Brigham Young University and Brigham Young University-Hawaii Campus consider themselves exempt from portions of the provisions" of the Title IX regulations "because such sections conflict with the religious teachings of the Church of Jesus Christ of Latter-Day Saints, which sponsors these institutions." 54 President Oaks' letter alleged specific conflict between LDS teachings and the regulations' requirement of non-discrimination regarding marital/parental status in admissions, marital/parental status in the education program, pregnancy in employment, and appearance. ${ }^{55}$

Beyond notifying HEW that BYU was inherently exempt, President Oaks made clear that the statement gave no ground whatsoever:

We do not concede that the Department of Health, Education and Welfare has the power to review our claim of exemption on the ground of religion. Our rights to the free exercise of religion are granted and fully protected by the United States Constitution, which prohibits any government inquiry into the truth of our religious principles or the sincerity of our belief in them. Title IX also exempts religious institutions. $^{56}$

President Oaks maintained that the regulation's religious exemption procedure was both unconstitutional and ultra vires of the statute. ${ }^{57}$ Even so, BYU did "not wish to be seen as defying the authority given to the Department of Health, Education and Welfare under Title IX or other civil rights statutes" as BYU "fully support[s] the goal of equal opportunity for all persons." 58 If HEW were to engage in a review of BYU's notice letter, the sort of review that President Oaks had just described as unconstitutional and ultra vires, Oaks was "certain" that HEW would "see that Brigham Young University does not discriminate unlawfully against members of either sex and that a reasonable

\footnotetext{
folders 11.3-11.7, Item Nos. 11.7367-11.7371, Schlesinger Library, Radcliffe Institute, Harvard University).

53. Id. at 1 .

54. Id.

55. Id.

56. Id. at 2

57. Id.

58. Id. at 3 .
} 
interpretation of Title IX and the regulations would find [BYU] in compliance." 59

President Oaks attached to his letter a copy of a document titled "Notification of Brigham Young University Policy of NonDiscrimination on the Basis of Sex" which BYU had published as a paid advertisement in the university newspaper and two other newspapers in the previous weeks. ${ }^{60} 34$ C.F.R. $§ 106.9$ required initial public dissemination of each university's Title IX policy within ninety days of the regulations' effectiveness, mandating publication in local newspapers and alumni magazines, and most specifically written communication that would be "distributed to every student and employee" of the educational institution. ${ }^{61}$ The published notification developed arguments and provided additional detail that fleshed out the position President Oaks articulated in his cover letter to HEW.

First, as in President Oaks' letter, the notification expressed BYU's commitment to "equal opportunity for men and women in education and employment," arguing that BYU was "already in compliance" with many provisions of Title IX having rectified "[a]ny past policy or practice of the University which may have implied discrimination on the basis of sex." ${ }^{~} 2$ BYU's policy forbidding sex discrimination provided:

The Board of Trustees of Brigham Young University endorses the goal of equal opportunity for men and women in education and employment. Brigham Young University does not discriminate on the basis of sex among its students or employees, or among applicants for admission or employment. We support the nondiscrimination laws and have modified various University policies or procedures which in the past may have been interpreted as discrimination on the basis of sex. ${ }^{63}$

Without admitting actual discrimination, twice the notification acknowledged that BYU's past practices may have implied or been

\footnotetext{
59. Id.

60. See Press Release, Brigham Young Univ., Notification of Brigham Young University Policy of Non-Discrimination on the Basis of Sex (Oct. 16, 1975) [hereinafter BYU Notification] (on file at Margaret Dunkle Papers, MC 530, folders 11.3-11.7, Item Nos. 11.7367-11.7371, Schlesinger Library, Radcliffe Institute, Harvard University); Notification of Brigham Young University Policy of Non-Discrimination on the Basis of Sex, DAILY UNIVERSE (Provo, Utah), Oct. 21, 1975; Notification of Brigham Young University Policy of Non-Discrimination on the Basis of Sex, DeSERET News (Salt Lake City, Utah), Oct. 18, 1975, at 10A; Notification of Brigham Young University Policy of Non-Discrimination on the Basis of Sex, DAILY HeRALD (Provo, Utah), Oct. 19, 1975 , at 44.

61. 34 C.F.R. $\S 106.9(2015)$.

62. See BYU Notification, supra note 60 .

63. Id.
} 
interpreted as discrimination based on sex. ${ }^{64}$

The notification detailed the positive actions that the University had taken to "insure [sic] equal opportunities for men and women": 1) awarding university scholarships without discrimination, 2) increasing funding for women's athletics programs and access to facilities and opportunities, 3) eliminating more restrictive housing regulations for women, 4) regularly reviewing salaries for female faculty and staff for equal pay for equal work, 5) identifying and resolving inequalities in hiring and promotion, 6) encouraging the avoidance of sex stereotyping in "textbooks, curriculum, and student advertisements," and 7) "urging women students to pursue their educational interests with seriousness and vigor." 65

While BYU stated that it shared the goal of equal opportunity for men and women, it nonetheless disputed "the legality and constitutionality of certain Title IX regulations" as an invasion of religious freedom. ${ }^{66}$ The notification urged observers to view BYU's opposition to the regulations as principled and "authorized by the Constitution and laws of the United States," rather than belligerent "defiance of the law." 67 Even though BYU resisted the administrative state, it would submit itself to judicial process, were it to arise, and "comply with any regulation ultimately sustained as lawful by the courts of the United States" as part of the law-abiding religious community its scripture and doctrine encouraged. ${ }^{68}$ In the absence of a judicial ruling on the validity of the regulations, however, the University would follow its own interpretation, an interpretation that represented the University's "best judgment on the meaning of the constitution [sic] and laws that govern us" and allowed the University to declare its exemption. ${ }^{69}$

In the last paragraph of the notification, the University moved away from legal arguments. The University explained that it had grounded its refusal to comply with certain regulations in legal principles, but it also objected to Title IX regulations on moral grounds. ${ }^{70}$ The notification proclaimed that:

\footnotetext{
64. See id.

65. Id.

66. Id.

67. Id.

68. Id. ("Our Church teaches the necessity of 'obeying, honoring and sustaining the law' (Articles of Faith 12) and of 'befriending that law which is the constitutional law of the land' (Doc[trine] and Cov[enants] 98:6).").

69. See id.

70. Id.
} 
The teaching of honesty, integrity and chastity must not become exclusively the province of religion. If our government not only abandons the advocacy of moral standards but positively prohibits the practice of such values at teaching institutions, as these regulations appear to do, the destruction of America as a great nation will be both imminent and inevitable. ${ }^{71}$

Beyond its stated objection to regulations involving sex and dress codes - the chastity portion of the moral standards - the notification did not explain how the Title IX regulations limited honesty and integrity at educational institutions or impeded them from teaching those values. ${ }^{72}$ The link between the regulations and the "imminent and inevitable" destruction of America was likewise assumed rather than explained. ${ }^{73}$

Public statements by the University to the press aggressively supported the boldness of President Oaks' letter and the published notification, coming close to the defiance those documents eschewed. The Chronicle of Higher Education quoted one unnamed university spokesman saying, "We don't mind stating our position, ... but we won't allow a bureaucrat in Washington to decide if we are sincere." Without judicial resolution of the regulations' constitutionality, a BYU spokesman said the University would "simply ignore" the regulations while hoping HEW, the administrative agency, ignored it. ${ }^{75}$ The Chronicle of Higher Education's report reiterated the regulations the University resisted, the same ones spelled out in President Oaks' letter to HEW. ${ }^{76}$ The University would not comply with regulations prohibiting "inquiries and actions concerning the parental or marital status of present or prospective students and employees, or their pregnancy or termination of pregnancy" or admit unwed mothers or women who had abortions "because [BYU] condemns promiscuity."77 Similarly, The Chronicle of Higher Education reported that BYU would maintain its differential dress codes for men and women because, BYU believed that "differences in dress and grooming of men and women are proper expressions of God-given differences in the sexes." ${ }^{, 78}$ The Board of Trustees had

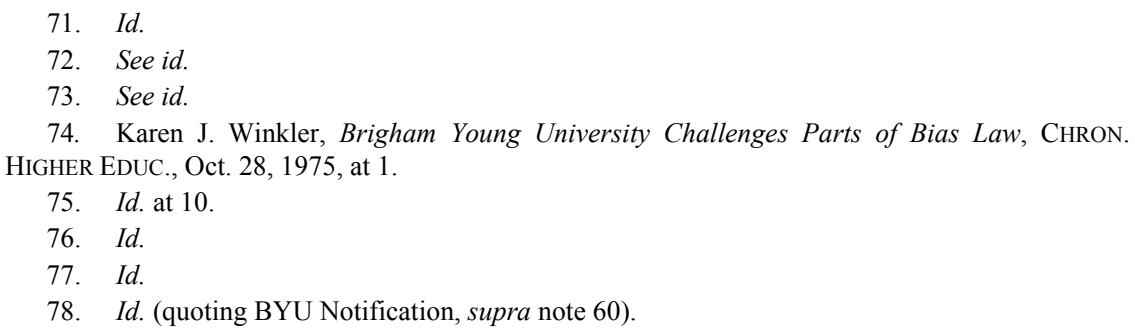


allowed women students at BYU to wear pants and slacks to class in 1971, but not to wear jeans. ${ }^{79}$ Male students could wear pants including jeans but not have long hair or beards. ${ }^{80}$

HEW did not ignore BYU, but Oaks' boldness paid off. Five months later in March 1976, Martin Gerry, the Acting Director for the Office for Civil Rights, responded to President Oaks, essentially acceding to Oaks' interpretation of the regulations that 1) religious educational institutions were inherently exempt and 2) the agency's power of review was minimal to non-existent. ${ }^{81}$ The Acting Director reiterated the regulatory language of $\S 106.12$ (a) that tracked Title IX itself, but made no specific mention of the procedure created in $\S 106.12(\mathrm{~b})$, stating instead that OCR understood its responsibilities under the whole of $\S 106.12$ "as principally assuring that the institutions claiming exemptions have a full understanding of the provisions from which they believe themselves exempt." ${ }^{\text {" }}$ More specifically, OCR had "no intention of reviewing the nature of the religious tenets asserted by a university to be in conflict with the Title IX regulations, as a general matter." ${ }^{, 3}$ Thus, improving educational institutions' understanding of Title IX, not reviewing their claims, was OCR's stated authority over religious exemption claims.

The Acting Director suggested tentatively, almost hopefully, that, perhaps no actual conflict existed between the substance of Title IX regulations and BYU's Honor Code as it reflected LDS religious tenets. ${ }^{84}$ OCR interpreted the regulatory sections regarding pregnancy, marital status, and appearance Oaks had identified in his letter to "not preclude institutions from imposing standards of morality (so long as those standards apply equally to members of both sexes)." 85 Rather, OCR asked BYU for more information, that it "identify more specifically the provisions of the sections you have cited which you feel conflict with particular practices of Brigham Young University which, in turn, are

79. Id.; see also Dallin H. Oaks, Standards of Dress and Grooming, NEW ERA, Dec. 1971, at 46, 47, https://www.lds.org/new-era/1971/12/standards-of-dress-and-grooming. I vividly remember walking into Mrs. Lucas' first grade class at Sandpoint Elementary School rocking my homemade pink polyester pantsuit when my mother let me wear pants to school for the first time because BYU had changed its rule to allow women to wear pants to class.

80. Winkler, supra note 74 , at 10.

81. Letter from Martin H. Gerry, Acting Dir., Office for Civil Rights, Dep't of Health, Educ., \& Welfare, to Dallin H. Oaks, President, Brigham Young Univ. (Mar. 17, 1976) [hereinafter Gerry Letter dated Mar. 17, 1976] (on file at Margaret Dunkle Papers, MC 530, folders 11.3-11.7, Item Nos. 11.7352-11.7353, Schlesinger Library, Radcliffe Institute, Harvard University).

82. Id. at 1 .

83. Id.

84. Id.

85. Id. 
derived from the religious tenets of the Church of Jesus Christ of LatterDay Saints."

President Oaks returned Acting Director Gerry's softball with another letter as firm and resolute as the first. ${ }^{87}$ BYU reiterated its belief that "the Constitution forbids any government involvement in the teaching or practice of religion," maintaining that the University provided information to OCR "in a spirit of goodwill" and of its own choice without waiving "any right to the protection of the Constitution in such matters in this or any future inquiry." ${ }^{88}$ Even though it was not legally bound to do so, the University supported "the goal of nondiscrimination" and "voluntarily decided to follow the regulations that are not in conflict with our constitutional rights" in all areas of the University, not just the limited few that received federal funding. ${ }^{89}$ Despite the truculent tone of the letter, Oaks proffered BYU's humility; it did not "desire or intend to provoke a confrontation with any arm of government," but only to "preserv[e] [its] vital constitutional rights and limit[] the exercise of regulatory authority over [its] private churchrelated university to what is clearly and validly authorized by law." $" 90$

In voluntarily offering information, President Oaks described the LDS Church's religious tenets that prohibited extra-marital sex and abortion. ${ }^{91}$ Here, he stated the LDS Church's moral standards were "the same for both sexes" and the University's Honor Code applied "equally to members of both sexes." 92 LDS theology nonetheless differentiated between men and women: "The Church also teaches that while men and women are equal in the sight of God, He has assigned separate roles to each and these roles should not be confused." 93 This gender role

86. Id.

87. Letter from Dallin H. Oaks, President, Brigham Young Univ., to Martin H. Gerry, Acting Dir., Office for Civil Rights, Dep't of Health, Educ., \& Welfare (Apr. 10, 1976) (on file at Margaret Dunkle Papers, MC 530, folders 11.3-11.7, Item Nos. 11.7354-11.7356, Schlesinger Library, Radcliffe Institute, Harvard University).

88. Id. at 1 .

89. Id. BYU argued that it was not bound to follow Title IX regulations in areas of the University that did not receive direct federal funding, a position upheld by the United States Supreme Court in Grove City College v. Bell, 465 U.S. 555 (1984), but overturned in the Civil Rights Restoration Act of 1987, Pub. L. No. 100-259, 102 Stat. 28 (1988).

90. Letter from Dallin H. Oaks, President, Brigham Young Univ., to Martin H. Gerry, Acting Dir., Office for Civil Rights, Dep't of Health, Educ., \& Welfare 3 (Apr. 10, 1976) (on file at Margaret Dunkle Papers, MC 530, folders 11.3-11.7, Item Nos. 11.7354-11.7356, Schlesinger Library, Radcliffe Institute, Harvard University).

91. Id. at 2 .

92. Id.

93. Id. 
differentiation was used to justify differences in BYU's required Dress and Grooming Standards for men and women. ${ }^{94}$

With respect to a conflict between the LDS Church's religious tenets and the Title IX regulations, President Oaks took issue with Acting Director Gerry's statement that the regulations did "not preclude institutions from imposing standards of morality (so long as those standards apply equally to members of both sexes)." ${ }^{95}$ Rather, in Oaks" view, the regulations forbade BYU from "dismissing or refusing to admit or hire students or employees who violate [LDS] standards" with respect to abortion and extra-marital pregnancy or childbirth. ${ }^{96}$ BYU read the regulations to mean that it could not "take action against a woman who is pregnant out of wedlock or has obtained an abortion," but it could take action against that woman's male partner, calling "preposterous" and "unconstitutional" this "differential regulatory protection of men and women... in regulations purporting to abolish sex discrimination." 97 Although he cited "the plain language of the Title IX regulations" to support his reading of the regulations, President Oaks asked OCR to "please advise" the University if its "interpretation is in error, so that the Title IX regulations do permit [BYU] to apply its moral standards equally to men and women." "98 The University wanted to accept OCR's "assurance that [BYU's] practices under [LDS] moral standards do not conflict with the regulations so long as enforcement is uniform for men and women," but was leery in doing so. ${ }^{99}$ After HEW officials visited the Brigham Young University campus in April, OCR "granted" BYU's claimed exemptions, documenting its basic acquiescence to BYU's position in an August 1976 letter. $^{100}$

\footnotetext{
94. Id.

95. Id. (quoting Gerry Letter dated Mar. 17, 1976, supra note 81, at 1).

96. Id.

97. Id. at $2-3$.

98. Id.

99. Id. at 3 .

100. Letter from Martin H. Gerry, Acting Dir., Office for Civil Rights, Dep't of Health, Educ., \& Welfare, to Dallin H. Oaks, President, Brigham Young Univ. (Aug. 12, 1976) (on file at Harold B. Lee Library, L. Tom Perry Special Collections, UA 1085, Box 254, Folder 2). OCR's webpage for religious exemptions to Title IX does not include BYU's 1975 exemption claim nor OCR's recognition of it in Gerry's 1976 letter to President Dallin Oaks. See Office for Civil Rights, Religious Exemptions Index Prior to 2009, U.S. DEP'T EDUC. (June 13, 2016), http://www2.ed.gov/about/offices/list/ocr/docs/t9-rel-exempt/z-index-links-list-pre-2009.html. Likewise, despite my numerous FOIA requests and telephone conversations with OCR, OCR was unable to find a copy of the 1976 communication with BYU in its religious exemption files.
} 


\section{St. Charles Borromeo Seminary}

St. Charles Borromeo Seminary's pursuit of religious exemption in August 1976 and HEW's response the next month were both starkly brief in contrast with the extended argument between HEW and BYU that lasted over thirteen months. In a single paragraph, the Rev. Msgr. Vincent L. Burns stated that St. Charles Borromeo was "a Roman Catholic seminary controlled by the Archdiocese of Philadelphia" that existed to train "men for the Catholic priesthood." 101 As such, admitting non-Catholic students or women would conflict with its religious tenets. ${ }^{102}$ After quoting the religious exemption language of Title IX and the seminary's description of itself, HEW stated simply, "the admission practices of your institution are exempt from Title IX coverage ( $\S$ [106].21 [sic])." $" 103$

Rhetorically, St. Charles Borromeo presented facts. It made no notification, no claim, no request. HEW responded in kind; the seminary was exempt.

\section{Harding College}

Harding College's interaction with HEW fell between the extremes of BYU's lengthy negotiations and St. Charles Borromeo's brief declaration. On July 21, 1976, Harding College President Clifton Ganus, Jr. sent HEW a long, detailed letter on behalf of Harding College, the Harding Graduate School of Religion, and the K-12 Harding Academy of Searcy. ${ }^{104}$ President Ganus indicated the institutions' willingness to comply with Title IX and its regulations "insofar as they do not violate our religious principles," but the institutions were "seeking exemption" for "areas which we feel are incompatible with Biblical principles." While BYU notified OCR of its inherent exemption and St. Charles

101. Letter from Vincent L. Burns, President, St. Charles Borromeo Seminary, to Dep't of Health, Educ., \& Welfare (Aug. 4, 1976), http://www2.ed.gov/about/offices/list/ocr/docs/t9-relexempt/st-charles-borromeo-seminary-overbrook-request-08041976.pdf.

102. Id.

103. Letter from Martin H. Gerry, Acting Dir., Office for Civil Rights, Dep't of Health, Educ., \& Welfare, to Reverend Monsignor Vincent L. Burns, President, St. Charles Borromeo Seminary (Sept. 14, 1976), http://www2.ed.gov/about/offices/list/ocr/docs/t9-rel-exempt/st-charles-borromeoseminary-overbrook-response-09141976.pdf.

104. Letter from Clifton L. Ganus, Jr., President, Harding Coll., to David Mathews, Sec'y, Dep't of Health, Educ., \& Welfare (July 21, 1976) [hereinafter Ganus Letter dated July 21, 1976], http://www2.ed.gov/about/offices/list/ocr/docs/t9-rel-exempt/harding-graduate-school-of-religionrequest-07211976.pdf.

105. Id. at 1 . 
Borromeo Seminary provided facts, Harding College presented its exemption claim as a request. It described itself as "a Christian institution, supported and operated by members of the church of Christ." "106 Two months later, Harding College again wrote to OCR, noting that it had received no reply on its "application for exemption." 107

When OCR responded, it initially described its responsibilities under the religious exemption procedures of Title IX as it had to BYU: to assure that institutions had "a full understanding of the provisions from which they believe themselves exempt." 108 But with Harding College, OCR expanded its own responsibility from fomenting full understanding of the regulations to also include 1) evaluation of the educational institution's qualification to apply for the exemption and 2) oversight of the specificity with which educational institutions identified inconsistencies between religious tenets and regulatory sections. ${ }^{109}$ Although it expanded its own responsibility, OCR did not fully exercise that authority with Harding College, but focused instead on the specificity of inconsistencies Harding College asserted between religious principles and particular regulatory sections. ${ }^{110}$ It did not assess whether Harding College was controlled by a religious organization sufficient to qualify it for exemption to Title IX, but assumed that it was, given the College's statement that it was "a Christian institution, supported and operated by members of the Church of Christ." 111 Throughout its response letter, OCR capitalized church in the phrase "Church of Christ." 112 By capitalizing church, rather than leaving it lower case as had Harding College in its exemption request letter, OCR created a proper noun and thus imbued "church of Christ" with more organizational structure and potential control than Harding College had initially asserted.

While OCR termed the College's exemption claim a request, it

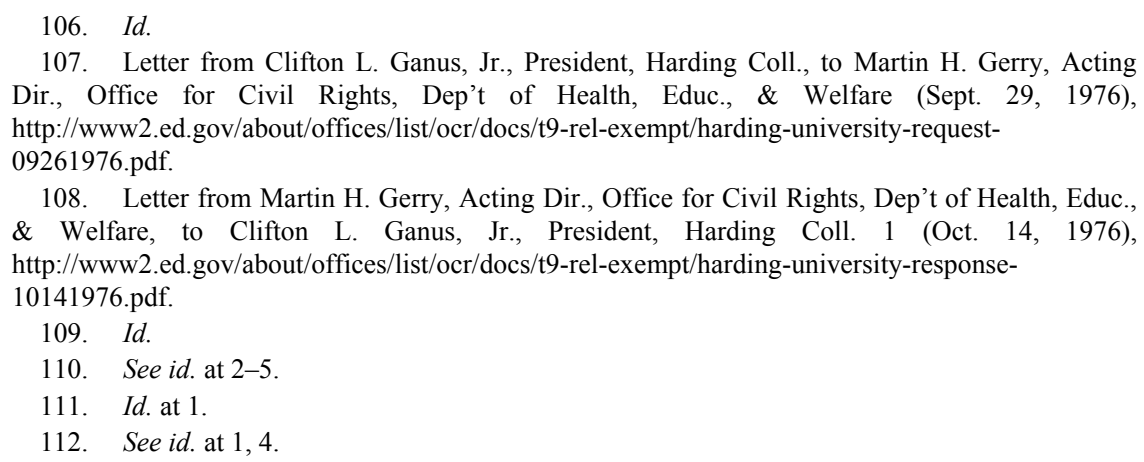


stopped there without noting a power it would later avow in 1985 to grant or deny the request. Rather, in language that sounded in inherent exemption rather than agency discretion, it concluded, "you are exempt," and "your financial aid program is exempt," and "your actions ... appear to comply with Title IX" with respect to a number of the exemption claims Harding College made. ${ }^{113}$ On points where Harding College represented it was bringing its differential policies for men and women into compliance with Title IX rather than seeking exemption-smoking, curfew, and security-OCR requested more information on timing. ${ }^{114}$

OCR found no exemption necessary for Harding College in two areas: intercollegiate women's athletic attire and homosexuality. ${ }^{115}$ Harding College pursued an "exemption on religious grounds from all women's sports which [Harding College] deem[s] to bring to [its] campus improper and suggestive attire." 116 The College had a longstanding policy that barred from campus "bands, athletes and other groups" from outside institutions "if they are accompanied by young ladies who are dressed in indecent uniforms, such as twirlers, majorettes, etc."117 OCR decided Harding College needed no exemption because nothing in Title IX prohibited the college from setting "even-handed" standards of dress and conduct for men and women on athletic teams and "making them conditions to be met by other teams seeking to compete with [the College]."118 With respect to Harding College's exemption claim to discriminate based on homosexuality, OCR disclaimed any relevance to Title IX: "Title IX does not address the question of homosexuality - it prohibits discrimination based on sex, not actions based upon sexual preference." ${ }^{\prime 19}$ OCR would later reassess that position and come to the opposite conclusion. In the 2010s, it recognized numerous exemption claims for educational institutions that discriminate based on homosexuality. ${ }^{120}$

In the back and forth, Harding College responded to OCR with appreciation for "the good spirit of [its] letter and the exemptions which

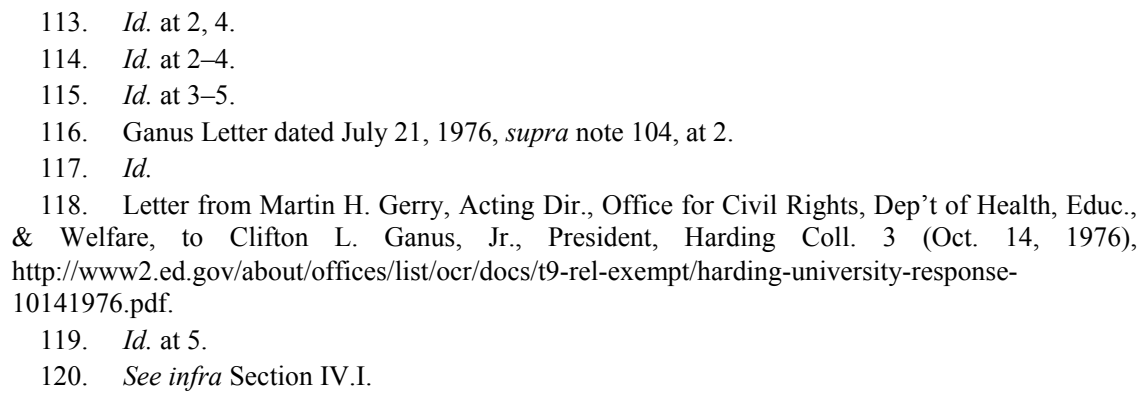


[it] ha[d] already granted."121 It provided information on timing: both men and women would be prohibited from smoking by August 1977; all men would be subject to the same curfew and security rules by the 1978 school year, but women would still be required to be in their dorms half an hour earlier to allow the men to escort the women home and still make their own curfew, something the College deemed "safer for our young ladies." 122 Most interestingly, Harding College rejected OCR's position that it did not need an exemption for intercollegiate women's sports because the College "could set standards of dress for visiting teams."123 The College thought setting such a standard "impossible" because "[n]o visiting team is going to have two sets of uniforms - one for the Harding campus and one for their other contests." ${ }^{24}$ The College had no difficulty with certain sports-golf, bowling, archery-where women's dress was modest, but it did "in those sports that utilize brief shorts for women." 125 Rather than asserting its inherent exemption, however, Harding College again "request[ed] a religious exemption in this area" and asked OCR to reconsider. ${ }^{126}$ Throughout its communication with HEW and OCR, Harding College took a more deferential approach than had BYU and St. Charles Borromeo Seminary. It sought, requested, and applied for exemption. OCR did not respond again to Harding College until $1985 .{ }^{127}$

\section{Policy Implications}

HEW recognized the religious exemption claims of BYU, St. Charles Borromeo, and Harding College before it articulated a standard, either in internal policy guidance memoranda or external publication, by which to resolve those claims. While the final religious exemption regulations provided procedure in 34 C.F.R. $\S 106.12(\mathrm{~b})$ and substance in $\S$ 106.12(a), both were lacking. Neither the regulations nor the statutory language of Title IX defined what constellation of facts constituted control by a religious organization sufficient for an educational

\footnotetext{
121. Letter from Clifton L. Ganus, Jr., President, Harding Coll., to Martin H. Gerry, Acting Dir., Office for Civil Rights, Dep't of Health, Educ., \& Welfare 1 (Jan. 3, 1977), http://www2.ed.gov/about/offices/list/ocr/docs/t9-rel-exempt/harding-university-request01031977.pdf.

122. Id.

123. Id. at 2 .

124. Id.

125. Id.

126. Id.

127. See infra Section IV.E.
} 
institution to claim the exemption. Moreover, in processing the three religious exemption claims in 1976, OCR did not discuss or comment on the assertion of control by a religious organization, even where the factual description and actual organizational structure might arguably fall short of an objective definition of control. In documenting the exemption claims, OCR largely treated the three educational institutions as inherently exempt, focusing on the specificity of religious tenets and regulatory sections, not on control by a religious organization.

\section{B. The Control Test, 1977}

The final version of 34 C.F.R. $\S 106.12(b)$, the regulatory procedure for claiming a religious exemption, had eliminated the requirement that claims for religious exemptions be made at the same time as the assurance of compliance required by $\S 106.4{ }^{128}$ Still, HEW initially linked the two procedures. The Office for Civil Rights drafted the "Assurance of Compliance" document, HEW Form 639-A, dated March 1977, to allow educational institutions to identify their religious exemption claim by checking a box on the form and then attaching the supporting statement from the highest ranking official. ${ }^{129}$ The instructions for HEW Form 639-A detailed the information that the educational institution should submit, hewing closely to the statute and regulations, but expanding beyond them to provide the missing definition of control by a religious organization, an essential element of Title IX and its regulations not otherwise delineated. ${ }^{130}$

The instructions to HEW 639-A explained that OCR would consider an educational institution to be "controlled by a religious organization" for purposes of a religious exemption to Title IX where:

(1) It is a school or department of divinity; or

(2) It requires its faculty, students or employees to be members of, or otherwise espouse a personal belief in, the religion of the organization by which it claims to be controlled; or

(3) Its charter and catalog, or other official publication, contains

128. Compare Education Programs and Activities Receiving or Benefiting from Federal Financial Assistance, 39 Fed. Reg. 22228, 22234 (proposed June 20, 1974) (codified at 45 C.F.R. pt. 86), with 34 C.F.R. § 106.12(b) (2015).

129. See Assurance of Compliance with Title IX of Education Amendments of 1972, 42 Fed. Reg. 15141 (Mar. 18, 1977).

130. Id. at $15142-43$. 
explicit statement that it is controlled by a religious organization or an organ thereof or is committed to the doctrines of a particular religion, and the members of its governing body are appointed by the controlling religious organization or an organ thereof, and it receives a significant amount of financial support from the controlling religious organization or an organ thereof.

OCR provided a more detailed definition of a "school or department of divinity," its first criteria for control, by citing a specific section of the Higher Education Act of 1965 as the definition's source. ${ }^{132}$ In contrast, for the second and third control criteria, the Office for Civil Rights made no citation to Title IX, any other statute or regulation, any judicial decision, or alternative source of legal authority, implying its own sole authority to establish what constitutes control sufficient for a religious exemption to Title IX. ${ }^{133}$ OCR published HEW 639-A and its instructions in the Federal Register in March 1977, but neither the form nor the control test it outlined were ever formalized as a regulation. ${ }^{134}$ The control test for religious exemptions to Title IX cannot be found in the Code of Federal Regulations nor, with the exception of its single appearance in the March 1977 Federal Register, had the Office for Civil Rights otherwise published it to the public prior to October 2015 when it posted the control test on its website. ${ }^{135}$ The control test began as and has remained an internal administrative agency policy and practice rather than a formalized statement of law or regulation. The March 1977 publication of HEW Form 639-A and its associated instructions provided the test for determining when a religious organization controlled an educational institution but provided no other standard by which OCR should consider a claim for religious exemption or whether OCR should engage in evaluation at all.

\footnotetext{
131. Id.

132. Id. (citing Higher Education Act of 1965, Pub. L. No. 89-329, § 111, 79 Stat. 1219, 1224).

133. In trying to determine how OCR developed the control test, I submitted a FOIA request for any documents from the Office of General Counsel; Litigation, Enforcement and Policy Service; and other legal offices in the Department that provided guidance or justification, or helped to create the instructions to HEW Form 639-A and the religious exemption control test it contains. See Email from Kif Augustine-Adams, Charles E. Jones Professor of Law, J. Reuben Clark Law Sch., Brigham Young Univ., to FOIA Pub. Liaison, Office of Mgmt./Office of the Chief Privacy Officer, EDFOIAManager@ed.gov (Aug. 18, 2015) (on file with author). The government was unable to locate any relevant documents. See Email from Christie D. Swafford, FOIA Pub. Liaison, Office of Mgmt./Office of the Chief Privacy Officer, to author (Oct. 2, 2015) (on file with author).

134. 134 Cong. ReC. 102 (1988) (statement of Sen. Orrin Hatch in Opposition to the Civil Rights Restoration Act of 1987).

135. In October 2015, OCR added to its website a statement on religious exemption to Title IX. See Office for Civil Rights, Religious Exemption, U.S. DEP'T EDUC. (June 30, 2016), https://www2.ed.gov/about/offices/list/ocr/frontpage/pro-students/rel-exempt-pr.html.
} 


\section{Agency Inaction-Institutional Self-Certification of Exempt Status, 1976-1985}

Between July 21, 1975, when the regulations became effective, and February 1985, when the Office for Civil Rights instituted the Religious Exemption Project to resolve unanswered claims, more than 200 educational institutions followed the procedure in 34 C.F.R. $\S 106.12$ (b) to formally assert a religious exemption to Title IX's non-discrimination requirements. ${ }^{136}$ Beyond LDS BYU in Utah, Catholic St. Charles Borromeo Seminary in Pennsylvania, and Church of Christ Harding College in Arkansas, the institutions ranged from Baptist Samford University in Alabama, to evangelical Christian Wheaton College in Illinois, to Quaker George Fox in Oregon, to The Catholic University of America in Washington D.C., to various rabbinical colleges and yeshivas in New York and New Jersey. ${ }^{137}$ Although the Office for Civil Rights received the more-than-200 pending claims prior to 1979 and the vast majority in 1976 and 1977, OCR responded on substantive grounds to only four exemption claims beyond BYU, St. Charles Borromeo, and Harding College prior to initiating the Religious Exemption Project in $1985 .^{138}$ In 1979, OCR made some efforts to gather additional information regarding exemption claims and sought Assurances of Compliance from religious educational institutions that had not submitted HEW Form 639-A. ${ }^{139}$ Those efforts resulted in seven Catholic undergraduate institutions receiving notice from OCR in early 1980 that they need not have requested a religious exemption in the first place because Title IX and 34 C.F.R. $\S 106.15$ did not prohibit the private, single-sex undergraduate education the institutions offered. ${ }^{140}$ On substantive grounds, between July 1975 and February 1985, OCR responded to only seven of the more than 200 religious exemption claims

136. See Memorandum re Completion of the Title IX Religious Exemption Project from Harry M. Singleton, Assistant Sec'y, Office for Civil Rights, U.S. Dep't of Educ., to Reg'l Dirs., Regions I-X, Office for Civil Rights, U.S. Dep't of Educ. 1 (Nov. 22, 1985) [hereinafter November 1985 REP Completion Memorandum] (on file with author); see also Memorandum re Policy Guidance for Resolving Religious Exemption Requests from Harry M. Singleton, Assistant Sec'y, Office for Civil Rights, U.S. Dep't of Educ., to Reg'l Dirs., Regions I-X, Office for Civil Rights, U.S. Dep't of Educ. (Feb. 19, 1985) [hereinafter February 1985 Policy Memorandum], http://www2.ed.gov/about/offices/list/ocr/docs/singleton-memo-19850219.pdf.

137. See November 1985 REP Completion Memorandum, supra note 136.

138. See Title IX Religious Exemption Database, supra note 12.

139. See, e.g., Letter from Norman Adrian Wiggins, President, Campbell Coll., to Waite H. Madison, Jr., Acting Dir., Div. of Postsecondary Educ., Office of Compliance \& Enf't, Office for Civil Rights, Dep't of Health, Educ., \& Welfare 1 (Feb. 25, 1979) (on file with author).

140. See Title IX Religious Exemption Database, supra note 12. 
educational institutions made. ${ }^{141}$

For nearly a decade, the Office for Civil Rights' inaction meant that, in essence, religious exemption claims existed as the U.S. Catholic Conference had proposed in its comments to the regulations: as selfcertifications of exempt status. ${ }^{142}$ The educational institutions asserted their exempt status as entities controlled by a religious organization and continued to discriminate in accordance with the religious tenets that they maintained conflicted with Title IX and its implementing regulations.

Various factors help explain OCR's inaction regarding religious exemption claims between 1975 and 1985. If OCR considered educational institutions controlled by religious organizations as inherently exempt, as BYU and St. Charles Borromeo Seminary asserted and OCR's 1976 recognition letters seem to imply, it may have perceived limited value in providing documentation of the exemption to additional institutions once it had rather publically acknowledged BYU's exemption. Except for the fact that BYU led out against the Title IX regulations, however, the documentary evidence provides few clues as to why OCR chose to address the claims made by BYU, St. Charles Borromeo, and Harding College rather than claims made by ninetyfour ${ }^{143}$ other institutions in 1975 and $1976 .{ }^{144}$

Similarly, if OCR's interaction with BYU or Harding College, rather than St. Charles Borromeo Seminary, set the pattern for resolving religious exemption claims, it is easy to see how OCR could have been overwhelmed by the number of claims it received and the length of time it took to respond to them. While OCR received only five religious exemption claims in 1975, in 1976 it received ninety-two, and in 1977 it received ninety-six. ${ }^{145}$

However long or short they took to resolve, religious exemption claims were a very low priority at OCR during the Carter Administration (1977-1981) and the first part of the Reagan Administration (1981-

\footnotetext{
141. See id.

142. See discussion supra notes $39-46$ and accompanying text.

143. See Memorandum re Application of the Religious Exemption Provision of Title IX of the Education Amendments of 1972 from Cynthia G. Brown, Co-Dir., Equal. Ctr., to Kitty Higgins, Minority Staff Dir., Senate Comm. on Labor \& Human Res. app. A (July 15, 1985) [hereinafter Equality Center Memorandum] (on file at Margaret Dunkle Papers, MC 530, folders 11.3-11.7, Item Nos. 11.6321-11.7351, Schlesinger Library, Radcliffe Inst., Harvard University).

144. See Title IX Religious Exemption Database, supra note 12.

145. Equality Center Memorandum, supra note 143, app. A.
} 
1989). ${ }^{146}$ Even so, inattention or low priority was not a charge unique to religious exemption claims or the most serious allegation of inaction OCR faced in the years immediately after passage of Title IX. OCR also failed to act on actual discrimination complaints under Title IX. A study the Project on Equal Education Rights (PEER) conducted in 1976 reviewed every sex discrimination complaint against an elementary or secondary school filed with OCR field offices from June 1972 to October 1976. ${ }^{147}$ OCR resolved only about $20 \%$ of the complaints and usually took years to do so. ${ }^{148}$ The study also alleged that in August 1976, OCR Director Martin Gerry - the government official who signed exemption letters for BYU, St. Charles Borromeo Seminary, and Harding College in August, September, and October 1976-imposed a moratorium on sex discrimination enforcement actions. ${ }^{149}$ Gerry did so by bringing the sex discrimination complaints that would usually be handled by the regional field offices into the main Washington, D.C. office for review. ${ }^{150}$ PEER alleged that the inaction on sex discrimination complaints was so extreme that for months, OCR "did not even answer its mail."151 After PEER published its study, OCR admitted that the study was an "essentially accurate analysis" of the four-year period studied, a timeframe in which OCR also received the bulk of the religious exemption claims still pending in $1985 .{ }^{152}$ Inaction was OCR's modus operandi, not just with respect to religious exemption claims, but Title IX generally.

\section{Mixing Institutional Entitlement and Agency Discretion-Ad Hoc \\ Resolution of Four Exemption Claims, 1983-1985}

In February 1983, Covenant Theological Seminary, the "official seminary of the Presbyterian Church in America," claimed a religious exemption, ${ }^{153}$ a claim to which OCR promptly responded, leapfrogging

\footnotetext{
146. See, e.g., id. at 7.

147. Project on Equal Educ. Rights, Stalled at the Start: Government Action on SEX Bias IN THE SCHOOLS 5 (1978).

148. Id. at 7 .

149. Id. at 36-37.

150. Id. at 36 .

151. Id. at 8 .

152. Bill Peterson, Women's Group Faults HEW on School Sex Bias, WASH. Post (Nov. 8, 1977) (quoting David S. Tatel, Director of the Office for Civil Rights), https://www.washingtonpost.com/archive/politics/1977/11/08/womens-group-faults-hew-on-schoolsex-bias/b7dfb3a2-5ca6-4657-a935-86dda1e412e6/.

153. Letter from William S. Barker, President, Covenant Theological Seminary, to Harry M. Singleton, Assistant Sec'y, Office for Civil Rights, U.S. Dep't of Educ. 1 (Feb. 23, 1983)
} 
over the 200 or so unacknowledged claims from previous years, which also included various seminaries. ${ }^{154}$ The documentary record does not clarify why OCR, then under the Reagan Administration, chose to respond to Covenant Theological Seminary with so many additional, similar claims pending or to act at all. In 1984, OCR would also address religious exemption claims made earlier by Saint John's University and Christian Heritage College, with at least the action regarding Saint John's University motivated by a complaint against the institution. ${ }^{155}$ OCR's response letter to Christian Heritage College became the template for future letters, including the language that an educational institution "adequately establishe[d]" control by a religious organization, ${ }^{156}$ language that would be repeated in OCR's recognition of Atlantic Christian College's claim for an exemption, a claim OCR recognized just prior to initiation of the Religious Exemption Project in February $1985 .^{157}$

\section{Covenant Theological Seminary}

OCR's communication with Covenant Theological Seminary regarding religious exemptions followed the pattern set by OCR's interaction with BYU and Harding College rather than the brief factual statement regarding St. Charles Borromeo Seminary. With respect to the required control by a religious organization, Covenant Theological Seminary simply stated that the Presbyterian Church in America controlled it, providing no additional detail. ${ }^{158}$ Covenant Theological Seminary was the first religious exemption claim that OCR recognized after articulating the control test in the instructions to HEW Form 639A. ${ }^{159}$

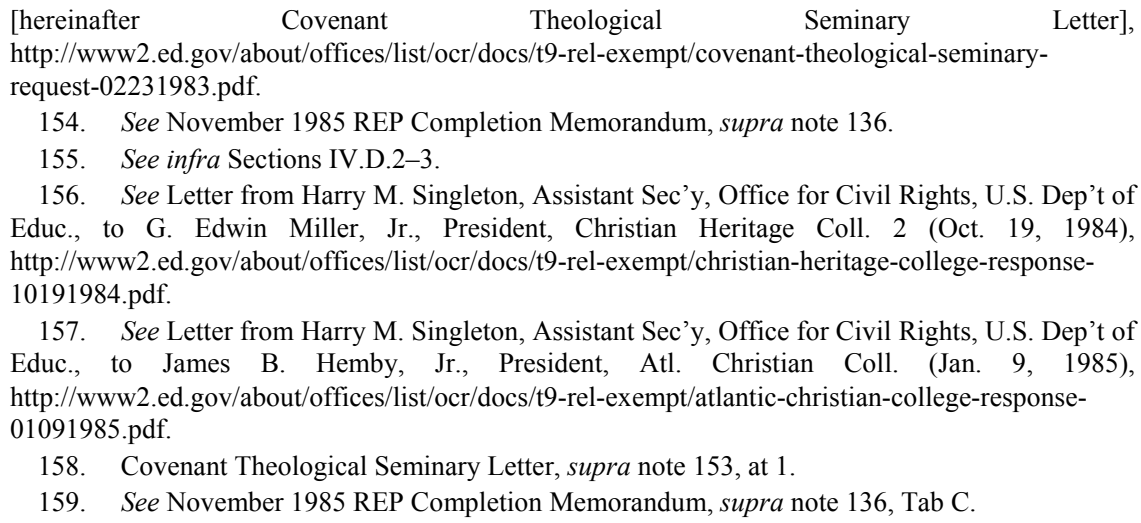

158. Covenant Theological Seminary Letter, supra note 153, at 1.

159. See November 1985 REP Completion Memorandum, supra note 136, Tab C. 
In its response letter, OCR acknowledged that Covenant Theological was the official seminary of the Presbyterian Church in America but made no finding or direct acknowledgement that the seminary met the first criterion in the control test of HEW Form 639-A. ${ }^{160}$ In future reviews of religious exemption claims, OCR adopted the same approach. A simple statement of control sufficed under any of the criteria, although institutions often provided much more information and detail, particularly in the 2010s.

Covenant Theological Seminary provided a detailed description of conflict between Presbyterian religious tenets and Title IX, a conflict which arose because Title IX required "equal treatment of women with regard to admission to those programs that are designed for the profession of the ordained ministry, and with regard to appointment of faculty members," when the Presbyterian Church in America held "the office of the ordained ministry open only to men."161 A citation to The Book of Church Order of the Presbyterian Church in America provided the doctrinal support for male-only ordained ministry, a doctrine "[i]n accord with Scripture."162 Although Covenant Theological Seminary did admit women for training for religious service not requiring ordination, its primary purpose was to train men for the ordained ministry. ${ }^{163}$

Based on a male-only ordained ministry, Covenant Theological Seminary argued it could not comply with six of the Title IX regulations regarding equal treatment of students (admission, recruitment, education programs and activities, "counseling and use of appraisal and counseling materials," financial assistance, and employment assistance to students) and five regulations regarding equal treatment of faculty and employees (employment, recruitment, job classification and structure, advertising, and pre-employment inquiries). ${ }^{164}$ Where St. Charles Borromeo admitted exclusively men to the seminary, a religious exemption for admissions precluded the need for exemptions to other Title IX regulations. Because no women students existed at St. Charles Borromeo Seminary, it did not treat men and women differently, differential treatment that could run afoul of Title XI absent a religious exemption. In contrast, where

160. Letter from Antonio J. Califa, Dir., Policy \& Enf't Serv., Office for Civil Rights, U.S. Dep't of Educ., to William S. Barker, President, Covenant Theological Seminary 1 (May 19, 1983), http://www2.ed.gov/about/offices/list/ocr/docs/t9-rel-exempt/covenant-theological-seminaryresponse-05191983.pdf.

161. Covenant Theological Seminary Letter, supra note 153, at 1.

162. Id.

163. Id. at $1-2$.

164. Id. at $2-3$. 
Covenant Theological Seminary admitted women for some limited purposes but not its primary purpose of training men for the male-only ordained ministry, it claimed religious exemptions for admissions as well as for the infrastructure that supported that ministry. ${ }^{165}$ Covenant Theological Seminary identified the depth of its commitment to a maleonly priesthood by claiming an exemption from providing equal employment assistance to female students "either directly or in assistance to any other agency, organization or person" because the religious tenets of the Presbyterian Church in America "forbid women to preach."166 It would not help its female students find ministry jobs, directly or indirectly, even in denominations that allowed women's ordination or preaching. ${ }^{167}$

While Covenant Theological Seminary described its action as a claim to exemption, OCR took a different rhetorical stance. In the fourand-a-half-page, single-spaced response letter, OCR used the term "request" twice to describe the seminary's actions but "claim" only once. ${ }^{168}$ More strikingly, OCR described its own actions as granting Covenant's request nine times, and accepting its claim only once. ${ }^{169}$ Using "request" and "grant" instead of "claim" and "accept" to describe their respective actions subtly, but forcefully, shifted power from the educational institution to OCR as the entity controlling religious exemptions to Title IX. OCR's grant of a request moved the religious exemption process back towards the review and qualify language that HEW eliminated from the draft regulations to Title IX in 1975.

Based on the information Covenant Theological Seminary provided regarding control and religious tenets, OCR granted exemptions to Title IX that allowed the institution to discriminate against women in student admissions, recruitment, educational programs and activities, counseling, and financial assistance, to the degree that male-only ordained ministry limited women's participation. ${ }^{170}$ OCR found no conflict, and thus, no need for an exemption, where Covenant Theological Seminary provided differential employment assistance, because female students simply

\footnotetext{
165. See id.

166. Id. at 3 .

167. See id.

168. See Letter from Antonio J. Califa, Dir., Policy \& Enf't Serv., Office for Civil Rights, U.S. Dep't of Educ., to William S. Barker, President, Covenant Theological Seminary (May 19, 1983), http://www2.ed.gov/about/offices/list/ocr/docs/t9-rel-exempt/covenant-theological-seminaryresponse-05191983.pdf.

169. See id.

170. Id. at $2-3$.
} 
could not "obtain appropriate credentials for certain employment opportunities" where the Presbyterian Church in America disallowed female ministers. ${ }^{171}$ Limiting employment assistance to students who had the appropriate credentials - however restricted the opportunity to obtain those credentials - did not require an exemption in OCR's view. ${ }^{172}$

For Covenant Theological Seminary's own employment practices, OCR granted two exemptions regarding job classification/structure and pre-employment inquiries regarding sex, exemptions limited to the requirements of a male-only priesthood. ${ }^{173}$ OCR found no conflict between the Title IX regulations and Covenant Theological's employment, recruiting, and advertising "to the extent that a position requires qualifications that only men possess, i.e., ordination to the ministry." 174 Thus, the Seminary could discriminate in faculty positions without running afoul of Title IX regulations because ordained ministers comprised the bulk of the faculty at an institution designed to train other men for that calling. The institution did not discriminate in staff positions because ordination was not required to support, rather than engage directly in, the core function of training men for the ministry. ${ }^{175}$

\section{Saint John's University}

A formal Title IX complaint against Saint John's University in 1983 prompted OCR action on the University's 1976 assertion of religious exemption. ${ }^{176}$ The complaint alleged Title IX violations in two areas: "the University's practice of preferring, in employment, members of Saint John's Abbey, the religious community that owns and controls the University," and when monks were not available, "the University's policy of hiring for the position of faculty resident in the dormitories for male undergraduate students, male, but not female, faculty members."

OCR's rhetorical stance in the Saint John's case was substantively different from its response to Covenant Theological Seminary's claim. Although in both cases OCR used language to grant the religious

\footnotetext{
171. Id. at 3 .

172. Id.

173. Id. at $4-5$.

174. Id. at 4 .

175. Covenant Theological Seminary Letter, supra note 153, at 2.

176. Letter from Harry M. Singleton, Assistant Sec'y, Office for Civil Rights, U.S. Dep't of Educ., to Kevin J. Hughes, Hughes, Thoreen and Sullivan, Att'ys \& Counsellors at Law, Saint John's Univ. (Mar. 9, 1984), http://www2.ed.gov/about/offices/list/ocr/docs/t9-rel-exempt/saintjohns-university-response-03091984.pdf.

177. Id. at 1 .
} 
exemption, OCR twice described Saint John's University as "entitled to a religious exemption" to Title IX. ${ }^{178}$ Except for the formal complaint against Saint John's University, there is no indication of factual differences in the educational institutions themselves, their control by a religious organization, or the articulation of their religious principles, that would entitle Saint John's to exemption but subject Covenant Theological Seminary or any other educational institution to agency discretion. OCR's response to Saint John's University is the only time in an exemption recognition letter the Office described an educational institution as entitled to religious exemption under Title IX. Entitlement sounds in inherent exemption rather than agency discretion.

Although there appears to be no material, factual differences between Saint John's University and Covenant Theological Seminary in their exemption claims, the complaint against Saint John's employment practices meant that OCR's Policy and Enforcement Service involved itself in recognizing Saint John's exemption in ways it did not for others. In fact, the "entitled to" language for Saint John's comes from legal analysis attorney Antonio J. Califa, Director of OCR's Policy and Enforcement Service, provided to the Assistant Secretary. ${ }^{179}$ Califa arrived at the conclusion that Saint John's was legally entitled to a religious exemption through an analysis of the legislative history of Title IX, congressional intent, and a Supreme Court decision, rather than application of the administrative control test set out in HEW Form 639-A or any other internal OCR policy or practice. ${ }^{180}$ Califa grounded his analysis in law rather than policy and administrative practice. Califa was also the agency official at the Office for Civil Rights who signed the exemption recognition letter for Covenant Theological Seminary, although 34 C.F.R. $\S 106.12$ (b) called for the Assistant Secretary to receive statements of religious exemption. ${ }^{181}$

178. Id. at $1-2$

179. Memorandum re Saint John's University - Request for Religious Exemption from Title IX from Antonio J. Califa, Dir., Policy \& Enf't Serv., Office for Civil Rights, U.S. Dep't of Educ., to Harry M. Singleton, Assistant Sec'y, Office for Civil Rights, U.S. Dep't of Educ. (undated; circa late Feb./early Mar. 1984) (on file with author).

180. See id.

181. See Letter from Antonio J. Califa, Dir., Policy \& Enf't Serv., Office for Civil Rights, U.S. Dep't of Educ., to William S. Barker, President, Covenant Theological Seminary (May 19, 1983), http://www2.ed.gov/about/offices/list/ocr/docs/t9-rel-exempt/covenant-theological-seminaryresponse-05191983.pdf; see also 34 C.F.R. § 106.12(b) (2015). Although, as Director for OCR's Policy and Enforcement Service, Antonio Califa worked for Assistant Secretary Singleton, they experienced significant tensions in their relationship and approach to civil rights. Steve Twomey, Singleton's Disputed Record, WASH. POST (Oct. 25, 1990), https://www.washingtonpost.com/archive/politics/1990/10/25/singletons-disputed-record/cf2edd71- 


\section{Christian Heritage College}

While there does not appear to be a complaint against Christian Heritage College, OCR acted in 1984 on the exemption the College originally claimed in $1979 .{ }^{182}$ For the first time in its response letter, OCR stated that the facts the College presented "adequately establishe[d]" the control by a religious organization necessary for exemption to Title IX, the language that became standard in future determinations of control through the turn of the twenty-first century. ${ }^{183}$

Christian Heritage College sought and received from OCR broad exemption from Title IX regulations to allow it to discriminate in consonance with its religious principles regarding separate roles for men and women, men's authority over women at the college and in the home, and extra-marital sex. ${ }^{184}$ Among other things, the exemptions allowed the college to limit ministerial programs and classes to men; limit home economics courses to women; counsel and assist men and women students differently in career and life planning; inquire about and make decisions based on marital/parental status; reserve certain campus employment to men; and deny employment to a woman where that employment conflicted with her family responsibilities and submission to her husband. ${ }^{185}$

The tone and rhetoric of OCR's recognition letter to Christian Heritage College differed significantly from its letters to Covenant Theological Seminary and Saint John's University, both letters influenced by Antonio Califa. In contrast to the entitlement language in

a733-4f25-9572-1571176606b0/.

182. Letter from Henry M. Morris, President, Christian Heritage Coll., to Benjamin Saunders, Div. of Postsecondary Educ., Office of Compliance \& Enf't, Office for Civil Rights, Dep't of Health, Educ., \& Welfare (Mar. 28, 1979), http:/www2.ed.gov/about/offices/list/ocr/docs/t9-relexempt/christian-heritage-college-request-03281979.pdf; Letter from Harry M. Singleton, Assistant Sec'y, Office for Civil Rights, U.S. Dep't of Educ., to G. Edwin Miller, Jr., President, Christian Heritage Coll. (Oct. 19, 1984), http://www2.ed.gov/about/offices/list/ocr/docs/t9-relexempt/christian-heritage-college-response-10191984.pdf. Christian Heritage College became San Diego Christian College in 2005. About San Diego Christian College, SAN Diego Christian C., http://sdcc.edu/about/ (last visited Nov. 22, 2016).

183. Letter from Harry M. Singleton, Assistant Sec'y, Office for Civil Rights, U.S. Dep't of Educ., to G. Edwin Miller, Jr., President, Christian Heritage Coll. 2 (Oct. 19, 1984), http://www2.ed.gov/about/offices/list/ocr/docs/t9-rel-exempt/christian-heritage-college-response10191984.pdf.

184. Id. at 2-3.

185. Id.; see also Letter from Henry M. Morris, President, Christian Heritage Coll., to Benjamin Saunders, Div. of Postsecondary Educ., Office of Compliance \& Enf't, Office for Civil Rights, Dep't of Health, Educ., \& Welfare 3-9 (Mar. 28, 1979), http://www2.ed.gov/about/offices/list/ocr/docs/t9rel-exempt/christian-heritage-college-request-03281979.pdf. 
the recognition letter to Saint John's University and the subtle rhetorical shift of power in the letter to Covenant Theological Seminary, the letter to Christian Heritage College was blunt. The Assistant Secretary wrote to Christian Heritage "to inform [it] of [his] decision regarding [its] request for a religious exemption from certain requirements of Title IX." " The Assistant Secretary's letter appropriated authority to the agency; OCR informed, decided, granted religious exemption requests to educational institutions that could meet the burden of "adequately establish[ing]" their qualifications. ${ }^{187}$ While in practice that burden was minimal, it and OCR's rhetorical stance eroded both the presumption of inherent exemption that BYU posited and OCR accepted for religious educational institutions in 1976 and the entitlement language that OCR used for Saint John's University in 1984.

\section{Atlantic Christian College}

Atlantic Christian College began its formal August 1984 exemption request with a plea that OCR respond: "It is very important that we have your decision at the earliest possible time." "I88 In 1984, Atlantic Christian College's claim to exemption had been pending only since early $1982,{ }^{189}$ for two and a half years, not for nearly a decade as had claims made in the mid-1970s. Sometime prior to February 1982, Atlantic Christian College had sought OCR's review of its custom of removing from oncampus housing women who became pregnant, whether the women were married or unmarried. ${ }^{190}$ By 1984, Atlantic Christian's request for exemption to Title IX was more limited, more direct, and more fully grounded in religious principle rather than in previously expressed concerns for the woman's health. The president "respectfully request[ed] that Atlantic Christian College be allowed to prohibit unmarried pregnant

186. Letter from Harry M. Singleton, Assistant Sec'y, Office for Civil Rights, U.S. Dep't of Educ., to G. Edwin Miller, President, Christian Heritage Coll. 1 (Oct. 19, 1984), http://www2.ed.gov/about/offices/list/ocr/docs/t9-rel-exempt/christian-heritage-college-response10191984.pdf.

187. Id. at $2-4$.

188. Letter from James B. Hemby, Jr., President, Atl. Christian Coll., to William Thomas, Reg'l Dir., Region IV, Office for Civil Rights, U.S. Dep't of Educ. (Aug. 29, 1984), http://www2.ed.gov/about/offices/list/ocr/docs/t9-rel-exempt/atlantic-christian-college-request08291984.pdf.

189. Lisa Boykin, Custom Regarding Pregnancy Reviewed, Collegiate (Atl. Christian Coll. newspaper), Feb. 3, 1982, at 1, http://newspapers.digitalnc.org/lccn/2014236903/1982-02-03/ed1/seq-1.pdf (noting Atlantic Christian College's custom of not allowing pregnant women to live in the dormitories was under Title IX review in Washington, D.C.).

190. Id. 
females from maintaining residence in [its] College dormitories."191 Beyond their own violation of religious prohibitions on extra-marital sex, unmarried pregnant women's living in the dormitories "defines for the other women living in those dormitories undesirable moral and ethical principles." 192

Atlantic Christian described itself as founded and sponsored by the Christian Church (Disciples of Christ). ${ }^{193}$ That description, along with the additional detail that "[f]ive ministers of the church, including the regional minister of North Carolina" "194 served on the institution's Board of Trustees "adequately establish[ed]," in OCR's judgment, control by a religious organization. ${ }^{195}$ Using the same language as it had with Christian Heritage College, the Assistant Secretary for Civil Rights informed the College of his decision to grant the requested exemptions. ${ }^{196}$ OCR's choice of language emphasized its authority at the expense of the College's inherent exemption.

\section{E. The Religious Exemption Project, 1985}

In February 1985, the Office for Civil Rights implemented the

191. Letter from James B. Hemby, Jr., President, Atl. Christian Coll., to William Thomas, Reg'l Dir., Region IV, Office for Civil Rights, U.S. Dep't of Educ. (Aug. 29, 1984), http://www2.ed.gov/about/offices/list/ocr/docs/t9-rel-exempt/atlantic-christian-college-request08291984.pdf.

192. Id.

193. Id.

194. Letter from James B. Hemby, Jr., President, Atl. Christian Coll., to William H. Thomas, Reg'l Dir., Region IV, Office for Civil Rights, U.S. Dep't of Educ. 1 (Oct. 17, 1984), http://www2.ed.gov/about/offices/list/ocr/docs/t9-rel-exempt/atlantic-christian-college-request10171984.pdf.

195. Letter from Harry M. Singleton, Assistant Sec'y, Office for Civil Rights, U.S. Dep't of Educ., to James B. Hemby, Jr., President, Atl. Christian Coll. 1 (Jan. 9, 1985), http://www2.ed.gov/about/offices/list/ocr/docs/t9-rel-exempt/atlantic-christian-college-response01091985.pdf.

196. Id. The primary difference between OCR's treatment of Christian Heritage College and Atlantic Christian College is that OCR asked Atlantic Christian for more information regarding its controlling institution and for more detail on its religious tenets. See Letter from James B. Hemby, Jr., President, Atl. Christian Coll., to William H. Thomas, Reg'l Dir., Region IV, Office for Civil Rights, U.S. Dep't of Educ. 1 (Oct. 17, 1984), http://www2.ed.gov/about/offices/list/ocr/docs/t9-relexempt/atlantic-christian-college-request-10171984.pdf. Responding to that request, Atlantic Christian added the detail about the five ministers serving on the Board of Trustees as well as a statement that "[t]he Disciples do not have specifically stated religious tenets; therefore, the information you requested cannot be provided at the level of specificity you requested." Id. That professed lack of specificity did not deter OCR from recognizing the exemption claim. Letter from Harry M. Singleton, Assistant Sec'y, Office for Civil Rights, U.S. Dep't of Educ., to James B. Hemby, Jr., President, Atl. Christian Coll. (Jan. 9, 1985), http://www2.ed.gov/about/offices/list/ocr/docs/t9-rel-exempt/atlantic-christian-college-response01091985.pdf. 
Religious Exemption Project to clear the backlog of pending exemption claims. ${ }^{197}$ What motivated the Reagan Administration's OCR to "systematically process all the outstanding requests" was not clear even at the time or to those who were directly involved. ${ }^{198}$ Nonetheless, nearly ten years after the regulations became effective, the Religious Exemption Project resulted in the first policy guidance memorandum that OCR developed to resolve religious exemption claims. ${ }^{199}$ On its face, the policy emphasized agency discretion rather than inherent exemption, even though the underlying standard of review deferred significantly to educational institutions' presentation of themselves and their factual assertions. ${ }^{200}$

\section{Policy Guidance for Resolving Religious Exemption Requests}

Rather than reviewing the exemption requests and responding to them directly as OCR had done with the seven claims it previously recognized, OCR farmed the more than 200 pending exemption claims out to the ten regional civil rights offices for initial staff work, information gathering, and response letter drafting. ${ }^{201}$ The Assistant Secretary for Civil Rights himself still planned to sign the final response letters after review by OCR's Policy and Enforcement Service, but outsourcing the supporting work made the 180 day turn around the Assistant Secretary requested - after a ten year delay in some cases-at least potentially realistic. ${ }^{202}$ In the end, OCR completed the Religious Exemption Project in nine months rather than six, resolving all of the pending claims by November $1985 .^{203}$

With ten different regional offices considering religious exemption claims, uniform policy guidance for resolving those requests was imperative. The February 1985 Policy Memorandum for Resolving Religious Exemption Requests set forth that guidance under the signature

\footnotetext{
197. Telephone Interview with Valerie McMurtrie Bonnette, former OCR policy analyst and coordinator for the Religious Exemption Project in 1985 (May 11, 2015) (notes on file with author); see also Equality Center Memorandum, supra note 143, at 7; February 1985 Policy Memorandum, supra note 136 , at 1.

198. Equality Center Memorandum, supra note 143, at 7; see also Telephone Interview with Valerie McMurtrie Bonnette, supra note 197.

199. See Telephone Interview with Valerie McMurtrie Bonnette, supra note 197; see also February 1985 Policy Memorandum, supra note 136.

200. See February 1985 Policy Memorandum, supra note 136.

201. Id. at 1 .

202. Id.

203. November 1985 REP Completion Memorandum, supra note 136, at 1.
} 
of the Department of Education's Assistant Secretary for Civil Rights, Harry M. Singleton, ${ }^{204}$ who left the Office for Civil Rights on December 31, 1985, six weeks after the Religious Exemption Project completed. ${ }^{205}$

\section{a. Standard of Review}

34 CFR § 106.12(b) provided that an educational institution that "wishe[d] to claim" an exemption, should do so by submitting in writing "a statement by the highest ranking official of the institution."206 Although the regulations use the words "claim" and "statement," the February 1985 memorandum termed the pending claims "requests" that OCR would either "grant or deny."207 OCR used the terms "request," "grant," "deny," and "decide" almost fifty times in the February 1985 memorandum. ${ }^{208}$ Not once did it use "claim," "statement," or "entitled" to describe the educational institution's action. ${ }^{209}$

Despite this rhetorical appropriation of authority, OCR instructed its regional offices to use a highly deferential standard of review, ${ }^{210}$ so deferential in fact that the process could barely be considered a review, although it does not appear that many educational institutions were aware of this deferential standard. ${ }^{211}$ The February 1985 memorandum prohibited staffers from conducting "any investigative activity" whatsoever to verify that the information educational institutions submitted with their claims was correct. ${ }^{212}$ In certain circumstances, regional offices could gather additional information, but once provided, all information was to be "accepted as fact.", 13 Whatever they did, regional offices should not contact the controlling religious organization

\footnotetext{
204. February 1985 Policy Memorandum, supra note 136.

205. Twomey, supra note 181.

206. 34 C.F.R. § 106.12(b) (2015).

207. February 1985 Policy Memorandum, supra note 136, at 1.

208. See id. at 1-7, Tab A, Tab B, Tab C, Tab D.

209. See id.

210. See id. at $1-7$.

211. Of all the post-Religious Exemption Project exemption claims, only BYU and BYUHawaii cite the February 1985 Policy Memorandum as guiding OCR's decision making process regarding religious exemption to Title IX. See Letter from Jeffrey R. Holland, President, Brigham Young Univ., to LeGrees [sic] Daniels, Assistant Sec'y, Office for Civil Rights, U.S. Dep't of Educ. 3 (Nov. 17, 1988), http://www2.ed.gov/about/offices/list/ocr/docs/t9-rel-exempt/brigham-younguniversity-utah-request-11171988.pdf; Letter from Alton L. Wade, President, Brigham Young Univ.-Haw., to LeGrees [sic] Daniels, Assistant Sec'y, Office for Civil Rights, U.S. Dep't of Educ. 2 (Mar. 21, 1989), http://www2.ed.gov/about/offices/list/ocr/docs/t9-rel-exempt/brigham-younguniversity-hawaii-request-03211989.pdf.

212. February 1985 Policy Memorandum, supra note 136, at 2.

213. Id. at $1-2$.
} 
itself "to confirm either control over the [educational] institution or the tenets followed by the organization." 14 Doing so "would be obtrusive." 215

Overall, the February 1985 memorandum recommended that regional offices "exercise leniency" in considering the claims. ${ }^{216}$ In OCR's view, the exemption claims merited leniency because the educational institutions claiming the exemptions "make no secret of the religious tenets that influence the institution and potential faculty and students are aware of this influence upon joining the institution community."217 OCR's position suggested that individuals who joined a religious educational community already aware of the discrimination it practiced, consented to it.

b. Control

At Tab B, the February 1985 memorandum included the instructions for HEW Form 639-A, instructions that defined control by a religious organization for purposes of an exemption to Title IX. ${ }^{218}$ Under the policy set forth in the February 1985 memorandum, however, the control test was not meant to actually control but instead to "guide[]" OCR staffers as they processed exemption claims. ${ }^{219}$ Regional offices "should not assume a strict interpretation" of the test, but rather "accept as fact" the existence of the required control "where the specific organization is named even when no information is provided on how that organization controls the institution., ${ }^{, 20}$ In other words, to pass the test, an educational institution need not even use the word "control" as long as it identified a religious organization. The highly deferential standard applied in an ad hoc manner to BYU, St. Charles Borromeo Seminary, and Harding College - the three claims recognized before HEW Form 639-A set forth the control test in 1977-and to Covenant Theological Seminary, Saint John's University, Christian Heritage College, and Atlantic Christian College - the four claims recognized after 1977became official policy. ${ }^{221}$ Whatever the control test was initially meant

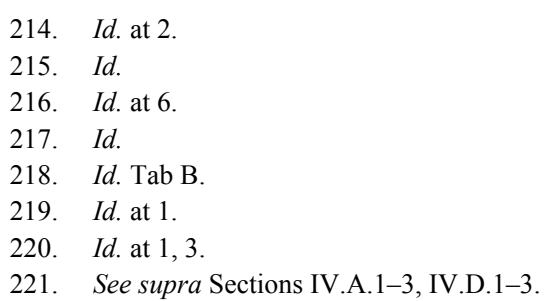


to be, as applied, it did not end up meaning much.

\section{c. Religious Tenets}

With respect to religious tenets, the February 1985 memorandum insisted that OCR not question the beliefs educational institutions claimed. $^{222}$ Some institutions offered Bible verses or cited other religious documents, which staffers could check for correct transcription only, nothing more. ${ }^{223}$ "Under no circumstances should OCR appear to be interpreting the Bible." ${ }^{, 24}$ More problematic for OCR review were institutions that failed to provide specific support for their religious beliefs but made broad allusions to "“Christian' or 'biblical morals.",225 The February 1985 memorandum instructed regional offices to accept even "these very general tenets" for exempting compliance "regarding marital and parental status of students and employees" because the particular regulatory sections were straightforward. ${ }^{226}$ But, OCR said it wanted staffers to ask the educational institutions for more specific descriptions of religious tenets where more complex regulatory sections were at issue. ${ }^{227}$ On their face, however, other regulatory sections that govern non-discrimination in athletics, access to classes and educational programs, do not seem more complex nor do the marital and parental status sections appear more straightforward. Rather, "Christian" and "biblical morals" prohibiting pre-marital and extra-marital sex were perhaps more familiar, better known as part of a changing American cultural landscape, than other religious tenets that might limit gender roles and women's more general participation in certain religious educational institutions.

\section{d. Procedures and Other Considerations}

Beyond control and religious tenets - the substantive elements of a religious exemption to Title IX-the February 1985 Policy Memorandum set forth procedural and other considerations for resolving the claims. ${ }^{228}$ Some institutions had been less than specific regarding the

\footnotetext{
222. February 1985 Policy Memorandum, supra note 136, at 3.

223. Id.

224. Id.

225. Id.

226. Id.

227. Id.

228. Id. at $1-7$.
} 
particular regulatory sections from which they claimed exemptions. ${ }^{229}$ Others had mistakenly claimed an exemption under one section rather than another. ${ }^{230}$ Some institutions claimed exceptionally broad exemptions without specifying the educational program to which the claim applied. $^{231}$ OCR advised its regional offices to draft response letters that corrected these mistakes in a minimal manner if at all, a manner that limited rather than expanded the scope and number of exemption claims. ${ }^{232}$

Where insufficient information existed in the claim, OCR instructed the regional offices to request the necessary information from the institution. $^{233}$ If the institution failed to provide the information, the regional office should draft a letter to the institution closing the exemption file. ${ }^{234}$ If the institution provided the requested information or where sufficient information already existed, the regional office should prepare a draft letter for the Assistant Secretary's signature either "granting" or "denying" the claim, as OCR asserted agency authority. ${ }^{235}$ In some cases, an institution need not have submitted a request for an exemption at all, because Title IX already allowed the particular practice at issue, even if it would otherwise be described as discriminatory. ${ }^{236}$ For example, Title IX allowed private undergraduate institutions-but not graduate programs - to admit only individuals of one sex. ${ }^{237}$ OCR maintained that graduate programs that admitted only a single sex "must submit a religious exemption request," again emphasizing that the administrative agency held authority to determine religious exemptions despite its highly deferential standard of review. ${ }^{238}$

\section{Policy Implementation Through the Religious Exemption Project}

OCR indeed exercised leniency when reviewing claims under the highly deferential standard it articulated in the February 1985 memorandum. By the end of the project in November 1985, OCR had

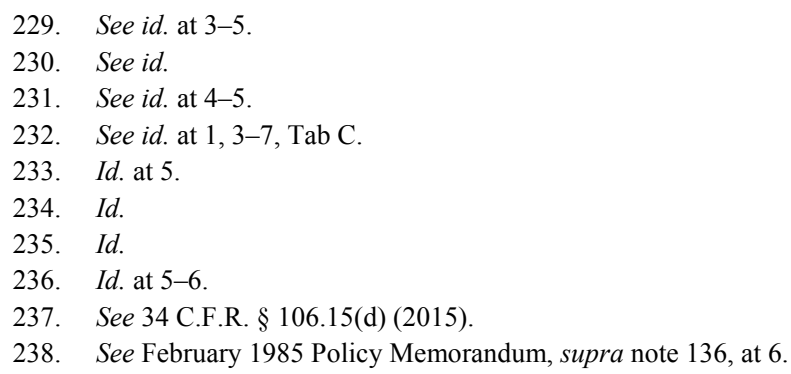


granted exemptions to 142 institutions and administratively closed seventy-nine claim files because the institution no longer existed, withdrew its exemption claim, failed to communicate with OCR, or no exemption was necessary. ${ }^{239}$ As part of the Religious Exemption Project, OCR denied no claims to a religious exemption under Title IX, nor, as of its September 15, 2016 website update, has it ever done so. ${ }^{240}$

\section{a. Claims Granted}

When OCR began the Religious Exemption Project to clear the backlog of claims, it had already considered and recognized exemptions for the seven institutions discussed above: Brigham Young University, St. Charles Borromeo Seminary, Harding College, Covenant Theological Seminary, Saint John's University, Christian Heritage College, and Atlantic Christian College. In granting exemptions on the 135 other claims, the OCR regional offices followed the February 1985 memorandum to a $\mathrm{T}$. Each of the exemption recognition letters followed the draft format, inserting into the set structure specific facts regarding control, conflicting religious tenets, and regulatory sections as recited by the claimant educational institution. While some institutions provided detailed descriptions to meet the control test, others named the controlling institution and no more. Some institutions recited doctrinal creeds and cited supporting scripture; others were less expansive.

\section{i. Finding Control}

The language of the statute, regulations, and control test all suggest by their grammatical structure that two different entities must be involved to manifest the required control for religious exemption to Title IX: a religious organization that exerts control and an educational institution that receives it. In its application of the control test during the Religious Exemption Project, however, OCR did not insist on two separate entities, nor did it even require that control be exercised by an organization despite the explicit statutory language. At times, educational institutions themselves denied that they were controlled by a separate religious organization; OCR nonetheless found sufficient control. On occasion, OCR sought more information regarding various

239. See November 1985 REP Completion Memorandum, supra note 136, Tab C; see also Title IX Religious Exemption Database, supra note 12.

240. Title IX Religious Exemption Database, supra note 12. 
educational institutions' controlling religious organization, but whatever additional information it received, OCR found for exemption.

a) "Controlled, Conducted and Operated by the Orthodox Jewish Religion"

Between 1975 and 1977, fifty-three Orthodox Jewish educational institutions claimed religious exemption to Title IX in a form letter, personalized only by their institution's letterhead and address. ${ }^{241}$ Fortynine of the claims came in 1977; thirty-three of the letters bore the same date, May 3, 1977. ${ }^{242}$ The vast majority of the letters described the educational institution as "controlled, conducted and operated by the Orthodox Jewish religion." ${ }^{243}$ Seven institutions including Beth Medrash Govoha defined both control and organizational structure more specifically. ${ }^{244}$ Each stated it "was chartered and is maintained as an Orthodox Jewish Seminary" whose "Trustees are mandated to conduct all its operations in strict accordance with Orthodox Jewish religious tenets." 245

While the statement "controlled, conducted and operated by the Orthodox Jewish religion" in the majority of letters identified a religion, it does not name an organization. ${ }^{246}$ There are, of course, organizations that identify as Orthodox Jewish, including Agudath Israel of America which appears to have helped coordinate the form letter and simultaneous religious exemption claims of so many educational institutions. Beth Medrash Govoha, as a seminary and through its trustees, is another. ${ }^{247}$ It is hard structurally, though, to characterize a

241. See Title IX Religious Exemption Database, supra note 12.

242. See id.

243. See, e.g., Letter from Sarah Freifeld, Dean, Ayelet Hashachar Teacher's Seminary for Women \& Inst. for Jewish Studies, to Dir., Office for Civil Rights, Dep't of Health, Educ., \& Welfare (May 3, 1997), http://www2.ed.gov/about/offices/list/ocr/docs/t9-rel-exempt/ayelethashachar-teachers-seminary-request-05031977.pdf.

244. See Title IX Religious Exemption Database, supra note 12.

245. See, e.g., Letter from Rabbi Y.J. Weisberg, Admin. Dean, Beth Medrash Govoha, to Dir., Office for Civil Rights, Dep't of Health, Educ., \& Welfare (Dec. 5, 1975), http://www2.ed.gov/about/offices/list/ocr/docs/t9-rel-exempt/beth-medrash-govoha-request12051975.pdf.

246. See, e.g., Letter from Sarah Freifeld, Dean, Ayelet Hashachar Teacher's Seminary for Women \& Inst. for Jewish Studies, to Dir., Office for Civil Rights, Dep't of Health, Educ., \& Welfare (May 3, 1997), http://www2.ed.gov/about/offices/list/ocr/docs/t9-rel-exempt/ayelethashachar-teachers-seminary-request-05031977.pdf.

247. Letter from Rabbi Y.J. Weisberg, Admin. Dean, Beth Medrash Govoha, to Dir., Office for Civil Rights, Dep't of Health, Educ., \& Welfare (Dec. 5, 1975), http://www2.ed.gov/about/offices/list/ocr/docs/t9-rel-exempt/beth-medrash-govoha-request- 
religion as an organization. By definition, the word organization means something different than the word religion; hence the use of the adjectival religious to identify the type of controlling organization that made an educational institution eligible for exemption. Nonetheless, for all who offered it, OCR accepted the statement of control, conduct, and operation by the Orthodox Jewish religion as "adequately establish[ing]" control by a religious organization for purpose of exemption to Title $\mathrm{IX}^{248}$ OCR did not request additional information regarding the controlling religious organization from any of the Orthodox Jewish claimants nor insist that they describe an organization as Beth Medrash Govoha had done, rather than identifying a religion.

\section{b) "Commitment to Christianity"}

Where educational institutions cited Christian religious principles as controlling, OCR was more likely than it had been with the Orthodox Jewish institutions to request additional information about organizational structure, although it did not insist on a controlling religious organization separate from the educational institution's leadership itself. When OCR asked Berea College to provide "the name of the religious organizations" that controlled it, Berea responded "'none', [sic] unless our Board of Trustees can be so identified." 249 OCR agreed that it could. ${ }^{250}$ In OCR's words, the serious commitment of Berea College and its controlling Board of Trustees to Christianity-expressed through its original charter, constitution, program and pronouncements - "adequately establishe[d] that Berea College is controlled by a religious organization." 251

That pattern repeated itself on various occasions. An educational institution would cite Christianity or biblical principles as motivating and guiding its endeavor, but either not name a specific controlling organization or pointedly assert its own independence. OCR would request more information and, based on the information provided, find a controlling religious organization in the institution's own board of trustees or board of directors or construct collective control through a

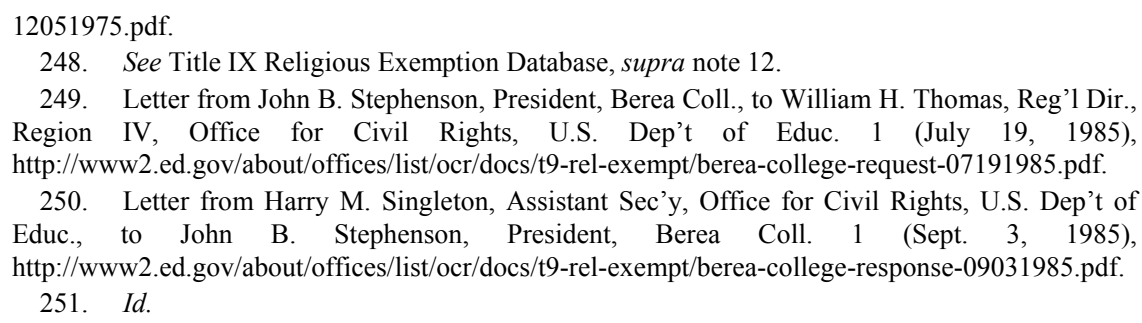


group of churches that contributed financially to the educational institution or through the statements of faith to which the institution required faculty and staff to ascribe, or some similar factual combination. Like Berea College, Colorado Christian University denied a controlling religious organization independent of its own self: "Please be advised that Colorado Christian College is an independent, non-sectarian evangelical Christian College. It is not sponsored by any specific religious organization, denomination, or sect."252 Rather than denying Colorado Christian's exemption claim for lack of a controlling religious organization, however, OCR gathered more information. ${ }^{253}$ In a telephone conversation, Colorado Christian University clarified control by its "Board of Trustees, whose members must sign the College's Statement of Faith," "financial support from a large number of Christian churches," required profession of Christianity and church activity for students, and church-vocational employment for more than half the graduates. $^{254}$ In those facts, OCR found sufficient control by a religious organization. $^{255}$ It might take some digging, but OCR elicited the necessary facts to evince control.

In 1985, Biola University described itself as a "private Christian evangelical institution governed by its Board of Trustees" in accordance with its "statement of purpose and mission and Articles of Faith contained within its Articles of Incorporation," citing its IRS designation

252. Letter from Joe L. Wall, President, Colo. Christian Coll., to Gilbert D. Roman, Reg'l Dir., Office for Civil Rights, U.S. Dep't of Educ. 1 (Sept. 18, 1985), http://www2.ed.gov/about/offices/list/ocr/docs/t9-rel-exempt/colorado-christian-college-request09181985.pdf.

253. See Letter from Harry M. Singleton, Assistant Sec'y, Office for Civil Rights, U.S. Dep't of Educ., to Joe L. Wall, President, Colo. Christian Coll. 1 (Oct. 25, 1985), http://www2.ed.gov/about/offices/list/ocr/docs/t9-rel-exempt/colorado-christian-college-response10251985.pdf.

254. Id.; $c f$. Letter from Harry E. Fletcher, President, Wash. Bible Coll., to LeGree S. Daniels, Assistant Sec'y, Office for Civil Rights, U.S. Dep't of Educ. 1 (Dec. 21, 1988), http://www2.ed.gov/about/offices/list/ocr/docs/t9-rel-exempt/washington-bible-college-capital-bibleseminary-request-12211988.pdf ("While our institution is not under the direct control of a religious organization, our purpose is to serve Christ and His church by providing undergraduate and graduate biblical and professional education that will equip men and women for Christian ministry worldwide; and by serving as a biblical and theological resource center for the equipping of Christian laymen and for the continuing education of pastors, missionaries, and other Christian workers. Each year the Board of Trustees, administrative officers, and the faculty subscribe to and sign the statement of doctrine which underlies our purpose.").

255. Letter from Harry M. Singleton, Assistant Sec'y, Office for Civil Rights, U.S. Dep't of Educ., to Joe L. Wall, President, Colo. Christian Coll. 1 (Oct. 25, 1985), http://www2.ed.gov/about/offices/list/ocr/docs/t9-rel-exempt/colorado-christian-college-response10251985.pdf. 
as a "religious and educational" institution as further evidence. ${ }^{256}$ Although its statement did not use the magic word "control," OCR found Biola University's facts "adequately establishe[d]" the requisite control. ${ }^{257}$ Even where an educational institution incorrectly named the controlling religious organization — such as Kenrick Seminary's statement that it was controlled by the Roman Catholic Church rather than the Archdiocese of St. Louis ${ }^{258}$ - OCR did not correct the error, but found sufficient control anyway for religious exemption to Title IX. ${ }^{259}$ Whatever the facts, OCR always found control adequate for exemption.

\section{ii. First Amendment Challenge and Compromise}

The smooth application of the February 1985 Policy Memorandum encountered a hurdle when certain rabbinic institutions refused to provide additional information regarding conflicting religious tenets beyond the ultra-minimalist statement originally submitted to OCR in the 1970s. These were among the same institutions that had described themselves as "controlled, conducted and operated by the Orthodox Jewish religion." 260 The initial form letter the institutions submitted identified by section number, but not substance, thirteen specific regulatory sections that "conflict with specific tenets of the Orthodox Jewish religion," but said no more. ${ }^{261}$ When OCR pressed for additional information about the relevant religious principles, more specificity regarding the conflict, even a sense of what the conflict was about, the

256. Letter from Clyde Cook, President, Biola Univ., to John E. Palomino, Acting Reg'l Dir., Region IX, Office for Civil Rights, U.S. Dep't of Educ. 1 (July 30, 1985), http://www2.ed.gov/about/offices/list/ocr/docs/t9-rel-exempt/biola-university-request-07301985.pdf.

257. Letter from Harry M. Singleton, Assistant Sec'y, Office for Civil Rights, U.S. Dep't of Educ., to Clyde Cook, President, Biola Univ. 1 (Sept. 3, 1985), http://www2.ed.gov/about/offices/list/ocr/docs/t9-rel-exempt/biola-university-response09031985.pdf.

258. See Letter from A. L. Trapp, President, Kenrick Seminary, to Waite H. Madison, Jr., Acting Dir., Div. of Postsecondary Educ., Dep't of Health, Educ., \& Welfare (Apr. 11, 1979), http://www2.ed.gov/about/offices/list/ocr/docs/t9-rel-exempt/kenrick-seminary-request04111979.pdf.

259. See Letter from Harry M. Singleton, Assistant Sec'y, Office for Civil Rights, U.S. Dep't of Educ., to James A. Fischer, President, Kenrick Seminary 1 (Aug. 1, 1985), http://www2.ed.gov/about/offices/list/ocr/docs/t9-rel-exempt/kenrick-seminary-response08011985.pdf.

260. See supra Section IV.E.2.a.i.a).

261. See, e.g., Letter from Office of the Dean, Rabbinical Coll. Beth Shraga, to Dir., Office for Civil Rights, Dep't of Health, Educ., \& Welfare (May 3, 1977), http://www2.ed.gov/about/offices/list/ocr/docs/t9-rel-exempt/rabbinical-college-beth-shraga-request05031977.pdf. 
rabbinic institutions refused. ${ }^{262}$ They claimed that requiring them to provide a statement of religious belief ran afoul of the First Amendment. ${ }^{263}$ The position the rabbinic institutions took in 1985 was consistent with the inherent exemption they had asserted in their original statements, statements that they submitted "to establish the inapplicability of the regulations to [their] institution[s]. ${ }^{, 264}$ For nearly a decade, that statement of inherent exemption sufficed.

Rather than insisting on a statement of religious tenets, as the formal regulations actually required, OCR quickly implemented a work around to avoid, in OCR's own words, "possible constitutional entanglements." ${ }^{265}$ Rabbi Morris Sherer, President of Agudath Israel of America, an Orthodox Jewish communal organization, proposed that educational institutions describe their practices rather than their religious tenets. $^{266}$ OCR agreed. ${ }^{267}$ Where the exemption claim identified the controlling religious organization and the relevant sections of the regulation, OCR would accept a statement of "institution practices, as based on religious tenets" as sufficient for religious exemption. ${ }^{268}$ OCR's draft form letter attached to the February 1985 memorandum already used the phrase "practice as ... based on religious tenet" as it instructed regional offices to summarize information from the claimant educational institution. ${ }^{269}$ Actual exemption disposition letters that OCR

262. Memorandum re Title IX Religious Exemptions from Harry M. Singleton, Assistant Sec'y, Office for Civil Rights, U.S. Dep't of Educ., to Reg'l Dirs., Regions I-X, Office for Civil Rights, U.S. Dep't of Educ. (Aug. 2, 1985) [hereinafter Singleton Memorandum dated August 2, 1985], http://www2.ed.gov/about/offices/list/ocr/docs/singleton-memo-19850802.pdf; Letter from Harry M. Singleton, Assistant Sec'y, Office for Civil Rights, U.S. Dep't of Educ., to Rabbi Morris Sherer, President, Agudath Isr. of Am. (July 19, 1985), in Singleton Memorandum dated August 2, 1985, supra.

263. Singleton Memorandum dated August 2, 1985, supra note 262; Letter from Harry M. Singleton, Assistant Sec'y, Office for Civil Rights, U.S. Dep't of Educ., to Rabbi Morris Sherer, President, Agudath Isr. of Am. (July 19, 1985), in Singleton Memorandum dated August 2, 1985, supra note 262.

264. See, e.g., Letter from Office of the Dean, Rabbinical Coll. Beth Shraga, to Dir., Office for Civil Rights, Dep't of Health, Educ., \& Welfare (May 3, 1977), http://www2.ed.gov/about/offices/list/ocr/docs/t9-rel-exempt/rabbinical-college-beth-shraga-request05031977.pdf.

265. Singleton Memorandum dated August 2, 1985, supra note 262.

266. See Letter from Harry M. Singleton, Assistant Sec'y, Office for Civil Rights, U.S. Dep't of Educ., to Rabbi Morris Sherer, President, Agudath Isr. of Am. (July 19, 1985), in Singleton Memorandum dated August 2, 1985, supra note 262.

267. Singleton Memorandum dated August 2, 1985, supra note 262.

268. Id.

269. February 1985 Policy Memorandum, supra note 136, Tab C, Form Letter Two ("In your letter you indicate that [summarize any practices that faculty and students must be aware of and follow]. Thus, the institution practices the following: 1. [Briefly describe practice as its [sic] based 
had sent to other educational institutions also used the practice-as-basedon-tenets language. ${ }^{270}$

The Agudath compromise was straightforward, but presented the first real challenge to OCR's authority and policies since BYU in 1975. The arguments in opposition were also similar to those BYU had made: the Constitution forbade the sort of religious entanglement that OCR review of religious exemption claims entailed. The rabbinic institutions went further than BYU regarding the constitutional impermissibility of even requiring a statement of religious principles, whether or not review itself occurred. Neither Agudath Israel of America nor OCR cited legal support for the action/belief division they implemented, ${ }^{271}$ but the distinction was firmly grounded in law as the U.S. Supreme Court first articulated in Reynolds $v$. United States in $1878 .^{272}$

OCR promptly communicated the Agudath compromise to the regional offices. ${ }^{273}$ The regional offices, in turn, were to write to "Jewish organizations and other institutions that refuse to provide religious tenets" to inform them of the option of describing their institutional practices instead. ${ }^{274}$ At least twenty-five rabbinic institutions received exemptions based on their descriptions of institution practices rather than religious tenets themselves. ${ }^{275}$ Typically, the institutions stated "our religious tenets require us to admit only male students and to hire only male faculty."276 Explicitly implementing an action/belief distinction

on religious tenet.].”).

270. See, e.g., Letter from Harry M. Singleton, Assistant Sec'y, Office for Civil Rights, U.S. Dep't of Educ., to Marian William, President, Immaculata Coll. (June 18, 1985), http://www2.ed.gov/about/offices/list/ocr/docs/t9-rel-exempt/immaculata-college-response-

06181985.pdf ("We have recently reviewed the request filed by former President Sister Marie Antoine ... in which she described certain policies practiced at Immaculata College as consistent with the tenets of the religious organization that controls the institution.").

271. See February 1985 Policy Memorandum, supra note 136; Letter from Harry M. Singleton, Assistant Sec'y, Office for Civil Rights, U.S. Dep't of Educ., to Rabbi Morris Sherer, President, Agudath Isr. of Am. (July 19, 1985), in Singleton Memorandum dated August 2, 1985, supra note 262.

272. 98 U.S. 145 (1878) (holding that a religious belief in polygamy did not preclude criminal conviction for acting on that belief).

273. Singleton Memorandum dated August 2, 1985, supra note 262.

274. Id.

275. See Title IX Religious Exemption Database, supra note 12; see, e.g., Letter from Harry M. Singleton, Assistant Sec'y, Office for Civil Rights, U.S. Dep't of Educ., to Rabbi E. Joshua Geldzahler, Dean, Yeshiva \& Mesivta Ohr Yisroel (Sept. 23, 1985), http://www2.ed.gov/about/offices/list/ocr/docs/t9-rel-exempt/yeshiva-and-mesivta-ohr-yisroelresponse-09231985.pdf.

276. See, e.g., Letter from Rabbi Murray Yarmark, Adm'r, Beth Medrash Emek Halacha, to Stanley Seidenfeld, Acting Reg'1 Dir., Region II, Office for Civil Rights, U.S. Dep't of Educ. (Sept. 11, 1985), http://www2.ed.gov/about/offices/list/ocr/docs/t9-rel-exempt/beth-medrash-emek- 
allowed OCR and educational institutions to avoid litigation over the constitutional parameters of religious exemption to Title IX.

\section{b. Claims Closed, but Not Denied}

As part of the Religious Exemption Project, OCR administratively closed seventy-nine claim files. ${ }^{277}$ Forty-five percent of the file closures were entirely straightforward because the institutions no longer existed (11), 34 C.F.R. $\S 106.15$ allowed the single-sex private K-12 or undergraduate education the institutions offered (21), or the institutions did not receive federal financial aid and thus were not constrained by Title IX (3). ${ }^{278}$ Fifteen institutions (20\%) failed to respond to OCR's request for more information. ${ }^{279}$ Another twenty-eight (35\%) withdrew their claims, the most theoretically interesting on principled grounds of inherent exemption. ${ }^{280}$

Within the group of educational institutions that withdrew their requests, eight institutions associated with the Lutheran Church-Missouri Synod did so to assert their authority vis-à-vis the Department of Education, to assert the authority of the Title IX statute over its implementing regulations. ${ }^{281}$ Their withdrawal letters cited the advice of legal counsel or relied on the statutory argument legal counsel provided. $^{282}$ The Synod took the position that Title IX itself exempted the educational institutions: the educational institutions did not need tonor should they-request or claim an exemption as the exemption already existed independent of the regulatory procedure set forth in 34 C.F.R. $\S 106.12$ (b) for claiming it. ${ }^{283}$ The Synod's stance mirrored

halacha-request-09191985.pdf.

277. See Title IX Religious Exemption Database, supra note 12; see also November 1985 REP Completion Memorandum, supra note 136, Tab A.

278. Title IX Religious Exemption Database, supra note 12.

279. Id.

280. Id. A handful of institutions withdrew their requests because they did not discriminate based on sex, had become co-educational or otherwise changed their programs, or saw no present need for an exemption. For the remainder, the documentary record shows no specific reason why they withdrew their claims in 1985, although a number went on to make additional claims in future years.

281. Id.

282. See, e.g., Letter from James H. Pragman, Interim President, Concordia Coll. in Seward, to Jesse L. High, Reg'l Dir., Region VII, Office for Civil Rights, U.S. Dep't of Educ. (July 12, 1985), http://www2.ed.gov/about/offices/list/ocr/docs/t9-rel-exempt/concordia-college-request07111985.pdf.

283. Id. Six institutions clearly withdrew their claims on the advice of counsel. Two other institutions associated with the Lutheran Church-Missouri Synod, also withdrew their requests at the same time, although the documentary evidence does not explicitly say they were doing so on the 
Brigham Young University's position in 1975 and as well the one rabbinic institutions asserted in 1977 in their minimalist claim letters: religious exemption to Title IX existed as a statutory and constitutional matter, irrespective of the regulatory claim procedure in 34 C.F.R. $\S$ 106.12(b) or OCR's review of a claim.

The sixteen institutions that did not respond presented a variety of circumstances as well. $^{284}$ Three were rabbinic institutions that failed to respond to letters informing them they could describe practices rather than beliefs. ${ }^{285}$ The two Catholic institutions whose files were closed failed to identify the specific sections of the regulations with which their religious tenets conflicted. ${ }^{286}$ Other similar Catholic institutions had made the same claims and identified specific sections for exemption, but consistent with the February 1985 memorandum, OCR did not read into these two claims, information from other institutions or its own knowledge of the regulations. At least three institutions did not respond to requests for additional information within the set time frame but, like some institutions that had withdrawn claims, later made a new request. ${ }^{287}$ Neither withdrawing a claim nor failure to respond to OCR requests for information precluded an educational institution from claiming or otherwise asserting a religious exemption in the future.

\section{c. No Demonstrated Conflict-Neither Denial nor Recognition}

In seven instances as part of the Religious Exemption Project, OCR told an educational institution that, with respect to a particular regulatory section, its exemption claim letter did not demonstrate a conflict between that section and the institution's stated religious tenet or practice. ${ }^{288}$

advice of counsel. The failure of a ninth institution to respond to OCR's request for additional information in 1985 may have been a passive means of withdrawing the exemption claim as the Synod's counsel advised. See Title IX Religious Exemption Database, supra note 12.

284. All factual assertions in this paragraph are based on the Title IX Religious Exemption Database, supra note 12.

285. See id.

286. See id.

287. See id.

288. Baylor University (Texas); Campbell University (North Carolina); Crowley's Ridge College (Arkansas); Los Angeles Baptist College (California); Louisiana College (Louisiana); Southern Baptist College (Arkansas); Wheaton College (Illinois). See Title IX Religious Exemption Database, supra note 12. In addition to the seven instances during the Religious Exemption Project, OCR found no conflict between the stated religious principles and specific regulatory section two other times, once in 1988 with respect to Emmaus Bible College (Iowa) and once in 1989 regarding Multnomah University (Multnomah School of the Bible, Multnomah Bible College) (Oregon). See $i d$. Thus, over the forty years since the regulations became effective, OCR has found no conflict fewer than ten times. 
Without an avowed conflict, OCR could have denied the claimed exemption for the particular regulatory section at issue, but it did not. Rather, after finding no conflict, OCR always left open the opportunity for the institution to provide a more definitive description of religious practices that conflicted with the specific section. OCR never said "no." Moreover, in each instance where it found no stated conflict with a specific regulatory section, OCR also recognized other exemption claims the institution had made in the same request letter.

When Baylor University claimed exemption from Title IX in 1976, it cited Southern Baptist religious tenets regarding pre-marital chastity as inconsistent with six different regulatory sections to the degree that the sections required the University to "treat the pregnancy, childbirth, false pregnancy or termination of pregnancy of an unmarried woman as a mere temporary disability," whether she was a student, faculty member, or other employee. ${ }^{289}$ Likewise, the University set forth religious tenets regarding a male-only ordained ministry - and the related scholarship, coursework, clubs, programs, and employment limitations that imposed on women - as conflicting with ten additional regulatory sections, including $\S 106.11$, the section that made Title IX generally applicable. ${ }^{290}$ In its response, OCR recognized Baylor's exemption claim to every regulatory section it had sought, except $\S 106.11 .^{291}$ With respect to $\S 106.11$, Baylor's claim letter "did not demonstrate that the institution's practices conflict with all sections of the Title IX regulation. ${ }^{292}$ Where Baylor set forth specific religious tenets or practices that conflicted with specific regulatory sections, OCR recognized the exemption. It did not, however, recognize a blanket exemption from all of Title IX. ${ }^{293}$

\footnotetext{
289. Letter from Abner V. McCall, President, Baylor Univ., to Dir., Office for Civil Rights, Dep't of Health, Educ., \& Welfare 1 (Jan. 12, 1976), http://www2.ed.gov/about/offices/list/ocr/docs/t9-rel-exempt/baylor-university-request01121976.pdf.

290. Id. at $1-2$.

291. Letter from Harry M. Singleton, Assistant Sec'y, Office for Civil Rights, U.S. Dep't of Educ., to Herbert H. Reynolds, President, Baylor Univ. 1-2 (Sept. 26, 1985), http://www2.ed.gov/about/offices/list/ocr/docs/t9-rel-exempt/baylor-university-response09261985.pdf.

292. Id. at 2 (emphasis added).

293. Southern Baptist College submitted a claim very similar to Baylor's and OCR responded as it had done to Baylor, recognizing exemptions for specific regulatory sections but not the general applicability of Title IX as set forth in $\S 106.11$. Letter from Harry M. Singleton, Assistant Sec'y, Office for Civil Rights, U.S. Dep't of Educ., to D. Jack Nicholas, President, Southern Baptist Coll. (Sept. 26, 1985), http://www2.ed.gov/about/offices/list/ocr/docs/t9-rel-exempt/southern-baptistcollege-response-09261985.pdf.
} 
A small handful of institutions claimed exemption for sex-segregated practices that Title IX actually allowed rather than prohibited, most around single-sex housing. In such cases, OCR noted the lack of conflict with the regulations and cited the permissive section, $\S 106.32$ that allowed single-sex housing and $\S 106.14$ that allowed sex-selective membership practices for certain social and service organizations. ${ }^{294}$ When it did not see a conflict between the religious practices the educational institution described and the regulatory sections, OCR allowed that the institution still might and directed the institution to "submit clarification of this request to the regional office" if it perceived a conflict. ${ }^{295}$ It does not appear, however, that any institution submitted clarifying requests after OCR found no conflict with a specific regulatory section.

OCR also at times clarified the applicable regulatory sections or noted that the particular practice was better exempted through a different section rather than the one requested. For example, Crowley's Ridge College requested an exemption under $\S 106.32$ (housing) to allow it to give preference based on sex in hiring dormitory supervisors. ${ }^{296}$ OCR found $\S 106.32$ inapplicable - it allowed single-sex housing but said nothing about staff hiring - but identified three exemptions to other sections regarding employment, hiring, and job classification/structure, exemptions it had already recognized, as allowing the College's sexsegregated dormitory supervisor staffing practices. ${ }^{297}$

294. See, e.g., Letter from Harry M. Singleton, Assistant Sec'y, Office for Civil Rights, U.S. Dep't of Educ., to Norman Adrian Wiggins, President, Campbell Univ. 2 (Sept. 3, 1985), http://www2.ed.gov/about/offices/list/ocr/docs/t9-rel-exempt/campbell-university-response09031985.pdf; Letter from Harry M. Singleton, Assistant Sec'y, Office for Civil Rights, U.S. Dep't of Educ., to Robert L. Lynn, President, La. Coll. 2 (Sept. 20, 1985), http://www2.ed.gov/about/offices/list/ocr/docs/t9-rel-exempt/louisiana-college-response09201985.pdf.

295. See, e.g., Letter from Harry M. Singleton, Assistant Sec'y, Office for Civil Rights, U.S. Dep't of Educ., to Robert L. Lynn, President, La. Coll. 2 (Sept. 20, 1985), http://www2.ed.gov/about/offices/list/ocr/docs/t9-rel-exempt/louisiana-college-response-

09201985.pdf. Louisiana College claimed exemption to employment, hiring, and job classification/structure sections, but specifically related religious tenets only to students' churchrelated vocational training and scholarship assistance. $I d$. OCR recognized an exemption for the student sections but not the employment sections. Id. at 1-2.

296. Letter from Emmett Smith, Chancellor, Crowley's Ridge Coll., to David S. Tatel, Dir., Office for Civil Rights, Dep't of Health, Educ., \& Welfare 2 (Aug. 5, 1977), http://www2.ed.gov/about/offices/list/ocr/docs/t9-rel-exempt/crowleys-ridge-college-request08051977.pdf.

297. Letter from Harry M. Singleton, Assistant Sec'y, Office for Civil Rights, U.S. Dep't of Educ., to Alan Carter, Exec. Vice President, Crowley's Ridge Coll. 2 (Sept. 26, 1985), http://www2.ed.gov/about/offices/list/ocr/docs/t9-rel-exempt/crowleys-ridge-college-response09261985.pdf. 
Apart from the Religious Exemption Project, in 1989 OCR recognized an exemption for Multnomah University for "§ 106.36 (counseling and use of appraisal and counseling materials)" where the University counseled women against degrees in theology and divinity because "most churches do not ordain women as ministers." 298 OCR did not, however, find a conflict with $\S 106.34$ (access to course offerings) because Multnomah University's Vice President had stated that "all educational programs are open to men and women," despite the counsel women would receive regarding their course and degree selection. ${ }^{299}$ Likewise, in 1988, Emmaus Bible College claimed an exemption regarding its student employment practices as it did not "fight or question" outside employers' "exercise [of] gender-based preferences." 300 Emmaus Bible College justified its deference to employers as promoting "religious as well as social good will between the college and the local community." 301 OCR simply noted that Emmaus Bible College had not identified a conflict between a religious tenet or practice and the regulatory section. ${ }^{302}$

Throughout the Religious Exemption Project and after, OCR invited each of the educational institutions to clarify the conflict between religious tenets and regulatory sections, if it disagreed. OCR explicitly left open the possibility that it misread or erroneously interpreted or misunderstood the educational institution's exemption claim, that its decision was something other than final. OCR did not say "no."

298. Letter from William L. Smith, Acting Assistant Sec'y, Office for Civil Rights, U.S. Dep't of Educ., to Joseph C. Aldrich, President, Multnomah Sch. of the Bible 2 (May 31, 1989), http://www2.ed.gov/about/offices/list/ocr/docs/t9-rel-exempt/multnomah-school-of-the-bible-

response-05311989.pdf. As of 2008, Multnomah University is the successor institution to Multnomah College of the Bible. History, MultNOMAH U., www.multnomah.edu/about/history (last visited Oct. 10, 2016).

299. Letter from William L. Smith, Acting Assistant Sec'y, Office for Civil Rights, U.S. Dep't of Educ., to Joseph C. Aldrich, President, Multnomah Sch. of the Bible 2 (May 31, 1989), http://www2.ed.gov/about/offices/list/ocr/docs/t9-rel-exempt/multnomah-school-of-the-bibleresponse-05311989.pdf.

300. Letter from Daniel H. Smith, President, Emmaus Bible Coll., to Assistant Sec'y, Office for Civil Rights, U.S. Dep't of Educ. 4 (Aug. 25, 1988), http://www2.ed.gov/about/offices/list/ocr/docs/t9-rel-exempt/emmaus-bible-college-request08251988.pdf.

301. Id.

302. Letter from LeGree S. Daniels, Assistant Sec'y, Office for Civil Rights, U.S. Dep't of Educ., to Daniel H. Smith, President, Emmaus Bible Coll. 2 (Mar. 21, 1989), http://www2.ed.gov/about/offices/list/ocr/docs/t9-rel-exempt/emmaus-bible-college-response03211989.pdf. 


\section{F. Claims and Complaints Immediately Post-Religious Exemption Project}

Following on the completion of the Religious Exemption Project in November 1985, OCR quickly encountered complaints against some of the institutions for which it had just formally recognized religious exemptions. Students filed formal complaints against at least three institutions - the Seventh Day Adventist Oakwood College, Catholic Elms College, and LDS Brigham Young University-Idaho-regarding student health insurance plans and coverage for pregnancy and related conditions. ${ }^{303}$ These complaints and OCR's resolution of them, as well as independent exemption claims by two Catholic institutions, Loyola University-New Orleans and Stonehill College, ${ }^{304}$ portended a wave of religious exemption claims regarding coverage for abortion and out-ofwedlock pregnancy in student health insurance plans. ${ }^{305}$ Where OCR determined it had jurisdiction, as it did for the complaints against Oakwood College and Elms College, it responded quickly. Where it did not find jurisdiction, as in the complaint against BYU-Idaho, the exemption claim lingered. ${ }^{306}$

OCR documented a religious exemption for Oakwood College on September 3, 1985, along with the exemption claims of at least ten other educational institutions. ${ }^{307}$ Although OCR recognized Oakwood's exemption claim as part of the Religious Exemption Project, Oakwood's

\footnotetext{
303. See Memorandum re Policy Guidance Request for Oakwood College, Alabama, OCR Complaint No. 04-85-2078 from Alicia Coro, Acting Assistant Sec'y, Office for Civil Rights, U.S. Dep't of Educ., to W. Lamar Clements, Acting Reg'l Dir., Region IV, Office for Civil Rights, U.S. Dep't of Educ. (Feb. 18, 1985) [hereinafter Memorandum re Oakwood College] (on file with author); Letter from Alicia Coro, Acting Assistant Sec'y, Office for Civil Rights, U.S. Dep't of Educ., to Sister Mary Dooley, President, Elms Coll. (Oct. 1, 1986), http://www2.ed.gov/about/offices/list/ocr/docs/t9-rel-exempt/elms-college-response-10011986.pdf; Letter from LeGree S. Daniels, Assistant Sec'y, Office for Civil Rights, U.S. Dep't of Educ., to Joe J. Christensen, President, Ricks Coll. (June 22, 1988), http://www2.ed.gov/about/offices/list/ocr/docs/t9-rel-exempt/ricks-college-response-06221988.pdf.

304. Letter from Alicia Coro, Acting Assistant Sec'y, Office for Civil Rights, U.S. Dep’t of Educ., to James C. Carter, President, Loyola Univ. (May 7, 1986), http://www2.ed.gov/about/offices/list/ocr/docs/t9-rel-exempt/loyola-university-response-

05071986.pdf; Letter from Alicia Coro, Acting Assistant Sec'y, Office for Civil Rights, U.S. Dep't of Educ., to Bartley MacPhaidin, President, Stonehill Coll. (May 15, 1986), http://www2.ed.gov/about/offices/list/ocr/docs/t9-rel-exempt/stonehill-college-response05151986.pdf.

305. Ten educational institutions claimed religious exemption in late 1985 and 1986. Title IX Religious Exemption Database, supra note 12. OCR promptly resolved nine of them, but left an exemption claim by BYU-Idaho unresolved until 1988. Id.

306. See infra Section IV.G.2.a.

307. November 1985 REP Completion Memorandum, supra note 136, Tab C, at 2.
} 
specific claim to discriminate based on marital/parental status had been pending before OCR only for a month, since August $1985 .^{308}$ The Regional Civil Rights Director for Region IV, the region including Alabama, sought guidance from the Assistant Secretary for Civil Rights on how to treat the complaint against Oakwood, given the religious exemption Oakwood had received. ${ }^{309}$ After discussing certain jurisdictional issues, ${ }^{310}$ OCR analyzed Oakwood College's religious exemption, noting that the scope of exemption did not extend to "practices that do not conflict with [the institution's] religious tenets." 311 Thus, Oakwood College could discriminate against unmarried, pregnant women in its student health insurance plan by refusing to treat pregnancy as it did other temporary disabilities, but it could not do the same to married, pregnant women because "[t]he College has made no statement or suggestion that the presence of students or employees who are married and pregnant conflicts with any tenets of the religious organization controlling the institution." 312 The policy guidance reinforced the statutory limitation on religious exemptions. An educational institution could be exempt, but only so far as religious principles conflicted with regulatory requirements. If there was no religious conflict, there was no exemption.

An OCR-initiated Title IX compliance review of student health insurance plans in Region IV, the region including both Oakwood College in Alabama and Loyola University in Louisiana, motivated Loyola University-New Orleans to seek religious exemption in April $1986 .^{313}$ Loyola claimed exemption to Title IX regulations regarding health and insurance benefits and services for students as well as the marital or parental status of applicants, students, and employees, although its exemption claim letter only discussed religious tenets regarding abortion and sterilization rather than prohibitions on extra-

\footnotetext{
308. Memorandum re Oakwood College, supra note 303.

309. See id. At the time, both positions were filled by interim personnel, Alicia Coro as Acting Assistant Secretary for Civil Rights, and W. Lamar Clements as Acting Regional Civil Rights Director. Id.

310. The jurisdictional issues were complex and related to the Supreme Court's decision in Grove City Coll. v. Bell, 465 U.S. 555 (1984), which the Civil Rights Restoration Act of 1987, Pub. L. No. 100-259, 102 Stat. 28 (1988), overturned in March 1988.

311. Memorandum re Oakwood College, supra note 303, at 1.

312. Id. at $1-2$.

313. Letter from James C. Carter, President, Loyola Univ., to Alicia Coro, Acting Assistant Sec'y, Office for Civil Rights, U.S. Dep't of Educ. 1 (Apr. 8, 1986), http://www2.ed.gov/about/offices/list/ocr/docs/t9-rel-exempt/loyola-university-request04081986.pdf.
} 
marital sex. ${ }^{314}$ The University said it was willing to modify its student health insurance plan to treat pregnancy and related conditions the same as other temporary disabilities but it refused to provide coverage and counseling regarding abortion because the "long-established teaching of the Catholic Church through its various Councils, Papal Encyclicals and other teaching authorities" defined the "intentional termination of pregnancy through means of abortion as the wrongful taking of human life contrary to the natural and moral law of the Church., 315 Loyola claimed exemption from any regulations that would limit its ability to discipline students or fire employees based on "conduct related to termination of pregnancy by abortion." 316 Less than a month later, OCR recognized Loyola's exemption in a letter that followed exactly the format of the Religious Exemption Project recognition letters. ${ }^{317}$ Thirty years later in 2016, Loyola wrote to OCR to disavow this claim for exemption because it no longer offered student health plans. ${ }^{318}$

In 1985, Elms College had withdrawn its claim for religious exemption during the Religious Exemption Project, ${ }^{319}$ but reinstituted that claim in 1986 after a complaint regarding its student health insurance plan. ${ }^{320}$ Elms College asked for and received exemption from a narrower set of regulations than had Loyola University, just marital or parental status of students and employees, to the extent the sections required services or benefits related to the termination of pregnancy. ${ }^{321}$ The narrowness of Elms College's claimed exemption may have been related to the context in which the 1986 claims arose and the College's withdrawal of a previous claim in October 1985. While the documentary record does not explain the 1985 withdrawal, both the withdrawal and

\footnotetext{
314. Id. at 2 .

315. Id. at $1-2$

316. Id. at 2 .

317. Letter from Alicia Coro, Acting Assistant Sec'y, Office for Civil Rights, U.S. Dep't of Educ., to James C. Carter, President, Loyola Univ. (May 7, 1986), http://www2.ed.gov/about/offices/list/ocr/docs/t9-rel-exempt/loyola-university-response05071986.pdf.

318. Letter from Kevin Wm. Wildes, President, Loyola Univ. New Orleans, to Catherine E. Lhamon, Assistant Sec'y, Office for Civil Rights, U.S. Dep't of Educ. (May 19, 2016), http://www2.ed.gov/about/offices/list/ocr/docs/t9-rel-exempt/loyola-university-request05192016.pdf.

319. November 1985 REP Completion Memorandum, supra note 136, Tab D, at 3.

320. Letter from Alicia Coro, Acting Assistant Sec'y, Office for Civil Rights, U.S. Dep't of Educ., to Sister Mary Dooley, President, Elms Coll. 1 (Oct. 1, 1986), http://www2.ed.gov/about/offices/list/ocr/docs/t9-rel-exempt/elms-college-response-10011986.pdf.

321. Id.; Letter from Sister Mary Dooley, President, Elms Coll., to Alicia Coro, Acting Assistant Sec'y, Office for Civil Rights, U.S. Dep't of Educ. (Sept. 2, 1986), http://www2.ed.gov/about/offices/list/ocr/docs/t9-rel-exempt/elms-college-request-09021986.pdf.
} 
the very narrow 1986 exemption claim may indicate a position that religious exemption existed independent of the regulatory procedures for claiming it and needed to be formally documented only in situations of actual conflict. The actual conflict arose when a student filed a student health insurance policy complaint with the Boston Regional Office for Civil Rights. ${ }^{322}$ Elms College had accepted a proposed settlement, except for its required coverage for abortion "a practice that would violate the religious tenets followed by Elms College," and the Roman Catholic Church. ${ }^{323}$ A documented religious exemption to coverage for abortion resolved in Elms College's favor that portion of the student's complaint against it.

When Stonehill College, a small Catholic institution in the northeast like Elms College, claimed an exemption to the student health insurance coverage sections of the Title IX regulations, it argued that "any statute or regulation mandating insurance coverage for the health care related to pregnancies out of wedlock, or abortions regardless of marital status, is obviously inconsistent with the religious tenets" of its controlling organization, the Congregation of Holy Cross, a Catholic religious order. $^{324}$ OCR accepted the "obviously inconsistent" assertion without seeking more information or a more specific sourcing of Catholic religious tenets to official documents like Loyola University and Elms College had provided in their exemption claims. ${ }^{325}$

\section{G. The Civil Rights Restoration Act of 1987}

\section{Restoring an Expansive Interpretation}

The administrative agency charged with enforcing Title IX - first the Department of Health, Education, and Welfare and then, beginning in 1980, the Department of Education-long interpreted Title IX's nondiscrimination provisions as it understood congressional intent to be in

322. Letter from Alicia Coro, Acting Assistant Sec'y, Office for Civil Rights, U.S. Dep't of Educ., to Sister Mary Dooley, President, Elms Coll. 1 (Oct. 1, 1986), http://www2.ed.gov/about/offices/list/ocr/docs/t9-rel-exempt/elms-college-response-10011986.pdf.

323. Id.

324. Letter from Bartley MacPhaidin, President, Stonehill Coll., to Patricia A. Healy, Assistant Sec'y, Office for Civil Rights, U.S. Dep't of Educ. (Apr. 17, 1986), http://www2.ed.gov/about/offices/list/ocr/docs/t9-rel-exempt/stonehill-college-request04171986.pdf.

325. Letter from Alicia Coro, Acting Assistant Sec'y, Office for Civil Rights, U.S. Dep't of Educ., to Bartley MacPhaidin, President, Stonehill Coll. (May 15, 1986), http://www2.ed.gov/about/offices/list/ocr/docs/t9-rel-exempt/stonehill-college-response05151986.pdf. 
passing the law: Title IX applied to the entire educational institution where any program or activity at the university received federal financial assistance. ${ }^{326}$ The Title IX regulations defined the term "recipient" as an entity that received federal financial assistance, whether directly or indirectly, and that "operates an education program or activity that receives or benefits from such assistance." 327 Both the regulatory language regarding indirect receipt of federal financial assistance (i.e., through federal financial aid assistance to students) and "benefits from" effectuated that expansive interpretation.

In 1984 in Grove City College v. Bell, however, the U.S. Supreme Court rejected the expansive interpretation of Title IX as applicable to all portions of an educational institution where any part of it received federal financial assistance or benefited therefrom. ${ }^{328}$ Rather, the Court interpreted narrowly the "program or activity" language of Title IX such that its non-discrimination provisions applied only to the specific program or activity receiving federal funds, not the entire university. ${ }^{329}$ For Grove City College, this meant that only its student financial aid program-not admissions, not athletics, not employment, not any other program or activity at the university - was subject to Title IX because the only federal funds the College received were through federal financial aid given to students. ${ }^{330}$ The Court's strict interpretation constructed Title IX as BYU and other educational institutions had previously urged to severely limit the statute's reach. ${ }^{331}$ In March 1988, after a failed attempt in 1984 and over President Ronald Reagan's veto, ${ }^{332}$ Congress enacted the Civil Rights Restoration Act of 1987 (CRRA) to derogate Grove City College and, in the bill's words, "restore the prior consistent and long-standing executive branch interpretation and broad, institutionwide application" of Title IX. ${ }^{333}$

326. See Conforming Amendments to the Regulations Governing Nondiscrimination on the Basis of Race, Color, National Origin, Disability, Sex, and Age Under the Civil Rights Restoration Act of 1987, 65 Fed. Reg. 68050, 68050, 68052 (Nov. 13, 2000).

327. Id. (quoting Department of Health, Education, and Welfare, General Administration, 40 Fed. Reg. 24128, 24137 (June 4, 1975)).

328. 465 U.S. 555, 573-74 (1984), superseded by statute, Civil Rights Restoration Act of 1987, Pub. L. No. 100-259, 102 Stat. 28 (1988).

329. Id.

330. Id.

331. See BYU Notification, supra note 60.

332. Civil Rights Monitor, Congress Overrides the President's Veto of the Civil Rights Restoration Act, LEADERSHIP CONF. (Mar. 1988), http://www.civilrights.org/monitor/march1988/art1p1.html.

333. Civil Rights Restoration Act of 1987, Pub. L. No. 100-259, § 2, 102 Stat. 28,28 (1988) (codified at 20 U.S.C. $\$ 1687$ (2012)). 
While the CRRA returned Title IX to its previously expansive application, two attempts by Senator Orrin Hatch (R-Utah) to limit that return with respect to religious institutions failed. First, Senator Hatch proposed an amendment to the CRRA that would have maintained Grove City College's narrow interpretation for religious institutions. ${ }^{334}$ His second proposed amendment would have broadened the application of the religious exemption by changing the requirement that an educational institution be "controlled by" a religious organization to simply "closely identified" with the tenets of a religious organization. ${ }^{335}$ With the defeat of Senator Hatch's second amendment, the CRRA reiterated exactly the language of religious exemption found in the original Title IX. To claim exemption, an educational institution had to be controlled by a religious organization.

Even after defeat of Senator Hatch's two amendments, return to the expansive application of Title IX was not entirely complete. Between original passage of Title IX in 1972 and the Supreme Court's ruling in Grove City College, the Supreme Court decided Roe v. Wade in 1973. ${ }^{336}$ Of course, prior to the introduction of the CRRA, various educational institutions had sought religious exemptions regarding abortion. ${ }^{337}$ With abortion legal under certain circumstances after 1973, however, some opposition to the CRRA focused on the degree to which Title IX would then require educational institutions to fund or otherwise participate in abortions, particularly through their student health insurance plans. ${ }^{338}$ The religious exemption in Title IX covered some of the institutions that were most adamantly opposed to the CRRA, but religious exemptions were not available to all who opposed abortion. ${ }^{339}$ In January 1988, Senator John Danforth (R-Missouri) introduced an amendment that sought to make Title IX "abortion-neutral," a successful amendment that facilitated passage of the CRRA, after earlier failure in 1984 in large part

\footnotetext{
334. Civil Rights Monitor, Congress Overrides the President's Veto of the Civil Rights Restoration Act, LEADERSHIP CONF. (Mar. http://www.civilrights.org/monitor/march1988/art1p1.html.

335. Id.

336. 410 U.S. 113 (1973).

337. See, e.g., The Catholic University of America (Washington, D.C.), Mid-America Bible College (Oklahoma), Presentation College (South Dakota), Roberts Wesleyan College (New York), Stonehill College (Massachusetts), West Coast Christian College (California). See Title IX Religious Exemption Database, supra note 12.

338. See 1 William A. Kaplin \& Barbara A. Lee, The LaW of Higher Education $§$ 8.7.2 (5th ed. 2013); Margaret C. DunkLe, Women's Educ. EQuity ACt Program, Just What the Doctor Should Have Ordered: A Prescription for SEX-Fair School Health SERVices 7-8 (1989) [hereinafter DUNKLE], http://files.eric.ed.gov/fulltext/ED319142.pdf.

339. DUNKLE, supra note 338 , at 8-9.
} 
over the abortion question. ${ }^{340}$ Senator Danforth's amendment was a substantive limit on the scope of Title IX coverage. Under the "Neutrality with Respect to Abortion" amendment, nothing in Title IX was to be construed to either "require or prohibit" anyone, whether a public or a private entity or individual person "to provide or pay for any benefit or service, including the use of facilities, related to an abortion." $" 341$ At the same time, absent a religious exemption, the amendment did not allow institutions to discriminate against someone who had received or sought a legal abortion or related services. ${ }^{342}$

The CRRA resulted in a host of new religious exemption claims and a revised strategy for OCR on dealing with complaints it had closed for lack of jurisdiction, ${ }^{343}$ like the one against BYU-Idaho's student health insurance plan initially filed in $1985 .^{344}$ Of the forty-two religious exemption claims OCR received in the last nine months of 1988 after passage of the CRRA and in 1989, 69\% either claimed an explicit exemption for services related to abortion, cited the CRRA as obviating the need for an exemption, or, in the case of two educational institutions, God's Bible School College in Cincinnati and Mississippi College, did both for good measure. ${ }^{345}$ Sixteen of the forty-two claims (38\%) dealt, at least in part, with student health insurance exemptions, all to allow exclusion of unmarried women from coverage for pregnancy and related services, based on religious prohibitions on pre-marital sex. ${ }^{346}$

340. 134 Cong. ReC. S192-01 (1988), 1988 WL 1081027; see Civil Rights Monitor, Civil Rights Restoration Act Stalled By Abortion Amendment, LEADERSHIP CONF. (Oct. 1985), http://www.civilrights.org/monitor/october1985/art7p1.html; 'Grove City' Bill Delayed by Battle over Bork, in 43 CONG. QUARTERLy ALMANAC 1987, at 281, 282 (1988), http://library.cqpress.com/cqalmanac/document.php?id=cqal87-1144956.

341. 134 CONG. REC. S192-01 (1988), 1988 WL 1081027; 20 U.S.C. § 1688 (2012).

342. 134 CONG. REC. S192-01 (1988), 1988 WL 1081027; § 1688.

343. Memorandum re Interim Procedures to Implement the Civil Rights Restoration Act (Grove City Legislation) from LeGree S. Daniels, Assistant Sec'y, Office for Civil Rights, U.S. Dep't of Educ., to OCR Senior Staff, Office for Civil Rights, U.S. Dep't of Educ. (Mar. 23, 1988) [hereinafter Memorandum re Interim Procedures] (on file with author).

344. OCR closed complaint cases for lack of jurisdiction between 1984, when the Supreme Court's decision in Grove City College significantly narrowed the scope of Title IX, and March 23, 1988, the date CRRA became effective. See, e.g., Letter from LeGree S. Daniels, Assistant Sec'y, Office for Civil Rights, U.S. Dep't of Educ., to Joe J. Christensen, President, Ricks Coll. 1 (June 22, 1988), http://www2.ed.gov/about/offices/list/ocr/docs/t9-rel-exempt/ricks-college-response06221988.pdf. For a discussion of the procedural effects of the CRRA, see Memorandum re Interim Procedures, supra note 343.

345. Twenty-two institutions cited the CRRA as obviating the need for an exemption to abortion. See Title IX Religious Exemption Database, supra note 12. Seven institutions claimed a specific exemption to abortion and related services. Id.

346. See id. 
2. Finding Jurisdiction, Reopening Cases, Recognizing Exemptions: Student Health Insurance Policy Cases

By the end of 1988, OCR had received nearly 2,000 similar Title IX complaints regarding discrimination in student health insurance plans. ${ }^{347}$ The prevalence of the problem required particular attention. Twice, in June 1988 and October 1989, OCR provided policy guidance to its senior staff and regional directors regarding student health insurance policy complaints. ${ }^{348}$ In between, in September 1988, OCR mass mailed a letter to alert college and university presidents of the potential for violating Title IX if "certain student health insurance plans" did "not provide coverage for pregnancy on the same basis as coverage for other temporary disabilities." 349 In its internal policy guidance memoranda as well as its external communication with university presidents, OCR recognized the potential role of religious exemptions. ${ }^{350}$ That explicit recognition of the potential for religious exemption in the late 1980s, contrasts sharply with the limited communication about the possibility of religious exemption in the twenty-first century. ${ }^{351}$

\section{a. Concerns Regarding Abortion-June 1988 Memorandum}

OCR sought to provide guidance to its regional directors regarding the variety of ways that the Civil Rights Restoration Act affected OCR's response to complaints alleging Title IX violations in student health insurance policies. ${ }^{352}$ The abortion-neutral provision of the CRRA exempted all educational institutions, not just the religiously controlled, from providing or paying for abortions whether in student health

347. DUNKLE, supra note 338 , at $50 \mathrm{n}$ *.

348. See Memorandum re Student Health Insurance Policy Cases from Terence J. Pell, Deputy Assistant Sec'y for Policy, U.S. Dep't of Educ., to Reg'l Dirs., Regions I-X, Office for Civil Rights, U.S. Dep't of Educ. (June 8, 1988) [hereinafter June 1988 Memorandum] (on file with author); Memorandum re Title IX Religious Exemption Procedures and Instructions for Investigating Complaints at Institutions with Religious Exemptions from William L. Smith, Acting Assistant Sec'y, Office for Civil Rights, U.S. Dep't of Educ., to OCR Senior Staff, Office for Civil Rights, U.S. Dep't of Educ. (Oct. 11, 1989) [hereinafter October 1989 Memorandum], http://www2.ed.gov/about/offices/list/ocr/docs/smith-memo-19891011.pdf.

349. Letter from LeGree S. Daniels, Assistant Sec'y, Office for Civil Rights, U.S. Dep't of Educ., to College and University Presidents 1 (Sept. 21, 1988) (on file with author).

350. See id.; June 1988 Memorandum, supra note 348; October 1989 Memorandum, supra note 348

351. See infra Section V.B.

352. June 1988 Memorandum, supra note 348. 
insurance plans or otherwise. ${ }^{353}$ OCR intended to modify the Title IX regulations to accord with the new statute, but in the meantime, considered regulatory provisions regarding paying or providing for the termination of pregnancy "ultra vires," non-enforceable. ${ }^{354}$ OCR also noted that, with respect to abortion, the CRRA was neutral only regarding paying or providing for an abortion, not with respect to discrimination against students who had or were seeking to have an abortion. ${ }^{355}$ OCR emphasized the limitation by underlining the words "provide or pay" in its memorandum. ${ }^{356}$

OCR cautioned regional offices of potential interaction between the abortion neutral provision of the CRRA and religious exemptions specifically. ${ }^{357}$ If a regional office investigated a complaint at an educational institution eligible for a religious exemption, OCR should "apprise[] [the institution] of its option of claiming a religious exemption" and, if the educational institution claimed exemption, the office should "process the religious exemption before completing the investigation and issuing a letter of finding.",358

In August 1985, a student filed a complaint alleging that the health insurance plan BYU-Idaho offered to its students discriminated on the basis of sex; it did not treat pregnancy the same as other temporary disabilities. $^{359}$ OCR had acknowledged exemptions for BYU-Idaho in June 1985 as part of the Religious Exemption Project, but those exemptions did not include the University's student health plan. ${ }^{360}$ In response to the complaint, BYU-Idaho claimed additional exemptions beyond those already recognized. ${ }^{361}$ The requirement that it "treat pregnancy as any other temporary disability... would compel [the College's] direct and/or indirect approval, and support of pre-marital sex

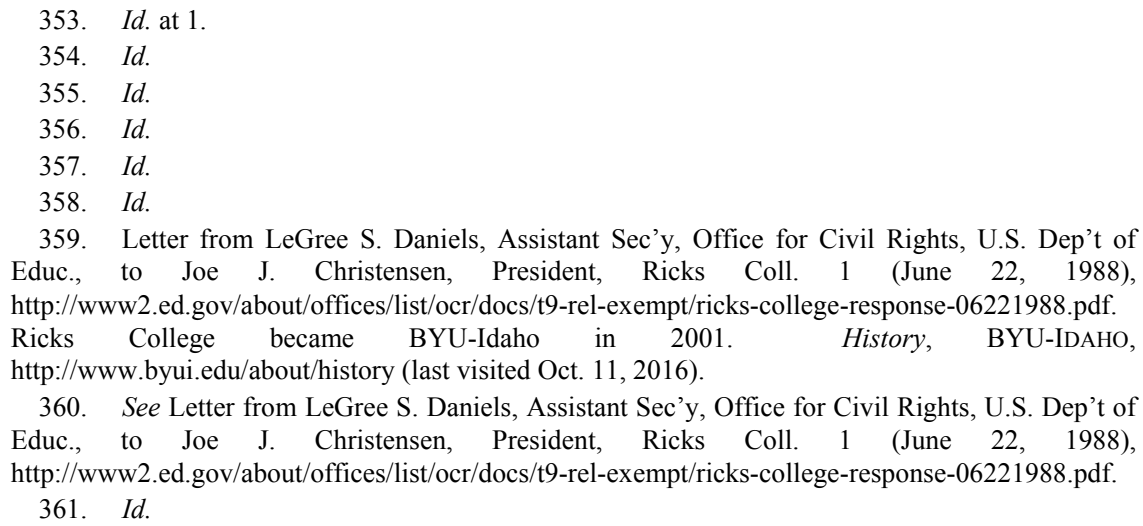


and abortion." 362 The College set forth the "fundamental doctrine" of the LDS Church as prohibiting pre-marital sex and, except in rare narrowly circumscribed situations, prohibiting participation in abortion. ${ }^{363}$ However, in 1986, OCR found it lacked jurisdiction to consider the complaint, ${ }^{364}$ given Grove City College v. Bell and OCR's policy guidance implementing Grove City College's jurisdictional limitations. ${ }^{365}$ OCR closed the complaint file against BYU-Idaho and left the exemption claim pending future jurisdiction. ${ }^{366}$

OCR found that jurisdiction in the Civil Rights Restoration Act. ${ }^{367}$ In 1988, OCR reopened the complaint against BYU-Idaho and reconsidered the institution's 1985 exemption claim. ${ }^{368}$ OCR exempted BYU-Idaho's student health insurance from treating pregnancy and related conditions as a temporary disability for unmarried women and from abortion services for all women, married or not, based on conflict between LDS religious principles and the regulatory sections. ${ }^{369}$ In doing so, OCR followed the standard format for exemption recognition letters set forth as part of the Religious Exemption Project in the February 1985 memorandum, ${ }^{370}$ but also relied on the additional guidance OCR provided in June 1988 regarding student health insurance complaints. $^{371}$

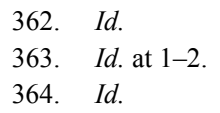

365. See Memorandum re Request for Guidance on Student Health Insurance from Harry M. Singleton, Assistant Sec'y, Office for Civil Rights, U.S. Dep't of Educ., to Jesse L. High, Reg'l Dir., Region VII, Office for Civil Rights, U.S. Dep't of Educ. (Nov. 18, 1985) (distributed to all Regional Civil Rights Directors on Nov. 22, 1985) (on file with author).

366. See Letter from LeGree S. Daniels, Assistant Sec'y, Office for Civil Rights, U.S. Dep't of Educ., to Joe J. Christensen, President, Ricks Coll. 1 (June 22, 1988), http://www2.ed.gov/about/offices/list/ocr/docs/t9-rel-exempt/ricks-college-response-06221988.pdf.

367. Immediately upon passage of the CRRA, OCR set forth detailed, technical procedures to implement the new law, including how to determine which cases closed due to lack of jurisdiction should be reopened. See Memorandum re Interim Procedures, supra note 343.

368. See Letter from LeGree S. Daniels, Assistant Sec'y, Office for Civil Rights, U.S. Dep't of Educ., to Joe J. Christensen, President, Ricks Coll. 1 (June 22, 1988), http://www2.ed.gov/about/offices/list/ocr/docs/t9-rel-exempt/ricks-college-response-06221988.pdf.

369. Id. at $1-2$.

370. See February 1985 Policy Memorandum, supra note 136, at 1-7, Tab C, Form Letter Two.

371. See June 1988 Memorandum, supra note 348. As of the June 30, 2016 update to its webpage, OCR had published the October 1989 memorandum, but not the June 1988 memorandum. See Office for Civil Rights, Religious Exemption, U.S. DEP'T EDUC. (June 30, 2016), http://www2.ed.gov/about/offices/list/ocr/frontpage/pro-students/rel-exempt-pr.html. 
b. Dear College and University Presidents—September 1988 Letter

In September 1988, OCR mass mailed a letter to alert college and university presidents of the potential for violation of Title IX where the student health insurance plans the universities offered did "not provide coverage for pregnancy on the same basis as coverage for other temporary disabilities." 372 Unlike the June 1988 memorandum, the September 1988 letter made no mention of the abortion-neutral provisions of the CRRA regarding providing or paying for abortion or the fact that the CRRA prohibited discrimination against students who had obtained or were seeking an abortion. ${ }^{373}$ It did, however, apprise institutions of the possibility of religious exemption by tracking both the substantive and procedural language of 34 C.F.R. $\S 106.12 .{ }^{374}$

c. Policy and Procedures - October 1989 Memorandum

By October 1989, OCR had recognized religious exemptions for nearly $90 \%$ of the fifty-two post-Religious Exemption Project claimants, leaving only six pending. ${ }^{375}$ Nonetheless, by memorandum dated October 11, 1989, OCR reiterated its procedures for considering the exemption claims and set forth, apparently for the first time, specific procedures for conducting complaint investigations at institutions with documented religious exemptions. ${ }^{376}$ The primary value of the October 1989 memorandum would be the procedures it identified for investigating complaints at institutions that already had documented religious exemptions rather than the policy for reviewing new exemption claims. At the same time, the procedures outlined in both the June 1988 memo and the October 1989 memo made it more difficult to determine post-hoc from the exemption documents themselves whether educational institutions made religious exemption claims in response to Title IX complaints against them or independent of such complaints.

The October 1989 memorandum maintained, indeed increased, the exceptionally deferential standard set forth in the February 1985 policy guidance memorandum that first articulated standards of review for religious exemption claims. OCR's 1989 memorandum explicitly

372. Letter from LeGree S. Daniels, Assistant Sec'y, Office for Civil Rights, U.S. Dep't of Educ., to College and University Presidents 1 (Sept. 21, 1988) (on file with author).

373. Id. at $1-2$.

374. Id. at 2 .

375. See Title IX Religious Exemption Database, supra note 12.

376. October 1989 Memorandum, supra note 348. 
recognized that religious exemptions existed independent of the regulatory procedures to document them, harkening back to the language in OCR's March 1976 letter to BYU: "The regulation does not require that a religious institution submit a written claim of exemption, nor is an institution's exempt status dependent upon its submission of a written statement." 377 Moreover, in the 1989 memorandum OCR used quote marks around the words "request" and "granting" to indicate that institutions were not actually requesting exemptions nor OCR actually granting them: "Primarily, the written claim or 'request' for exemption from an institution is a request for assurance from OCR of exemptions to certain sections of the regulation.... OCR, in 'granting' an exemption, primarily ensures that the institution has cited the correct sections of the regulation in its request." 378 In other words, OCR's role, and the extent of its authority, was simply to check regulatory section numbers. Any questions that OCR staffers had about a religious exemption claim "should be directed at clarifying the applicability of regulation sections," not questioning religious beliefs, not interpreting religious tenets, not asking about programs beyond the scope of the exemption request itself, because doing so "could create potential conflicts under the First Amendment." 379 The October 1989 memorandum moved back toward inherent exemption, but it did not change the agency discretion language OCR embodied in the standard exemption disposition letter, the primary language institutions claiming exemption would encounter.

A complaint against a religious educational institution changed the procedure OCR applied. ${ }^{380}$ If the institution had a religious exemption that OCR already documented, OCR should carefully review that letter for the parameters of the exemption to see if the complaint fell within it. ${ }^{381}$ The October 1989 memorandum did not say exactly what should happen procedurally if the exemption covered the complaint, but presumably, as with the 1986 Elms College case, ${ }^{382}$ the exemption resolved the complaint in favor of the educational institution, unless the complainant challenged the exemption itself. The publicly available record reveals no such challenge, either with respect to Elms College or any other institution claiming religious exemption.

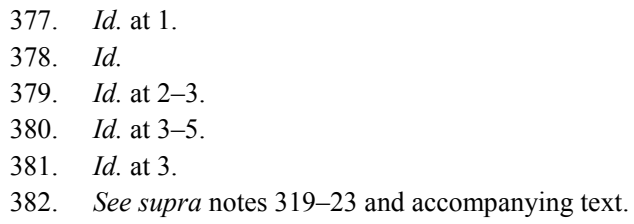


Where a complaint fell outside the scope of the documented religious exemption, OCR could investigate the religious institution. ${ }^{383}$ Indeed, the 1989 memorandum assumes that many of the complaints OCR had received regarding the treatment of pregnancy and related conditions under student health care plans would fall outside the scope of religious exemptions. ${ }^{384}$ Where educational institutions provided student health care plans, the regulations required the plans to treat pregnancy "the same... as any other temporary disability." $" 385$ The memorandum pointed out that religious educational institutions may have documented exemptions for treating married and single persons differently with respect to pregnancy because of religious tenets prohibiting extra-marital sex, but "no institution has claimed a conflict between religious tenets and the regulation regarding married pregnant students," 386 echoing its Oakwood College policy guidance communication in $1985 .{ }^{387}$ Where student health plans treated pregnancy differently from other temporary disabilities - by requiring a waiting period for coverage, by limiting hospital stays, by charging extra premiums, as many plans did-the educational institution violated Title IX regulations for married students, even if it was exempt from providing equal insurance coverage for unmarried students. ${ }^{388}$

H. Disappearance of Religious Exemption Claims, 1989-2012

Whatever it had anticipated after resolving the student health insurance plan complaints and issuing the October 1989 memorandum, OCR received no new claims to religious exemptions in the latter half of 1989, in 1990, or in 1991. ${ }^{389}$ Over the next few years, OCR received only a smattering of new exemption claims: three in 1992, two in 1993, three in 1994, none in 1995, two in 1996, all but one of these ten claims from Baptist educational institutions. ${ }^{390}$ In 1997 and 1998, three LDS

\footnotetext{
383. October 1989 Memorandum, supra note 348, at 4.

384. See id. at $4-5$.

385. 34 C.F.R. $§ 106.40$ (b)(4) (2015); see also October 1989 Memorandum, supra note 348, at 4.

386. October 1989 Memorandum, supra note 348, at 4.

387. See Memorandum re Oakwood College, supra note 303.

388. October 1989 Memorandum, supra note 348, at 4.

389. Title IX Religious Exemption Database, supra note 12.

390. Id. Lee University, which made a new claim in 1996, identified the Church of God as its controlling religious institution. Letter from Charles Paul Conn, President, Lee Coll., to Norma V. Cantú, Assistant Sec'y, Office for Civil Rights, U.S. Dep't of Educ. (Jan. 30, 1996), http://www2.ed.gov/about/offices/list/ocr/docs/t9-rel-exempt/lee-college-request-01301996.pdf. The other nine identified various Baptists religious organizations as controlling.
} 
institutions of higher education made a total of four new claims, the only claims made those years. ${ }^{391}$ Between 1999 and 2012, only two educational institutions, Trinity International University and Maranatha Baptist Bible College, made new claims to religious exemption. ${ }^{392}$ Thus, in the course of more than twenty years, from mid-1989 through 2012, OCR received only sixteen new religious exemption claims, on average fewer than one new exemption claim per year, with all but two new claims concentrated in the first ten years. ${ }^{393}$ For years on end, OCR had no new work on religious exemptions to Title IX. By 2012, it may have been easy to conclude that educational institutions' demand for religious exemption to Title IX had evaporated or at least been fulfilled through the exemptions OCR had already recognized.

\section{Claims Reemerge, 2013-Arcadia Unified School District and Transgender}

After a long hiatus, religious exemptions to Title XI re-emerged starkly. In July 2013, the civil rights offices of the Department of Justice and the Department of Education entered into an agreement with the Arcadia Unified School District in California to resolve a complaint against the School District regarding its treatment of a transgender student. $^{394}$ Essentially, the resolution agreement required the School District to recognize the student's gender as he expressed and identified it, rather than as assigned at birth. ${ }^{395}$ The School District agreed to provide to the student "safe and equitable access to all school and District facilities and activities" as a transgender boy, including "sexspecific facilities" such as "restrooms, locker rooms, and overnight

391. Title IX Religious Exemption Database, supra note 12.

392. Trinity International University made its claim in 2003 naming the Evangelical Free Church as its controlling denomination. See Letter from James Manning, Delegated the Auth. of Assistant Sec'y, Office for Civil Rights, U.S. Dep't of Educ., to Gregory L. Waybright, President, Trinity Int'l Univ. (Apr. 27, 2005), http:/www2.ed.gov/about/offices/list/ocr/docs/t9-relexempt/trinity-international-university-response-04272005.pdf. Maranatha Baptist Bible College made its claim in 2012. Letter from Marty Marriott, President, Maranatha Baptist Bible Coll., to Eduardo M. Ochoa, Assistant Sec'y, Office of Postsecondary Educ., U.S. Dep't of Educ. (Feb. 29, 2012), http:/www2.ed.gov/about/offices/list/ocr/docs/t9-rel-exempt/maranatha-baptist-biblecollege-request-02292012.pdf.

393. Title IX Religious Exemption Database, supra note 12.

394. Letter from Anurima Bhargava, Chief, Civil Rights Div., U.S. Dep't of Educ. and Arthur Zeidman, Dir., Office for Civil Rights, U.S. Dep't of Educ., to Joel Shawn, Superintendent, Arcadia $\begin{array}{lllll}\text { Unified Sch. } & \text { Dist. } & \text { 24, 2013), }\end{array}$ https://www.justice.gov/sites/default/files/crt/legacy/2013/07/26/arcadialetter.pdf; $\quad$ ARCADIA RESOLUTION AGREEMENT, supra note 6.

395. See ARCADIA RESOLUTION AgREEMENT, supra note 6, at 1-3. 
facilities." 396 The student's complaint arose because his school refused to fully recognize his gender identity, requiring him to change for gym class in the nurse's office rather than the boy's locker room and assigning him to a separate, individual cabin instead of a boys' group cabin on an overnight camping trip. ${ }^{397}$ Beyond measures for the specific complaining student, the District also agreed to implement changes district-wide including revising its written policies to "specifically include gender-based discrimination as a form of discrimination based on sex," and thus a violation of Title IX, and to define "gender-based discrimination" to include "discrimination based on a student's gender identity, gender expression, gender transition, transgender status, or gender nonconformity." $" 398$ The resolution agreement provided specific definitions of gender identity, gender expression, gender transition, transgender status, and gender non-conformity. ${ }^{399}$ Although the resolution agreement made no specific mention of athletic sports teams, presumably, as with other school services, facilities, and activities, transgender students would participate based on their gender identity rather than assigned gender.

As the Civil Rights Restoration Act had done in 1988 with student health insurance exemption claims, publication of the Arcadia Resolution Agreement caused a flood of new religious exemption action under Title IX. After more than a decade with only two new exemption claims, OCR received ninety new claims in the three-plus years between June 2013 and September 2016, with additional new exemption claims likely. ${ }^{400}$ All but three of those new claims - a claim Liberty University made formally at OCR's request when a student complained regarding abortion, ${ }^{401}$ another claim regarding abortion made by Pontifical Catholic University of Puerto Rico, ${ }^{402}$ and a claim made by Bob Jones University

\footnotetext{
396. Id. at $2-4$.

397. Letter from Anurima Bhargava, Chief, Civil Rights Div., U.S. Dep't of Educ. and Arthur Zeidman, Dir., Office for Civil Rights, U.S. Dep't of Educ., to Joel Shawn, Superintendent, Arcadia $\begin{array}{llllll}\text { Unified } & \text { Sch. } & \text { Dist. } & 2-6 & \text { (July } & \text { 24, }\end{array}$ https://www.justice.gov/sites/default/files/crt/legacy/2013/07/26/arcadialetter.pdf.

398. ARCADiA RESOLUTION AgREEMENT, supra note 6, at 1-6.

399. Id. at $1-2$.

400. Title IX Religious Exemption Database, supra note 12.

401. Letter from Jerry L. Falwell, Jr., Chancellor \& President, Liberty Univ., to Robin C. Murphy, Team Leader, D.C. Office, Office for Civil Rights, U.S. Dep't of Educ. (Jan. 16, 2014), http://www2.ed.gov/about/offices/list/ocr/docs/t9-rel-exempt/liberty-university-request01162014.pdf.

402. Letter from Jorge Iván Vélez Arocho, President, Pontifical Catholic Univ. of P.R., to Catherine E. Lhamon, Assistant Sec'y, Office for Civil Rights, U.S. Dep't of Educ. (May 25, 2016), http://www2.ed.gov/about/offices/list/ocr/docs/t9-rel-exempt/pontifical-catholic-university-of-
} 
regarding male speakers and officials ${ }^{403}$-asserted the religious educational institution's exemption from Title IX to allow it to discriminate based on gender where transgender, gender nonconforming, and in some cases gay individuals were involved. ${ }^{404}$ Simpson University, controlled by the Christian and Missionary Alliance, was the first in October 2013. ${ }^{405}$ A large number of Baptist institutions followed suit, particularly after the Southern Baptist Convention adopted a statement on transgender identity in $2014 .^{406}$ The controlling religious institutions for the ninety claimant institutions range broadly from various Baptist conventions to Friends to Catholic to Churches of Christ to Mennonite Brethren to Methodist to Presbyterian to independent evangelical Christian, although no Jewish educational institutions made new claims. ${ }^{407}$ Forty-one percent of the ninety claims (37/90) specifically cite the Arcadia Resolution Agreement as motivating the new exemption claim. $^{408}$ Just under a third of claimants (27/90) reference the Department of Education's April 2014 Questions and Answers on Title IX and Sexual Violence that expressly included gender identity within Title IX's sex discrimination prohibitions. ${ }^{409}$ Since May 13, 2016, when the Department of Education and Department of Justice issued a joint Dear Colleague Letter on Transgender Students, ${ }^{410}$ six of the thirteen new claims referenced the letter as justification for claiming an exemption. ${ }^{411}$ Repeat players, institutions that had claimed prior

puerto-rico-request-05252016.pdf.

403. Letter from Steve Pettit, President, Bob Jones Univ., to Catherine Lhamon, Assistant Sec'y, Office for Civil Rights, U.S. Dep't of Educ. (Apr. 1, 2016), http://www2.ed.gov/about/offices/list/ocr/docs/t9-rel-exempt/bob-jones-university-request04012016.pdf.

404. Title IX Religious Exemption Database, supra note 12.

405. Letter from Robin Keith Dummer, Interim President, Simpson Univ., to Catherine Lhamon, Assistant Sec'y, Office for Civil Rights, U.S. Dep't of Educ. (Oct. 7, 2013), http://www2.ed.gov/about/offices/list/ocr/docs/t9-rel-exempt/simpson-university-request10072013.pdf.

406. On Transgender Identity, SOUTHERN BAPTIST CONVENTION (2014), http://www.sbc.net/resolutions/2250/on-transgender-identity.

407. Title IX Religious Exemption Database, supra note 12.

408. Id.

409. Id. The April 29, 2014 document Questions and Answers on Title IX and Sexual Violence, which the Department of Education termed "significant guidance," expressly included gender identity as within Title IX's sex discrimination prohibitions. OFFICE FOR CIVIL RIGHTS, U.S. DeP'T of EdUC., Questions AND Answers on Title IX AND SeXual Violence 5-6 (2014), http://www2.ed.gov/about/offices/list/ocr/docs/qa-201404-title-ix.pdf.

410. Catherine E. Lhamon \& Vanita Gupta, Dear Colleague Letter on Transgender Students, U.S. DEP'T EDUC. 1-3 (May 13, 2016), http://www2.ed.gov/about/offices/list/ocr/letters/colleague201605-title-ix-transgender.pdf.

411. Title IX Religious Exemption Database, supra note 12. 
exemptions on other substantive issues in earlier decades, also constituted a third of the claimants (33/90). ${ }^{412}$ As of OCR's September 15, 2016 update to its website, OCR had recognized seventy-two of the ninety claims with the remaining eighteen pending, including at least six requests from OCR to educational institutions for more information regarding their controlling religious organization. ${ }^{413}$ The exemptions OCR recognized for Simpson University, ${ }^{414}$ George Fox University, ${ }^{415}$ and Spring Arbor University ${ }^{416}$ in spring 2014 garnered national attention for religious exemption to Title IX for the first time since the Civil Rights Restoration Act in the late 1980s. ${ }^{417}$

\section{J. Withdrawal of Claims}

In 2016, for the first time, three institutions officially withdrew their long-standing exemption claims, claims that OCR had formally recognized: Pepperdine University, ${ }^{418}$ Loyola University New Orleans, ${ }^{419}$

\footnotetext{
412. Id.

413. Id.

414. Letter from Catherine E. Lhamon, Assistant Sec'y, Office for Civil Rights, U.S. Dep't of Educ., to Robin Keith Dummer, Interim President, Simpson Univ. (May 23, 2014), http://www2.ed.gov/about/offices/list/ocr/docs/t9-rel-exempt/simpson-university-response05232014.pdf.
}

415. Letter from Catherine E. Lhamon, Assistant Sec'y, Office for Civil Rights, U.S. Dep't of Educ., to Robin Baker, President, George Fox Univ. (May 23, 2014), http://www2.ed.gov/about/offices/list/ocr/docs/t9-rel-exempt/george-fox-university-response05232014.pdf.

416. Letter from Catherine E. Lhamon, Assistant Sec'y, Office for Civil Rights, U.S. Dep't of Educ., to Brent Ellis, President, Spring Arbor Univ. (June 27, 2014), http://www2.ed.gov/about/offices/list/ocr/docs/t9-rel-exempt/spring-arbor-university-response06272014.pdf.

417. See, e.g., Erin Buzuvis \& Kristine Newhall, Understanding Religious Exemptions from Title IX, TitLE IX BLOG (July 29, 2014), http://title-ix.blogspot.com/2014/07/understandingreligious-exemptions-from.html; Joshua Hunt \& Richard Pérez-Peña, Housing Dispute Puts Quaker University at Front of Fight over Transgender Issues, N.Y. TIMES (July 24, 2014), http://www.nytimes.com/2014/07/25/us/transgender-student-fights-for-housing-rights-at-george-foxuniversity.html; Scott Jaschik, The Right to Expel, INSIDE HIGHER ED (July 25, 2014), https://www.insidehighered.com/news/2014/07/25/2-christian-colleges-win-title-ix-exemptionsgive-them-right-expel-transgender; Tyler Kingkade, Religious Colleges Are Getting Legal Permission to Discriminate Against Trans Students, HufFington Post (July 28, 2014, 2:21 PM), http://www.huffingtonpost.com/2014/07/28/religious-colleges-trans-students_n_5624139.html.

418. Letter from Andrew K. Benton, President \& CEO, Pepperdine Univ., to Catherine E. Lhamon, Assistant Sec'y, Office for Civil Rights, U.S. Dep't of Educ. (Jan. 27, 2016), http://www2.ed.gov/about/offices/list/ocr/docs/t9-rel-exempt/pepperdine-university-request01272016.pdf.

419. Letter from Kevin Wm. Wildes, President, Loyola Univ. New Orleans, to Catherine E. Lhamon, Assistant Sec'y, Office for Civil Rights, U.S. Dep't of Educ. (May 19, 2016), http://www2.ed.gov/about/offices/list/ocr/docs/t9-rel-exempt/loyola-university-request05192016.pdf. 
and Kettering College of Medical Arts. ${ }^{420}$ All three asserted that their religious organizations continued to exert the requisite control for an exemption, but that other circumstances had changed. Loyola no longer offered student health plans. ${ }^{421}$ Pepperdine had never exercised its 1976 claim and was "committed to complying with Title IX." ${ }^{422}$ Kettering College likewise was committed to Title IX such that it "no longer require[d]" exemption. ${ }^{423}$ All three asked that their names be removed from any lists of institutions claiming religious exemption to Title IX. ${ }^{424}$

\section{APPLiCATION AND ARgument OVER Time}

\section{A. The Control Test Revisited}

In the forty years since the Title IX regulations became effective, not once has OCR found insufficient control by a religious organization to deny an educational institution's claim to religious exemption. Over time, however, the degree of information and depth of argument that educational institutions submit to establish control has increased significantly. No educational institution simply asserts, as St. Charles Borromeo Seminary did in 1976 that a named religious organization controls it or that it is supported and operated by members of the church of Christ, as Harding College did that same year. ${ }^{425}$ Similarly, for exemption claims made since 2012, contradictory evidence suggests that OCR has both relaxed and tightened the control test. On the one hand, OCR no longer makes a factual finding regarding control in its religious exemption disposition letters. On the other, in a change of practice, OCR

420. Letter from Nate Brandstater, President, Kettering Coll. of Medical Arts, to Catherine E. Lhamon, Assistant Sec'y, Office for Civil Rights, U.S. Dep't of Educ. (July 10, 2016), http://www2.ed.gov/about/offices/list/ocr/docs/t9-rel-exempt/kettering-college-of-medical-artsrequest-08182016.pdf.

421. Letter from Kevin Wm. Wildes, President, Loyola Univ. New Orleans, to Catherine E. Lhamon, Assistant Sec'y, Office for Civil Rights, U.S. Dep't of Educ. (May 19, 2016), http://www2.ed.gov/about/offices/list/ocr/docs/t9-rel-exempt/loyola-university-request05192016.pdf.

422. Letter from Andrew K. Benton, President \& CEO, Pepperdine Univ., to Catherine E. Lhamon, Assistant Sec'y, Office for Civil Rights, U.S. Dep't of Educ. (Jan. 27, 2016), http://www2.ed.gov/about/offices/list/ocr/docs/t9-rel-exempt/pepperdine-university-request01272016.pdf.

423. Letter from Nate Brandstater, President, Kettering Coll. of Medical Arts, to Catherine E. Lhamon, Assistant Sec'y, Office for Civil Rights, U.S. Dep't of Educ. (July 10, 2016), http://www2.ed.gov/about/offices/list/ocr/docs/t9-rel-exempt/kettering-college-of-medical-artsrequest-08182016.pdf.

424. See letters cited supra notes 418-20.

425. See supra Sections IV.A.2-3. 
now provides the control test directly to educational institutions when requesting more information. Likewise, in October 2015, OCR published the control test on its website. ${ }^{426}$ OCR itself has claimed continuity in application of the control test for the last thirty years, ${ }^{427}$ although the text of its exemption recognition letters indicates otherwise.

Between 1998 and 2013, as a factual matter, something changed in OCR's consideration of control for purposes of religious exemption to Title IX. $^{428}$ In July 1998, OCR concluded that Brigham Young University-Hawaii "adequately establishe[d]" that it was controlled by a religious organization. ${ }^{429}$ That 1998 communication was the last time OCR drew directly on the standard set forth in the February 1985 Policy Memorandum, the "adequately establishes" language for control, ${ }^{430}$ to find an educational institution eligible for religious exemption to Title IX. Seven years later in less precise, more verbose, language, OCR concluded that the Evangelical Free Church of America controlled Trinity International University:

Your letter and additional information establishes that Trinity is owned and operated by the Evangelical Free Church of America (the Church). Trinity is controlled by the Church and adheres to its religious tenets. Since Trinity is controlled by a religious organization, the regulations that carry out Title IX permit the Department to exempt the institution from requirements of the Title IX regulations where compliance would conflict with the religious tenets of Trinity's controlling religious organization (34 C.F.R. $\S 106.12$ ). Trinity is, therefore, eligible for consideration for an exemption from requirements of the Title IX regulations that conflict with the religious tenets of the Church. ${ }^{431}$

In moving away from the more concise exemption recognition language

426. Office for Civil Rights, Religious Exemption, U.S. DeP'T EduC. (June 30, 2016), http://www2.ed.gov/about/offices/list/ocr/frontpage/pro-students/rel-exempt-pr.html.

427. Email from Seth Galanter, Principal Deputy Assistant Sec'y, Office for Civil Rights, U.S. Dep't of Educ., to author (Sept. 30, 2015) (on file with author).

428. OCR would neither confirm nor deny that a change had occurred in its treatment of control for purposes of religious exemption to Title IX, but stated that the documents speak for themselves. If a change did occur, OCR had no comment on that change. See id.

429. Letter from Norma V. Cantú, Assistant Sec'y, Office for Civil Rights, U.S. Dep't of Educ., to Eric B. Shumway, President, Brigham Young Univ.-Haw. Campus 1 (July 1, 1998), http://www2.ed.gov/about/offices/list/ocr/docs/t9-rel-exempt/brigham-young-university-hawaiiresponse-07011998.pdf.

430. See February 1985 Policy Memorandum, supra note 136, Tab C, Form Letter Two.

431. Letter from James Manning, Delegated the Auth. of Assistant Sec'y, Office for Civil Rights, U.S. Dep't of Educ., to Gregory L. Waybright, President, Trinity Int'l Univ. 2 (Apr. 27, 2005), http://www2.ed.gov/about/offices/list/ocr/docs/t9-rel-exempt/trinity-international-universityresponse-04272005.pdf. 
employed since the Religious Exemption Project, OCR magnified its own authority in the Trinity International letter. OCR claimed that the Title IX regulations permitted it to consider Trinity International's eligibility for exemption when the explicit language of 34 C.F.R. $\S$ 106.12(b) in fact does neither. OCR's language in the 2005 exemption recognition letter approximated the 1974 draft regulation language of request, determination, and qualification ${ }^{432}$ more than the inherent exemption language of the final regulations. ${ }^{433}$

After its rambling letter to Trinity International University in 2005, OCR could have returned to the standard "adequately establishes" language at its next available opportunity, its 2013 exemption recognition letter to Maranatha Baptist Bible College. ${ }^{434}$ It did not. Rather, OCR recited the facts the institution stated, but made no conclusion that the facts established, adequately or otherwise, the required control to claim a religious exemption to Title IX. ${ }^{435}$ Since 2005, OCR has not articulated any finding or conclusion regarding control in any of its exemption recognition letters. Not a single one of the exemption recognition letters OCR issued from 2013 through September 15, 2016, concluded that the educational institution had established the control required to be eligible for a religious exemption. ${ }^{436}$ Even so, OCR has not denied that the requisite control exists, nor has it refused any exemption claims. It simply asks for more information.

In late 2014, OCR requested more information regarding the controlling institutions of Biola University and Colorado Christian University, both of which made exemption claims earlier in $2014 .{ }^{437}$ By September 2016, OCR had done the same to eight other educational

432. See Education Programs and Activities Receiving or Benefiting from Federal Financial Assistance, 39 Fed. Reg. 22228 (proposed June 20, 1974).

433. See supra Section IV.A.

434. Letter from Seth Galanter, Acting Assistant Sec'y, Office for Civil Rights, U.S. Dep't of Educ., to Marty Marriott, President, Maranatha Baptist Bible Coll. (June 19, 2013), http://www2.ed.gov/about/offices/list/ocr/docs/t9-rel-exempt/maranatha-baptist-bible-collegeresponse-06192013.pdf.

435. Id. at 1 .

436. Title IX Religious Exemption Database, supra note 12.

437. See Letter from Seth Galanter, Principal Deputy Assistant Sec'y, Office for Civil Rights, U.S. Dep't of Educ., to Barry H. Corey, President, Biola Univ. (Dec. 22, 2014), http://www2.ed.gov/about/offices/list/ocr/docs/t9-rel-exempt/biola-university-response-

12222014.pdf; Letter from Seth Galanter, Principal Deputy Assistant Sec'y, Office for Civil Rights, U.S. Dep't of Educ., to William L. Armstrong, President, Colo. Christian Univ. (Dec. 5, 2014), http://www2.ed.gov/about/offices/list/ocr/docs/t9-rel-exempt/colorado-christian-university-response12052014.pdf. 
institutions (Arlington Baptist College, Criswell College, Indiana Wesleyan University, The Master's College for Christ and Scripture, Missouri Baptist University, Southeastern University (Florida), Trinity Baptist College, and the University of Dallas) all of whom had made exemption claims in 2015 or $2016 .^{438}$ In contrast to its past practice, OCR included in these information request letters the text of the control test itself. ${ }^{439}$ Thus, all of the universities had before them the control standard by which OCR ostensibly would review the additional factual information they provided, although not the February 1985 Policy Memorandum, nor the October 1988 Memorandum setting forth the degree of deference to the universities' claims. In spring 2016, OCR made public some of the underlying policies and procedures by which it determines religious exemptions to Title IX, posting to its website the February 1985 Policy Memorandum, the August 1985 Agudath compromise letter, the October 1989 memorandum, and the 1977 HEW Form 639-A that outlined the control test. ${ }^{440}$

OCR's request for more information and its inclusion of the control test language is ironic, not just because OCR has not made conclusions regarding the requisite control since at least 2005, but because OCR had

438. See Letter from Seth M. Galanter, Principal Deputy Assistant Sec'y, Office for Civil Rights, U.S. Dep't of Educ., to Charles Bartlett, President, World Baptist Fellowship (May 10, 2016), http://www2.ed.gov/about/offices/list/ocr/docs/t9-rel-exempt/arlington-baptist-collegeresponse-05102016.pdf; Letter from Seth Galanter, Principal Deputy Assistant Sec'y, Office for Civil Rights, U.S. Dep't of Educ., to Barry Creamer, President \& CEO, Criswell Coll. (Jan. 27, 2016), http://www2.ed.gov/about/offices/list/ocr/docs/t9-rel-exempt/criswell-college-response01272016.pdf; Letter from Seth M. Galanter, Principal Deputy Assistant Sec'y, Office for Civil Rights, U.S. Dep't of Educ., to David Wright, President, Ind. Wesleyan Univ. (May 13, 2016), http://www2.ed.gov/about/offices/list/ocr/docs/t9-rel-exempt/indiana-wesleyan-university-response05132016.pdf; Letter from Seth Galanter, Principal Deputy Assistant Sec’y, Office for Civil Rights, U.S. Dep't of Educ., to John MacArthur, President, The Master's Coll. for Christ \& Scripture (Sept. 13, 2016), http://www2.ed.gov/about/offices/list/ocr/docs/t9-rel-exempt/the-masters-collegeresponse-09132016.pdf; Letter from Seth Galanter, Principal Deputy Assistant Sec'y, Office for Civil Rights, U.S. Dep't of Educ., to R. Alton Lacey, President, Mo. Baptist Univ. (Jan. 4, 2016), http://www2.ed.gov/about/offices/list/ocr/docs/t9-rel-exempt/missouri-baptist-university-response01042016.pdf; Letter from Kent J. Ingle, President, Se. Univ., to Seth Galanter, Principal Deputy Assistant Sec'y, Office for Civil Rights, U.S. Dep't of Educ. (Aug. 25, 2016), http://www2.ed.gov/about/offices/list/ocr/docs/t9-rel-exempt/southeastern-university-request08252016.pdf; Letter from Seth Galanter, Principal Deputy Assistant Sec'y, Office for Civil Rights, U.S. Dep't of Educ., to Mac Heavener, Jr., President, Trinity Baptist Coll. (July 22, 2016), http://www2.ed.gov/about/offices/list/ocr/docs/t9-rel-exempt/trinity-baptist-college-response07222016.pdf; Letter from Seth Galanter, Principal Deputy Assistant Sec'y, Office for Civil Rights, U.S. Dep't of Educ., to Thomas W. Keefe, President, Univ. of Dall. (Jan. 8, 2016), http://www2.ed.gov/about/offices/list/ocr/docs/t9-rel-exempt/university-of-dallas-response01082016.pdf.

439. See sources cited supra notes 437-38.

440. Office for Civil Rights, Religious Exemption, U.S. DeP'T EdUC. (June 30, 2016), http://www2.ed.gov/about/offices/list/ocr/frontpage/pro-students/rel-exempt-pr.html?utm_name=. 
previously recognized religious exemptions for four of the ten universities from whom it requested more information regarding control. It had recognized religious exemptions for Biola University, Colorado Christian University, and Indiana Wesleyan University in 1985 as part of the Religious Exemption Project ${ }^{441}$ and for Missouri Baptist University in 1996. ${ }^{442}$ Both Biola University and Missouri Baptist University accompanied their respective exemption claims in 2014 and 2016 with copies of OCR's previous exemption recognition letters from 1985 and $1996 .^{443}$

OCR made no allegation in its requests for more information to Biola University, Colorado Christian University, or Indiana Wesleyan University that the structural organization of the institutions had changed in a way that would undermine OCR's previous determinations that the institutions had "adequately establishe[d]" control by a religious organization for purposes of exemption to Title IX, ${ }^{444}$ nor do the exemption claim letters themselves indicate any changed circumstances regarding organizational structure or control. ${ }^{445}$ In fact, Colorado

441. See November 1985 REP Completion Memorandum, supra note 136, Tab C, at 2, 4; see also supra Section IV.E. Indiana Wesleyan University was previously known as Marion College, the name by which it is listed in the 1985 REP Completion Memorandum. See IWU Story, IND. WESLEYAN UNIV. (Oct. 24, 2016), https://www.indwes.edu/about/iwu-profile/iwu-story.

442. Letter from Susan Bowers, Acting Dir., Policy, Enf't \& Program Serv., Office for Civil Rights, U.S. Dep't of Educ., to R. Alton Lacey, President, Mo. Baptist Coll. (Apr. 18, 1996), http://www2.ed.gov/about/offices/list/ocr/docs/t9-rel-exempt/missouri-baptist-college-response04181996.pdf. Missouri Baptist College became Missouri Baptist University in 2002. History, Mo. BAPTIST UNIV., https://www.mobap.edu/about-mbu/history/ (last visited Oct. 11, 2016).

443. Letter from Barry H. Corey, President, Biola Univ., to Catherine Lhamon, Assistant Sec'y, Office for Civil Rights, U.S. Dep't of Educ. 1 (Nov. 14, 2014), http://www2.ed.gov/about/offices/list/ocr/docs/t9-rel-exempt/biola-university-request-11142014.pdf; Letter from R. Alton Lacey, President, Mo. Baptist Univ., to Catherine Lhamon, Assistant Sec'y, Office for Civil Rights, U.S. Dep't of Educ. 8 n.9 (Mar. 10, 2016), http://www2.ed.gov/about/offices/list/ocr/docs/t9-rel-exempt/missouri-baptist-university-request03102016.pdf.

444. See letters cited supra note 437; Letter from Seth M. Galanter, Principal Deputy Assistant Sec'y, Office for Civil Rights, U.S. Dep't of Educ., to David Wright, President, Ind. Wesleyan Univ. (May 13, 2016), http://www2.ed.gov/about/offices/list/ocr/docs/t9-rel-exempt/indiana-wesleyanuniversity-response-05132016.pdf.

445. See Letter from Barry H. Corey, President, Biola Univ., to Catherine Lhamon, Assistant Sec'y, Office for Civil Rights, U.S. Dep't of Educ. (Nov. 14, 2014), http://www2.ed.gov/about/offices/list/ocr/docs/t9-rel-exempt/biola-university-request-11142014.pdf; Letter from William L. Armstrong, President, Colo. Christian Univ., to Catherine Lhamon, Assistant Sec'y, Office for Civil Rights, U.S. Dep't of Educ. (Nov. 4, 2014), http://www2.ed.gov/about/offices/list/ocr/docs/t9-rel-exempt/colorado-christian-university-request11042014.pdf; Letter from David Wright, President, Ind. Wesleyan Univ., to Catherine Lhamon, Assistant Sec'y, Office for Civil Rights, U.S. Dep't of Educ. (Mar. 18, 2016), http://www2.ed.gov/about/offices/list/ocr/docs/t9-rel-exempt/indiana-wesleyan-university-request03182016.pdf. 
Christian University's 2014 exemption claim provided much more detail regarding Christianity as its controlling commitment than did its 1985 statement, which OCR found adequate to establish control. ${ }^{446}$ The 2014 exemption claim described the University as a "Christ-centered learning community," with all faculty and staff embracing Colorado Christian University's Statement of Faith, and its Board of Trustees adopting "strategic objectives that direct the implementation of the University's consistent mission and vision and provide context for its first priority: an enduring commitment to Jesus Christ and His Kingdom."447 Even so, OCR requested more information, to which Colorado Christian promptly responded in January 2015 with its requirement that faculty and other employees agree, in writing, to the Statement of Faith and strategic objectives. ${ }^{448}$ Likewise, Biola University promptly responded to OCR's request for additional information in February 2015. ${ }^{449}$ After delays between a year and a half and nearly two years, OCR recognized Colorado Christian's exemption claim in June 2016 and Biola's claim in late August 2016. ${ }^{450}$ Indiana Wesleyan University provided additional information regarding control to OCR in June $2016,{ }^{451}$ only a month after OCR made its request. As of the September 15, 2016 update to the OCR

446. Letter from Harry M. Singleton, Assistant Sec'y, Office for Civil Rights, U.S. Dep’t of Educ., to Joe L. Wall, President, Colo. Christian Coll. (Oct. 25, 1985), http://www2.ed.gov/about/offices/list/ocr/docs/t9-rel-exempt/colorado-christian-college-response10251985.pdf.

447. Letter from William L. Armstrong, President, Colo. Christian Univ., to Catherine Lhamon, Assistant Sec'y, Office for Civil Rights, U.S. Dep't of Educ. 1-2 (Nov. 4, 2014), http://www2.ed.gov/about/offices/list/ocr/docs/t9-rel-exempt/colorado-christian-university-request11042014.pdf.

448. Letter from William L. Armstrong, President, Colo. Christian Univ., to Seth Galanter, Principal Deputy Assistant Sec'y, Office for Civil Rights, U.S. Dep't of Educ. (Jan. 6, 2015), http://www2.ed.gov/about/offices/list/ocr/docs/t9-rel-exempt/colorado-christian-university-request01062015.pdf.

449. See Letter from Catherine E. Lhamon, Assistant Sec'y, Office for Civil Rights, U.S. Dep't of Educ., to Barry H. Corey, President, Biola Univ. 1 (Aug. 29, 2016), http://www2.ed.gov/about/offices/list/ocr/docs/t9-rel-exempt/biola-university-response08292016.pdf.

450. Letter from Catherine E. Lhamon, Assistant Sec'y, Office for Civil Rights, U.S. Dep't of Educ., to William L. Armstrong, President, Colo. Christian Univ. 2 (June 28, 2016), http://www2.ed.gov/about/offices/list/ocr/docs/t9-rel-exempt/colorado-christian-university-response06282016.pdf; Letter from Catherine E. Lhamon, Assistant Sec'y, Office for Civil Rights, U.S. Dep't of Educ., to Barry H. Corey, President, Biola Univ. 2 (Aug. 29, 2016), http://www2.ed.gov/about/offices/list/ocr/docs/t9-rel-exempt/biola-university-response08292016.pdf.

451. Letter from David Wright, President, Ind. Wesleyan Univ., to Seth Galanter, Principal Deputy Assistant Sec'y, Office for Civil Rights, U.S. Dep't of Educ. (June 2, 2016), http://www2.ed.gov/about/offices/list/ocr/docs/t9-rel-exempt/indiana-wesleyan-university-request06022016.pdf. 
website, Indiana Wesleyan's claim is pending. ${ }^{452}$

OCR's January 2016 request for information to Missouri Baptist University differed. OCR noted differences between the description of organizational control in the institution's 1996 exemption claim and its 2015 exemption claim. ${ }^{453}$ The 1996 exemption claim used the word "control": the "College is controlled by the Missouri Baptist Convention, and all members of the Board of Trustees of Missouri Baptist College are elected by the Convention." 454 The 2015 exemption claim letter, in contrast, used words like "relationship" and "governed" but not "control":

[T] he University has maintained a close, symbiotic relationship with the Baptist community of believers and is governed by trustees who are members of Baptist churches in Missouri. The [B]oard of $[\mathrm{T}] \mathrm{rustees}$... consists of twenty-seven persons, seventy-five percent $(75 \%)$ of whom are required by the University's Articles of Incorporation to be members of Baptist churches located in Missouri.

Because of the differences between the two exemption claim letters, OCR wrote that it needed additional information "to determine whether the University's relationship with the Missouri Baptist Convention continues to meet the standard for "control"' set forth in the control test. ${ }^{456}$ Missouri Baptist University responded promptly to OCR's query, setting forth the control test and arguing step-by-step, with great factual detail, how it met each of the test's three prongs. ${ }^{457}$ On August 31, 2016,

452. Office for Civil Rights, Religious Exemptions Pending, U.S. DeP'T EdUC. (Sept. 15, 2016), http://www2.ed.gov/about/offices/list/ocr/docs/t9-rel-exempt/rel-exempt-approved-andpending.xlsx.

453. Letter from Seth Galanter, Principal Deputy Assistant Sec'y, Office for Civil Rights, U.S. Dep't of Educ., to R. Alton Lacey, President, Mo. Baptist Univ. 2 (Jan. 4, 2016), http://www2.ed.gov/about/offices/list/ocr/docs/t9-rel-exempt/missouri-baptist-university-response01042016.pdf.

454. Id. at 2 (quoting Letter from Susan Bowers, Acting Dir., Policy, Enf't \& Program Serv., Office for Civil Rights, U.S. Dep't of Educ., to R. Alton Lacey, President, Mo. Baptist Coll. 1 (Apr. 18, 1996), http://www2.ed.gov/about/offices/list/ocr/docs/t9-rel-exempt/missouri-baptist-collegeresponse-04181996.pdf).

455. Id. (quoting Letter from R. Alton Lacey, President, Mo. Baptist Univ., to Catherine Lhamon, Assistant Sec'y, Office for Civil Rights, U.S. Dep't of Educ. 1 (June 18, 2015), http://www2.ed.gov/about/offices/list/ocr/docs/t9-rel-exempt/missouri-baptist-university-request06182015.pdf).

456. Id.

457. Letter from R. Alton Lacey, President, Mo. Baptist Univ., to Catherine Lhamon, Assistant Sec'y, Office for Civil Rights, U.S. Dep't of Educ. 2-5 (Mar. 10, 2016), http://www2.ed.gov/about/offices/list/ocr/docs/t9-rel-exempt/missouri-baptist-university-request03102016.pdf. 
OCR recognized Missouri Baptist University's exemption claim. ${ }^{458}$

The exemption claims of the five other institutions from which OCR requested additional information are in various stages. Criswell College provided additional information and OCR recognized its exemption claim. ${ }^{459}$ Southeastern University provided additional information and awaits OCR's response. ${ }^{460}$ The University of Dallas, Arlington Baptist College, Trinity Baptist College, and The Master's College for Christ and Scripture had not responded to OCR's request for additional information as of September 15, 2016. ${ }^{461}$

Whatever the language of the control test itself, for forty years, it has had basically no substantive content, no limiting effect as applied, despite the explicit statutory language requiring an educational institution to be "controlled by a religious organization" to claim exemption to Title IX. $^{462}$ OCR long accepted any statement of fact-from one of actual control to identification of a particular religion to a commitment to religious principles - as sufficient to evince sufficient control. It would be an abrupt change in policy and practice for OCR to reject the exemption claim of any institution for lack of control by a religious organization, given the numerous exemption claims OCR has recognized under exceptionally minimal definitions of control, including claims by four of the ten institutions from which it has most recently requested additional information. When requesting additional information, OCR has stated that it needs the information "to determine" whether the educational institution's relationship "meets the standard for "control"' in

458. Letter from Catherine E. Lhamon, Assistant Sec'y, Office for Civil Rights, U.S. Dep't of Educ., to R. Alton Lacey, President, Mo. Baptist Univ. 2-3 (Aug. 31, 2016), http://www2.ed.gov/about/offices/list/ocr/docs/t9-rel-exempt/missouri-baptist-university-response08312016.pdf.

459. Letter from Barry Creamer, President \& CEO, Criswell Coll., to Seth Galanter, Principal Deputy Assistant Sec'y, Office for Civil Rights, U.S. Dep't of Educ. (Mar. 22, 2016), http://www2.ed.gov/about/offices/list/ocr/docs/t9-rel-exempt/criswell-college-request-03222016.pdf; Letter from Catherine E. Lhamon, Assistant Sec'y, Office for Civil Rights, U.S. Dep't of Educ., to Barry Creamer, President \& CEO, Criswell Coll. 2 (Aug. 31, 2016), http://www2.ed.gov/about/offices/list/ocr/docs/t9-rel-exempt/criswell-college-response08312016.pdf.

460. Letter from Kent J. Ingle, President, Se. Univ., to Seth Galanter, Principal Deputy Assistant Sec'y, Office for Civil Rights, U.S. Dep't of Educ. (Aug. 25, 2016), http://www2.ed.gov/about/offices/list/ocr/docs/t9-rel-exempt/southeastern-university-request08252016.pdf; see Office for Civil Rights, Religious Exemptions Pending, U.S. DEP'T EDUC. (Sept. 15, 2016), http://www2.ed.gov/about/offices/list/ocr/docs/t9-rel-exempt/rel-exempt-approved-andpending.xlsx.

461. See Office for Civil Rights, Religious Exemptions Index 2009-2016, U.S. DEP’T EDUC. (Sept. 16, 2016), http://www2.ed.gov/about/offices/list/ocr/docs/t9-rel-exempt/z-index-links-list2009-2016.html.

462. 20 U.S.C. § 1681(a)(3) (2012). 
the control test. ${ }^{463}$ Since 2005 , however, OCR has not actually made any determinations of control in the exemption recognition letters it has issued.

For a time, the long delays in recognizing the exemption claims of Biola University and Colorado Christian University suggested that OCR might tighten its factual review under the control test and impose a more rigorous, less deferential standard. In the end, however, OCR did not. OCR has never said "no," not even after making an institution wait nearly two years. Direct confrontation between OCR and religious educational institutions seems unlikely. Even if OCR would prefer to reclaim the control test and impose a more rigorous standard of review, as the requests for information and delays suggested it might, doing so would risk the litigation that OCR and religious institutions have avoided for over forty years.

Moreover, if, over time, the universities from which OCR has requested more information do not respond, OCR need do nothing more. It will have neither granted nor denied the exemption claim and the educational institution likely will continue the practices on which it based its exemption claim in the first place.

\section{B. Inherent Exemption Versus Agency Discretion}

Initially, HEW and OCR used descriptive language that recognized a religious educational institution's inherent exemption to Title IX rather than its own discretion to grant or deny an exemption request. ${ }^{464}$ Beyond OCR's communications with BYU, St. Charles Borromeo Seminary, and Harding College in 1976, the Assurance of Compliance form HEW 639A allowed an educational institution to check a box if it was " $[c]$ laiming a religious exemption under [34 C.F.R. $§ 106.] 12(b) .{ }^{4465}$ In the February 1985 Policy Memorandum, however, OCR replaced the inherent exemption claim language with agency discretion to grant or deny exemption requests. ${ }^{466}$ By doing so, OCR subtly shifted power to itself, even though the standard of review was highly deferential. Moreover, as

\footnotetext{
463. See, e.g., Letter from Seth Galanter, Principal Deputy Assistant Sec'y, Office for Civil Rights, U.S. Dep't of Educ., to Barry Creamer, President \& CEO, Criswell Coll. 2 (Jan. 27, 2016), http://www2.ed.gov/about/offices/list/ocr/docs/t9-rel-exempt/criswell-college-response01272016.pdf.

464. See supra Section IV.A.

465. See, e.g., Assurance of Compliance with Title IX of the Education Amendments of 1972 and the Regulation Issued by the Department of Health, Education, and Welfare in Implementation Thereof from St. Albert's College 2 (June 2, 1977) (emphasis added) (on file with author).

466. See February 1985 Policy Memorandum, supra note 136.
} 
OCR communicated with educational institutions to gather additional information during the Religious Exemption Project, OCR described the educational institutions' actions as requests for religious exemptions rather than claims. ${ }^{467}$ In its exemption disposition letters as well, OCR granted requests. For example, despite a move back towards inherent exemption in OCR's October 1989 policy memorandum, ${ }^{468}$ the language OCR used and continues to use in its disposition letters models agency discretion rather than the educational institution's claim to inherent exemption under the Title IX statute or Constitution. Most recently, in the links on its religious exemption website, OCR identifies the hundreds of claims as "requests" and labels each individual PDF with "request," the educational institution's name, and date. ${ }^{469}$ OCR uses "request" or "requesting" on its religious exemption webpage nine other times. ${ }^{470}$ OCR only uses "claim" three times, all three times referencing the control test or paraphrasing the regulatory procedure language in 34 C.F.R. $\S 106.12$ (b). ${ }^{471}$ The rhetorical shift clearly favors agency discretion rather than inherent exemption.

In fact, the exemption disposition letters OCR has issued in the 2000 s assert an even stronger version of agency discretion regarding religious exemption than in earlier decades. First, the letters accurately cite the statute itself, 20 U.S.C. $\S 1681$, for the general proposition that Title XI prohibits discrimination on the basis of sex. ${ }^{472}$ With respect to religious exemption, however, the letters ignore the specific statutory authority at 20 U.S.C. $\S 1681(a)(3)$ and cite only "[t]he implementing regulation at 34 C.F.R. $\S 106.12, " 473$ as if the agency and the regulations it promulgates, rather than Congress and the statute, afford religious exemption to Title IX. Moreover, the 2000s letters do not distinguish between 34 C.F.R. $\S 106.12$ (a), the regulatory subsection that tracks the substantive language of the statute, and $\S 106.12(\mathrm{~b})$, the regulatory

467. See supra Section IV.E.

468. See supra Section IV.G.2.c.

469. Office for Civil Rights, Religious Exemptions Index 2009-2016, U.S. DEP'T EDUC. (Sept. 16, 2016), http://www2.ed.gov/about/offices/list/ocr/docs/t9-rel-exempt/z-index-links-list-20092016.html.

470. Office for Civil Rights, Religious Exemption, U.S. DEP'T EdUC. (June 30, 2016), http://www2.ed.gov/about/offices/list/ocr/frontpage/pro-students/rel-exempt-pr.html.

471. Id.

472. See, e.g., Letter from Catherine E. Lhamon, Assistant Sec'y, Office for Civil Rights, U.S. Dep't of Educ., to Larry L. Cockrum, Chief Exec. Officer \& President-Elect, Univ. of the Cumberlands, Inc. 1 (Mar. 24, 2015), http://www2.ed.gov/about/offices/list/ocr/docs/t9-relexempt/university-of-the-cumberlands-response-03242015.pdf.

473. See, e.g., id. 
subsection that provides a procedural mechanism for educational institutions to claim exemption. ${ }^{474}$ Rather, the letters state that "educational institutions are allowed to request" exemption to Title IX, as if OCR controls both the initial opportunity for exemption and its ultimate recognition. ${ }^{475}$

Over time, educational institutions have deferred to OCR's arrogation of authority. Educational institutions' use of inherent exemption language - verbs such as claim, notify, establish, assert, inform - in their communications with OCR decreased while their use of language that implied agency discretion-request, apply, seekincreased. Between 1975 and completion of the Religious Exemption Project in November 1985, 64\% of religious educational institutions that did so, claimed religious exemption to Title IX; 18\% requested OCR provide exemption; and another $18 \%$ used both claim and request language. ${ }^{476}$ A goodly portion of the $18 \%$ using both claim and request language made their initial claim in the 1970s and then responded to OCR with request language during the course of the Religious Exemption Project. ${ }^{477}$

From November 1985 through the end of the decade, educational institutions used claim and request language in much closer proportions. Forty percent of educational institutions doing so, claimed religious exemption; 45\% requested religious exemption; and 16\% used both claim and request language. ${ }^{478}$

During the 1990s, the exclusive use of inherent exemption language vanished completely. Not a single educational institution, not even Brigham Young University and its sister LDS educational institutions, relied exclusively on claim language when communicating with OCR regarding religious exemptions to Title IX. ${ }^{479}$ Rather, the LDS educational institutions ( $30 \%$ of the total number) used both claim and request language, while all other institutions $(70 \%$ of the total number),

\footnotetext{
474. See, e.g., id.

475. See, e.g., id. When OCR requests additional information from an educational institution, however, the letter occasionally provides that an educational institution controlled by a religious organization is allowed "to claim" an exemption. See, e.g., Letter from Seth M. Galanter, Principal Deputy Assistant Sec'y, Office for Civil Rights, U.S. Dep't of Educ., to Charles Bartlett, President, World Baptist Fellowship 1 (May 10, 2016), http://www2.ed.gov/about/offices/list/ocr/docs/t9-relexempt/arlington-baptist-college-response-05102016.pdf.

476. Title IX Religious Exemption Database, supra note 12.

477. Id.

478. Id.

479. Id.
} 
relied solely on request language. ${ }^{480}$

In the most recent wave of exemption claims, 2012 through September 15, 2016, six educational institutions (7\%) deployed claim language exclusively. ${ }^{481}$ Harding University made the strongest inherent exemption argument, noting that Title IX itself did not require educational institutions to either submit a formal claim of exemption or to "request approval of exemptions from the Department of Education." 482 Moreover, Harding University did not concede "that Title IX addresses gender identity or sexual orientation," the subject matter on which it claimed exemption, relying in part on Martin Gerry's 1976 letter recognizing the educational institution's prior exemptions: "Title IX does not address the question of homosexuality-it prohibits discrimination based on sex, not actions based upon sexual preference." ${ }^{483}$ In its 2016 exemption claim, Harding University maintained the position it claimed in 1976 and insisted OCR do the same. In contrast to Harding University and the small handful of institutions that used claim language exclusively between 2012 and 2016, 28\% of institutions mixed claim and request language. ${ }^{484}$ In a complete inversion of the 1970s data, in the 2010s, $63 \%$ of educational institutions requested OCR grant religious exemption to Title IX in contrast to the $64 \%$ that claimed exemption in the $1970 \mathrm{~s} .{ }^{485}$

The most dramatic difference between the 1970s and the 2000s is the very limited reliance in the 2000 s on the strongest version of an educational institution's inherent exemption, exclusive reliance on claim, notice, establish, assert, inform, and related verbs in communications with OCR regarding religious exemption. With the exception of a small handful of schools and Harding University in particular, to a significant degree, educational institutions have relinquished their strongest inherent exemption rhetoric and instead now defer to the Office for Civil Rights as the educational institutions request religious exemption to Title IX.

\footnotetext{
480. Id.

481. Id.

482. Letter from Bruce D. McLarty, President, Harding Univ., to Catherine E. Lhamon, Assistant Sec'y, Office for Civil Rights, U.S. Dep't of Educ. 1-2, 10 (May 31, 2016), http://www2.ed.gov/about/offices/list/ocr/docs/t9-rel-exempt/harding-university-request05312016.pdf.

483. Id. at 9-10 (quoting Letter from Martin H. Gerry, Acting Dir., Office for Civil Rights, Dep't of Health, Educ., \& Welfare, to Clifton L. Ganus, Jr., President, Harding Coll. 5 (Oct. 14, 1976), http://www2.ed.gov/about/offices/list/ocr/docs/t9-rel-exempt/harding-university-response10141976.pdf).

484. Title IX Religious Exemption Database, supra note 12.

485. Id.
} 


\section{Constitutional Arguments}

Parallel with the decline of inherent exemption rhetoric, over time, educational institutions have abandoned constitutional arguments in their communications regarding religious exemption to Title IX. Brigham Young University asserted constitutional rights and arguments as it negotiated with government officials the parameters of religious exemption to Title IX in 1975 and $1976 .{ }^{486}$ During the same time frame, a number of other educational institutions also made constitutional arguments against the Title IX regulations in their exemption claim letters. Wheaton College iterated support for the "basic goal of providing equal opportunity for both men and women in education," but expressed concern that the regulations went "beyond the scope and intent" of Title IX and raised "basic constitutional issues under the religious freedom clause of The First Amendment."487 The College would make "[e]very effort" to comply with the regulations but reserved its right "to raise these basic legal issues" if the regulations were applied to it in a way that threatened its core identity. ${ }^{488}$ Five Seventh-day Adventist educational institutions making exemption claims in 1976 stated their position that "the interpretation and implementation of Title IX regulations are subject to constitutional guarantees against unreasonable entanglement with or infringement on the religious teachings and practices of the Seventh-day Adventist Church." ${ }^{489}$ Other institutions found a constitutional violation of religious freedom in the mere existence of Title IX regulations that would allow a federal agency "to determine the validity or non-validity of the religious tenets of a religious body or its private religious educational institution." ${ }^{, 40}$ As discussed above, Orthodox Jewish institutions' insistence on First

486. See supra Section IV.A.1.

487. Letter from Hudson T. Armerding, President, Wheaton Coll., to Martin Gerry, Acting Dir., Office for Civil Rights, Dep't of Health, Educ., \& Welfare 2 (July 20, 1976), http://www2.ed.gov/about/offices/list/ocr/docs/t9-rel-exempt/wheaton-college-request07201976.pdf.

488. Id.

489. Title IX Religious Exemption Database, supra note 12; see, e.g., Letter from Joseph G. Smoot, President, Andrews Univ., to F. David Mathews, Sec'y, Dep't of Health, Educ., \& Welfare 1 (July 15, 1976), http://www2.ed.gov/about/offices/list/ocr/docs/t9-rel-exempt/andrews-universityrequest-07151976.pdf. Other Seventh-day Adventist institutions did not raise constitutional concerns in their 1976 claims.

490. See, e.g., Letter from W. Wilbert Welch, President, Grand Rapids Baptist Coll. \& Seminary, to Office for Civil Rights, U.S. Dep't of Educ. 2 (July 1, 1976), http://www2.ed.gov/about/offices/list/ocr/docs/t9-rel-exempt/grand-rapids-baptist-college-seminaryrequest-07011976.pdf. 
Amendment protections resulted in the Agudath compromise during the Religious Exemption Project. ${ }^{491}$ Through 1992, other institutions raised religious freedom arguments in their claim letters. ${ }^{492}$

Over time, though, like the strongest inherent exemption language, constitutional arguments have almost disappeared from educational institutions' communications with OCR regarding religious exemption to Title IX. In only one of the more than 100 exemption claim communications since 1992 has an educational institution directly raised First Amendment concerns regarding entanglement, infringement, or religious freedom. The sole exception was Liberty University in 2014. At OCR's request after a student filed a complaint, Liberty claimed a religious exemption regarding its disciplinary procedures for abortion. ${ }^{493}$ Liberty University first asserted that its disciplinary policy was nondiscriminatory - it applied to both men and women-but, to the extent OCR interpreted the policy as potentially discriminatory, the policy was founded on religious principles and "must be exempt under Title IX as a permissible exercise under the First Amendment." ${ }^{494}$ OCR granted the exemption. ${ }^{495}$

\section{Statutory and Other Legal Arguments}

Even as institutions backed away from constitutional arguments and inherent exemption language, they increasingly drew on other sources of law or authority-judicial case law, statutes, government agency action or inaction-to justify or inform their religious exemption claim, although it is not clear that such comparative argument influences OCR in its religious exemption determinations. Except for the Civil Rights Restoration Act, OCR has not referenced in its response letters any of the

491. See supra Section IV.E.2.a.i.a).

492. See, e.g., Letter from Thomas E. Corts, President, Samford Univ., to Assistant Sec'y, U.S. Dep't of Educ. 3 (Apr. 29, 1992), http://www2.ed.gov/about/offices/list/ocr/docs/t9-relexempt/samford-university-request-04291992.pdf (stating "[w]e believe that 34 C.F.R. 106.12(a), which enables the religious exemption sought herein, and the First Amendment of the United States Constitution, ensure that Samford should not be subject to such conflicts" between religious tenets and the regulations).

493. See Letter from Jerry L. Falwell, Jr., Chancellor \& President, Liberty Univ., to Robin C. Murphy, Team Leader, D.C. Office, Office for Civil Rights, U.S. Dep't of Educ. 1 (Jan. 16, 2014), http://www2.ed.gov/about/offices/list/ocr/docs/t9-rel-exempt/liberty-university-request01162014.pdf.

494. Id. at 1,3 .

495. Letter from Catherine E. Lhamon, Assistant Sec'y, Office for Civil Rights, U.S. Dep't of Educ., to Jerry L. Falwell, Jr., Chancellor \& President, Liberty Univ. 2 (Apr. 22, 2014), http://www2.ed.gov/about/offices/list/ocr/docs/t9-rel-exempt/liberty-university-response04222014.pdf. 
sources of law or authority that educational institutions have cited to support their exemption claims except as it repeats the institutions' proffered facts. ${ }^{496}$ Educational institutions craft the strongest arguments for exemption they can, but these arguments and efforts may be beside the point given that OCR has never said "no" to a religious exemption claim.

\section{1) Civil Rights Restoration Act}

In the late 1980s and early 1990s, twenty-two institutions cited the Civil Rights Restoration Act (CRRA) as obviating the need to claim a specific exemption to Title IX regulations regarding abortion. ${ }^{497}$ Twenty-one institutions likewise identified the Supreme Court's decision in Grove City College v. Bell as necessitating a religious exemption claim. $^{498}$ Although Grove City College had narrowly interpreted the program or activity language of Title IX and thus limited its application, it also held that a program or activity received federal funds if any of its students received federal financial aid. ${ }^{499}$ While the CRRA overturned the narrow interpretation of program or activity, it left intact the latter interpretation. $^{500}$ Thus, after the CRRA was enacted in 1988, if any student at an educational institution received federal financial aid, the entire institution was a recipient of federal aid for purposes of Title IX, even if that indirect federal aid was the only federal funding the institution received. Colleges and universities recognized the expansion of Title IX coverage almost immediately and filed religious exemption claims accordingly, each institution typically noting its "belie[f] that it may in the past have received, and may currently be receiving, indirect federal aid within [its] understanding of the Supreme Court decision in Grove City College v. Bell, 465 U.S. 555 (1984)."

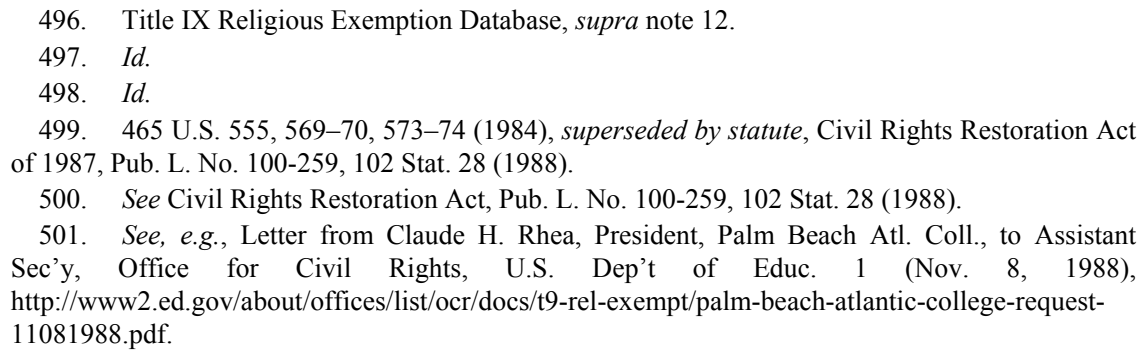




\section{2) Title VII}

In two waves, one in the late 1980s and early 1990s and another beginning in 2014, religious exemption claimants to Title IX analogized to Title VII and judicial interpretation of it. Beginning in 1987 through the early 1990s, twenty-two different educational institutions cited Title VII and the Supreme Court's decision in Corp. of the Presiding Bishop of the Church of Jesus Christ of Latter-day Saints v. Amos ${ }^{502}$ to support their Title IX exemption claims. ${ }^{503}$ Each educational institution "specifically claim[ed] its right to exercise a religious preference in its employment decisions" pursuant to Title VII and Amos. ${ }^{504}$ In an exemption claim in 1997, Brigham Young University explained its understanding of the relationship between Amos, Title VII and religious exemption under Title IX:

Of course, at the heart of [the University's Title IX exemption request] is the holding in Corporation of the Presiding Bishop v. Amos, 483 U.S. 327 (1987), which held that the religious exemptions of Title VII to the Civil Rights Act do not violate the establishment clause of the first amendment [sic]. Simply stated, Amos allows an institution like $\mathrm{BYU}$, one which is owned or controlled by a Church, to exercise a religious hiring preference. That principle, in turn, permits the University to employ Church members who meet certain minimum standards of faithfulness and wholehearted commitment to Church teachings. ${ }^{50}$

Citing Amos was a roundabout way of claiming constitutional justification for religious exemption to Title IX. At least with respect to employees, the argument was that the Supreme Court's finding in Amos - no establishment clause violation in religious exemption to Title $\mathrm{VII}^{506}$ - trumped any potential limitation OCR might impose on religious exemption to Title IX.

Beginning in 2014, a second wave analogized Title VII and Title IX

\footnotetext{
502. 483 U.S. 327 (1987).

503. Title IX Religious Exemption Database, supra note 12.

504. See, e.g., Letter from Gary J. Ridley, President, Alaska Bible Coll., to Assistant Sec'y, Office for Civil Rights, U.S. Dep't of Educ. 3 (Sept. 27, 1988), http://www2.ed.gov/about/offices/list/ocr/docs/t9-rel-exempt/alaska-bible-college-request09271988.pdf.

505. Letter from Merrill J. Bateman, President, Brigham Young Univ., to Norma Cantú, Assistant Sec'y, Office for Civil Rights, U.S. Dep't of Educ. 4 (Aug. 25, 1997), http://www2.ed.gov/about/offices/list/ocr/docs/t9-rel-exempt/brigham-young-university-utahrequest-08251997.pdf.

506. Amos, 483 U.S. at 333-40.
} 
through Killinger v. Samford University, a 1997 Eleventh Circuit Court of Appeals decision regarding control by a religious organization. ${ }^{507}$ In Killinger, the Eleventh Circuit found the relationship between the Alabama Baptist State Convention and Samford University sufficient to exempt the University from Title VII's general prohibition on religious discrimination in employment. ${ }^{508}$ Samford University was "in whole or substantial part, owned, supported, controlled, or managed by a particular religion or religious corporation, association, or society" as Title VII required for exemption. ${ }^{509}$ In Title IX exemption requests to OCR in 2014, 2015, and 2016, at least twenty-one Southern Baptist educational institutions cited Title VII and Killinger as support for control under Title IX. ${ }^{510}$ Their respective Baptist conventions controlled them as the Alabama Baptist State Convention controlled Samford University. Without comment on their analogy or argument, OCR granted the exemption requests.

\section{3) Arcadia Unified School District Resolution Agreement}

As discussed above, a number of educational institutions identified the Arcadia Unified School District Resolution Agreement in 2013, the April 2014 agency document Questions and Answers on Title IX and Sexual Violence, and the May 2016 Dear Colleague Letter on Transgender Students as motivating their exemption claims. ${ }^{511}$ In doing so, the educational institutions pointed out that "the Office for Civil Rights has not issued regulations or guidance" regarding an educational institution's treatment of transgender individuals as students or employees. $^{512}$ In its response letters to these claimants, OCR did not provide any additional guidance regarding transgender or acknowledge that the exemption claimant's interpretation of the Arcadia Resolution Agreement or its own "Questions and Answers" was correct, even for the exemption recognition letters it issued in early 2016 when drafts of the

\footnotetext{
507. 113 F.3d 196 (11th Cir. 1997).

508. Id. at 201.

509. Id. at 200 (quoting 42 U.S.C. $\S 2000 \mathrm{e}-2(\mathrm{e})(2)$ (2012)).

510. Title IX Religious Exemption Database, supra note 12.

511. See supra Section IV.I.

512. See, e.g., Letter from Todd S. Voss, President, S. Wesleyan Univ., to Catherine Lhamon, Assistant Sec'y, Office for Civil Rights, U.S. Dep't of Educ. 2 (Jan. 20, 2015), http://www2.ed.gov/about/offices/list/ocr/docs/t9-rel-exempt/southern-weselyan-university-request01202015.pdf.
} 
May 2016 Dear Colleague Letter on Transgender Students must have been under review. ${ }^{513}$

\section{CONCLUSION}

This analysis is the foundational step in revealing and critiquing the rules and process by which the Office for Civil Rights considers religious exemption claims to Title IX, a power it has arrogated to itself. Over the course of time, transparency and publicity have suffered, although OCR has made significant efforts since December 2015 to provide access to the previously unpublished policy memoranda that have historically guided its exemption determinations. Because the process began and remained entirely administrative, rather than ever-mediated by a judge or jury or otherwise subject to public scrutiny, OCR's policies and practices largely developed without external appraisal or input. Beyond BYU in 1976 and two or three institutions in 2014, application of OCR's policies and practices to individual educational institutions likewise occurred almost entirely outside the public purview until the Human Rights Campaign published its report in December 2015. ${ }^{514}$

With respect to OCR's policies and practices themselves, as applied, the control test has had little substantive content. In the past, almost any statement of fact sufficed for OCR to find the requisite control, even when an institution itself denied control existed. Under the current wave of exemptions, OCR does not appear to be infusing more substance into the control test, particularly given that it no longer makes actual findings regarding control in its exemption recognition letters and routinely recognizes exemptions for institutions that provide additional information regarding control at OCR's request. OCR continues to give significant deference to educational institutions statements of fact regarding control and conflict between religious principles and specific sections of the Title IX regulations, as policy memoranda from the 1980s required.

OCR's administrative practice over time has returned religious exemption to Title IX to the battle fought in 1974 and 1975 over the implementing regulations themselves. The draft regulations allowed OCR's director to "determin[e] whether the institution qualifies" for a

513. See, e.g., Letter from Catherine E. Lhamon, Assistant Sec'y, Office for Civil Rights, U.S. Dep't of Educ., to Todd S. Voss, President, S. Wesleyan Univ. (Mar. 24, 2015), http://www2.ed.gov/about/offices/list/ocr/docs/t9-rel-exempt/southern-weselyan-universityresponse-03242015.pdf.

514. See WARBELOW \& GREGG, supra note 2. 
religious exemption. ${ }^{515}$ The final regulations did not. ${ }^{516}$ Despite the highly deferential standard of review, OCR has arrogated to itself authority, arguably beyond that in either the statute or the final implementing regulations, to review and determine an institution's exemption. Educational institutions have largely, although not completely, acquiesced in that transfer of authority as they have moved away from claiming inherent exemption and making constitutional arguments.

In the end, administrative implementation of religious exemption to Title IX is not how a pluralistic society should structure religious exemption to generally applicable non-discrimination laws. Whether, as a statute, Title IX itself properly accounted for potentially competing values of religious liberty and non-discrimination is another question.

515. Education Programs and Activities Receiving or Benefitting from Federal Financial Assistance, 39 Fed. Reg. 22228, 22234 (proposed June 20, 1974) (codified at 45 C.F.R. pt. 86).

516. 45 C.F.R. $\S 86.12$ (2015); 34 C.F.R. $§ 106.12$ (2015). 